\title{
Trim2 mutant mice as a model for cerebellar ataxia
}

\author{
PhD thesis
}

\author{
in partial fulfillment of the requirements \\ for the degree of Doctor of Philosophy (PhD) \\ in the Graduate Program Neurosciences \\ at the Georg-August University Göttingen \\ Faculty of Biology
}

submitted by

Martin Balastik

born in

Brno, Czech Republic

Göttingen, 2003 
Advisor, first member of FAC: $\quad$ Prof. Dr. Peter Gruss

Second member of FAC: $\quad$ Prof. Dr. Klaus-Armin Nave

Third member of FAC:

Prof. Dr. Wolfgang Engel 
Herewith I declare, that I prepared the $\mathrm{PhD}$ Thesis 'Trim2 mutant mice as a model for cerebellar ataxia' on my own and with no other sources and aids than quoted.

Göttingen, September 22nd, 2003

Martin Balastik 


\subsection{Introduction}

1.1 Functional genomics in the post-genomic era 1

1.1.1 Non-insertional mutagenesis 2

1.1.2 Insertional mutagenesis 3

Gene Trap screening 3

1.2 Cerebellum 8

1.2.1 Cerebellar structure and circuitry $\quad 8$

$\begin{array}{ll}\text { 1.2.2 Cerebellar development } & 12\end{array}$

$\begin{array}{lll}\text { 1.2.3 } & \text { Functional implications of the Cerebellar microcircuitry } & 13\end{array}$

$\begin{array}{ll}\text { 1.2.4 Gait ataxias and cerebellar damage } & 13\end{array}$

$\begin{array}{ll}\text { 1.2.5 Mouse models of cerebellar ataxia } & 15\end{array}$

\begin{tabular}{ll}
1.2 .6 & Ubiquitination pathway \\
\hline
\end{tabular}

\begin{tabular}{ll}
1.3 & RING finger proteins \\
\hline
\end{tabular}

$\begin{array}{lll}2.0 & \text { Results } & 21\end{array}$

2.1 Mouse gene trap line Ei-62 21

2.2 Cloning of the Ei-62 gene 22

2.2.1 RT PCR with degenerated primers 22

2.2.2 Identification of the trapped gene as RING-finger protein TRIM2 24

2.3 Characterization of Trim2 gene with respect to the GT mutation 24

$\begin{array}{lll}2.4 & \text { Trim2 Expression Pattern } & 27\end{array}$

2.4.1 Trim2 expression in the Cerebellum 28

2.4.2 Trim2 expression in the Retina 29

2.4.3 Trim2 expression in the Hippocampus $\quad 29$

2.5 Phenotype of Trim2 ${ }^{\mathrm{GT}}$ mutant mice 30

2.5.1 Genotyping and the primary molecular analysis of the Trim2 ${ }^{\mathrm{GT}}$ mutants 31

2.5.2 Trim2 ${ }^{\mathrm{GT}}$ mutation causes ataxia and tremor in mice 32

2.5.3 Histological analysis of Trim2 ${ }^{\mathrm{GT}}$ mutants 34

Cerebellum $\quad 34$

Retina $\quad 42$

Hippocampus $\quad 43$

Dopaminergic neurons of Substantia Nigra $\quad 44$

2.6 Molecular Analysis of the Trim2 ${ }^{\mathrm{GT}}$ Phenotype 45

2.6.1 Intracellular localization of Trim2 and interaction with Myosin V 46

2.6.2 Electron microscopy of the Cerebellar PC spines 49

$\begin{array}{lll}3.0 & \text { Discussion } & 51\end{array}$

3.1 Gene trap mutagenesis as tool of discovery 51

3.2 Trim2 mutant phenotype shows similar clinical characteristics as human cerebellar $\begin{array}{ll}\text { ataxia syndromes } & 52\end{array}$

3.3 The mutant retina shows a particular kind of degeneration 53

3.4 Despite episodic seizures, the mutant hippocampus is normal 54

3.5 TRIM2 interacts with MyosinV 55

3.6 Mechanisms of neural degeneration: 1) The Trim2-Myosin V-neurofilament connection 
3.7 Mechanisms of neural degeneration: 2) Ubiquitin ligases and neurofilaments as possible originators of neurodegenerative disease $\quad 56$

3.8 Conclusion 57

4.0 Abbreviations and Symbols 58

$\begin{array}{lll}5.0 & \text { Material and Methods } & 62\end{array}$

$\begin{array}{lll}5.1 & \text { Organisms } & 62\end{array}$

$\begin{array}{lll}\text { 5.1.1 Mice } & 62\end{array}$

$\begin{array}{lll}5.1 .2 & \text { Bacterias } & 62\end{array}$

$\begin{array}{lll}5.2 & \text { Material } & 63\end{array}$

$\begin{array}{lll}5.2 .1 & \text { Chemicals } & 63\end{array}$

$\begin{array}{lll}5.2 .2 & \text { Radiochemicals } & 63\end{array}$

$\begin{array}{lll}5.2 .3 & \text { Plastic material } & 63\end{array}$

$\begin{array}{lll}5.2 .4 & \text { Enzymes } & 63\end{array}$

$\begin{array}{lll}\text { 5.2.5 Membranes } & 63\end{array}$

$\begin{array}{lll}5.2 .6 & \text { Films } & 64\end{array}$

$\begin{array}{lll}5.2 .7 & \text { Vectors } & 64\end{array}$

5.2.8 Oligo-desoxy-ribonukleotides $\quad 64$

$\begin{array}{lll}\text { 5.2.9 Antibodies } & 65\end{array}$

5.2.10 Computer analysis $\quad 66$

5.2.11 Media $\quad 66$

$\begin{array}{lll}\text { 5.2.12 Buffers } & 67\end{array}$

5.3 Molecular biology techniques 77

$\begin{array}{lll}\text { 5.3.1 Isolation of the genomic DNA } & 77\end{array}$

$\begin{array}{lll}\text { 5.3.2 Labeling of DNA probe with 32P-a-dCTP } & 77\end{array}$

$\begin{array}{lll}\text { 5.3.3 } & \text { Southern blotting } & 77\end{array}$

$\begin{array}{lll}\text { 5.3.4 Northern blotting } & 78\end{array}$

$\begin{array}{lll}\text { 5.3.5 Screening of E15.5 mouse cDNA library } & 78\end{array}$

$\begin{array}{ll}\text { 5.3.6 Genotyping of the animals } & 81\end{array}$

$\begin{array}{lll}\text { 5.3.7 Western blotting } & 81\end{array}$

$\begin{array}{lll}\text { 5.3.8 } & \text { Pull-down assay } & 83\end{array}$

5.3.9 Coomassie Blue staining $\quad 83$

$\begin{array}{lll}\text { 5.3.10 } & \text { Silver staining } & 84\end{array}$

5.3.11 Fluorescence in situ hybridization (FISH)

5.4 Histology techniques 85

5.4.1 Brain perfusion $\quad 85$

5.4.2 Embedding and sectioning of the fixed tissues $\quad 85$

$\begin{array}{lll}5.4 .3 & \text { b-gal staining } & 86\end{array}$

$\begin{array}{lll}\text { 5.4.4 Immunohistochemistry } & 86\end{array}$

$\begin{array}{lll}\text { 5.4.5 Nissl staining } & 88\end{array}$

$\begin{array}{lll}\text { 5.4.6 Nonradioactive in situ hybridization } & 88\end{array}$

$\begin{array}{lll}\text { 5.4.7 Radioactive in situ hybridization } & 90\end{array}$

$\begin{array}{lll}\text { 5.4.8 TUNEL assay } & 93\end{array}$

$\begin{array}{ll}\text { 5.4.9 Fluoro-jade B staining } & 93\end{array}$

5.5 Cell culture techniques 94

5.5.1 Protein overexpression in Neruo2a (N2a) cell line 94

$\begin{array}{lll}\text { 5.5.2 Protein extraction from cultured N2a cells } & 94\end{array}$

$\begin{array}{lll}\text { 5.5.3 Immunostaining of cultured N2a cells } & 94\end{array}$ 
6.0 References

7.0 Acknowladgements:

107

8.0 Curriculum Vitae

108 


\subsection{Introduction}

\subsection{Functional genomics in the post-genomic era}

With the genome sequences of a large and rapidly growing number of prokaryotic as well as eukaryotic (invertebrate and vertebrate) organisms in hand, Biology is becoming a data-rich science. The major scientific challenge in the "post-genomic era" is thus turning from identifying genes to understanding their function. This is a joint task for geneticists, physiologists, structural and cell biologists and biochemists as well as computer scientists, because knowledge about the function of a gene can emerge only from combining information about expression profile, protein-protein interactions, intracellular localization, structure and in vivo effects of gene mutations. At the same time it is necessary to modify our current techniques so that a large number of genes can be effectively screened and analyzed. This is particularly true for studies focusing on the mammalian central nervous system, because the number of genes involved in neural processes is likely to be large (and largely unknown at this point). 


\section{Introduction}

One of the oldest and most important sources of information for functional genomics, mutagenesis, has been recently adapted for large-scale screens. They can be divided into two groups: non-insertional (use chemical or physical agents as mutagens) or insertional (utilize the mutagenic potential of vector integration into genomic DNA).

The most important results of my $\mathrm{PhD}$ work have been obtained by one large-scale insertional mutagenesis technique, the so-called "Gene Trap Analysis". Therefore, I have to review here, be it briefly, the main features of the gene trap mutation screen utilized in the laboratory of my $\mathrm{PhD}$ Advisor, Prof. Peter Gruss, in order to identify genes involved in the development and function of the mouse central nervous system. My purpose is to give an idea of the method, compare it with other types of mutation screens and discuss its main advantages and limitations.

As it will be seen, Trim2, one of the genes identified and mutated following such screen, and to whose functional analysis most of my $\mathrm{PhD}$ work has been dedicated, turned out to have major importance for the development of the cerebellum. Therefore I will end this introduction by reviewing the main features of cerebellar development, circuitry and function with regard to the functional analysis of Trim2 mutants.

\subsubsection{Non-insertional mutagenesis}

Many important genes have been discovered from analysis of spontaneously aroused mouse mutants. However, the low frequency at which spontaneous mutations occur (ca. $5 \times 10-6$ per locus) makes this approach unusable for any large scale mutation screen. For this reason numerous mutagenic factors were used to increase the mutation rate in mice. The first used X-rays irradiation increases the mutation rate 20 - 100 times but often leads to large deletions and chromosomal translocations, both difficult to control and analyze. Similar multigene mutations can be induced also by application of chlorambucil a chemical agent with even higher mutagenic potential then X-rays (Russell, Hunsicker et al. 1989).

An alternative approach enabling generation of mice carrying random point mutations is the use of ENU (N-ethyl-N-nitrosourea) - highly mutagenic compound that in male mice acts most effectively in spermatogonial stem cells with mutation rates as high as $1.5 \times 10-3$ 


\section{Introduction}

per locus per gamete (Hitotsumachi, Carpenter et al. 1985). Mutagenesis is then followed by entirely phenotype-based screen (Brown and Peters 1996). Even though novel genes can be identified with this method, its major disadvantage still remains that no molecular tag is created at the locus after its mutation. For this reason identification of the mutated gene by positional cloning (Collins 1995) can be a long and cumbersome task. Moreover, since selection is strictly driven by phenotype, recessive lethal mutations are difficult to identify.

\subsubsection{Insertional mutagenesis}

Insertional mutagenesis can be divided into directed and random mutagenesis. Homologous recombination in embryonic stem (ES) cells represents the directed mutagenesis approach and is suitable for inactivation, deletion or subtle mutation of a selected locus (Thomas and Capecchi 1987). Time and resource-consuming work is required here to prepare the targeting construct, to select positive ES cell clones and to reconstitute mice from the selected ES cell clones. The obvious limitation of the method is its suitability for mutation of only already known mouse genes or genes identified in mouse on the basis of sequence similarity to another species.

Finally, Gene Trapping (GT) represents an intersection of the aforementioned mutagenesis approaches: It combines the character of a random screen with the advantages of insertional mutagenesis. The present work (PhD Thesis) is based on the successful application of Gene Trapping techniques.

\subsubsection{Gene Trap screening}

The Basis of gene trapping is introduction of a promoter-less vector into embryonic stem (ES) cells followed by its random integration into an intron, exon or 5'UTR of an expressed gene. This leads to disruption of its wild type RNA transcript and formation of a RNA transcript containing 5'part of the trapped gene fused to transcript of the gene trap vector. (Fig.1) Gene trap vectors contain selection marker (usually neo gene) and reporter gene (usually $\beta$-gal gene) or their fused version (b-geo) but because they contain no promoter, the two genes can not be transcribed unless integration occurs inside a transcription- 


\section{Introduction}

ally active gene. Application of a selective drug as G418 therefore selects only those ES cell clones in which the gene trap vector is being transcribed. Positive ES cell clones are isolated and used for generation of chimeric blastocysts, chimeric mice and finally mutant mouse lines. Thus, the effect of the mutation created can also be studied in vivo.

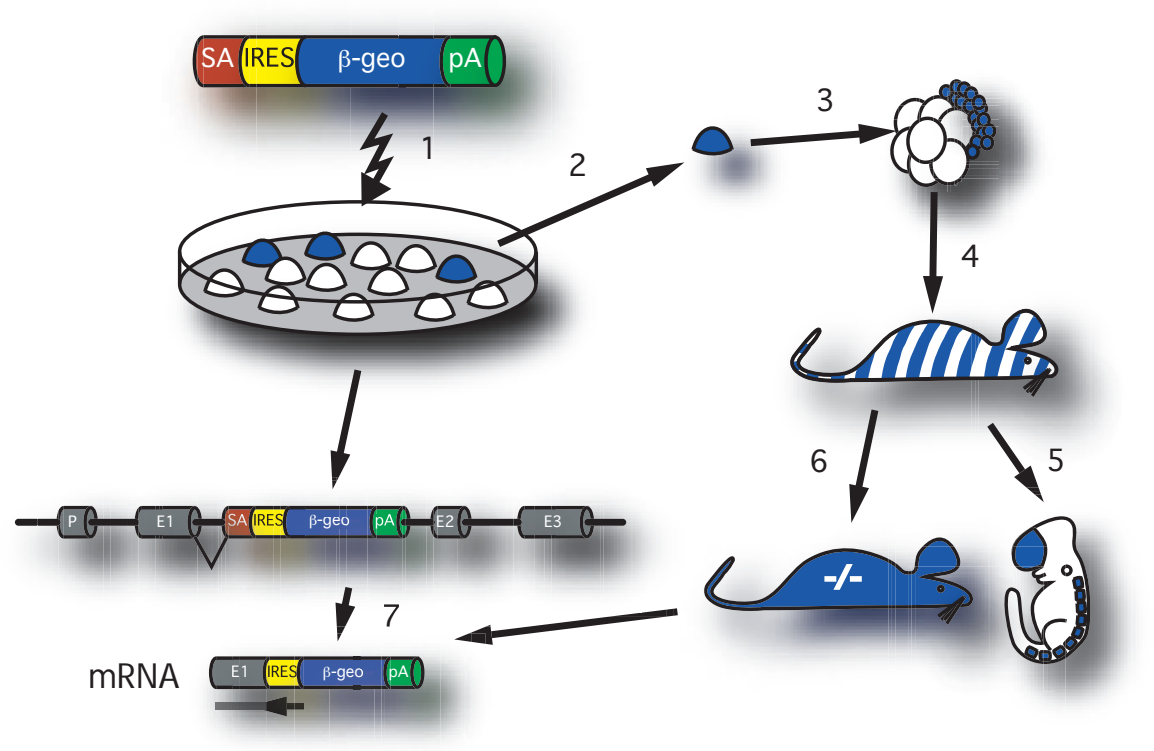

Fig. 1: The main features of the gene trap screen. Promoter-less vector is electroporated into the ES cells (1) and the clones are selected in which integration occurred in a transcriptionaly active gene (2). The selected ES cells are aggregated with a mouse blastocyst (3) and injected into a foster mother for generation of chimeric mice (4). Expression pattern of the trapped gene is evaluated via x-gal staining (5) and phenotype of the mutation is analyzed in homozygous mice (6). The trapped gene is identified by RACE PCR of total RNA (7) isolated either from the ES cells or from tissues expressing the trapped gene in homozygous mice.

Gene trapping evolved from a previous technique called "enhancer trapping", developed to identify and characterize mammalian enhancer sequences from cell lines (Weber, de Villiers et al. 1984). (Fig. 2) Enhancer - trap vectors contain a minimal promoter that requires the vector to insert near to an enhancer to induce expression of the lac $\mathrm{Z}$ reporter gene. Enhancer trapping has not been widely exploited in the mouse since, from the nature of the insertions, loss-of-function mutations are expected to be rare. 


\section{Introduction}

The promoter-less gene trap vectors (GT Vectors) can be divided into two groups based on the mode of the vector DNA delivery into the ES cells. Infection is utilized by retroviral GT Vectors while non-viral vectors are constructed for electroporation of ES cells. Both vector types are similarly effective in creating lineage-restricted expression patterns during mouse embryogenesis and both were shown to have mutagenic potential (Stoykova, Chowdhury et al. 1998; Voss, Thomas et al. 1998; Xiong, Battaglino et al. 1998). Retroviral vectors, though, seem to produce significantly lower percentage of multiple integrations than non-viral GT vectors (Wiles, Vauti et al. 2000).

A

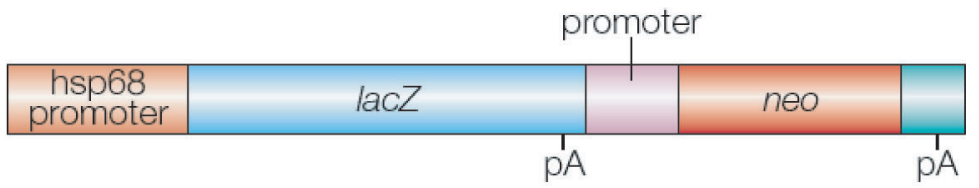

B

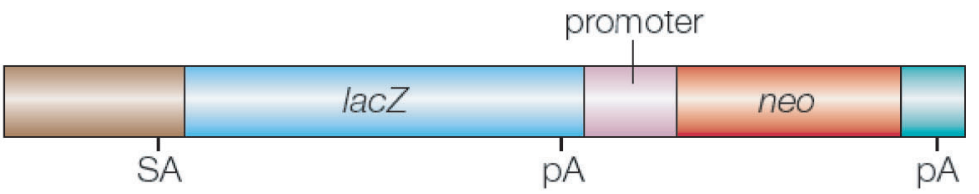

C

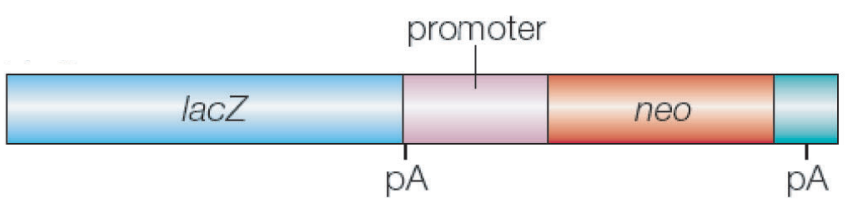

Fig. 2: General structure of the enhancer trap, gene trap and promoter trap vectors. Enhancer trap vectors (A) contain a minimal (e.g. hsp68) promoter in front of a reporter gene (lacZ). The expression of lacZ is enhanced by insertion to a vicinity of an enhancer sequence. (Selection marker, neo, is driven by a constitutive promoter.) Gene trap vectors (B) have splice acceptor site inserted in front of a reporter gene but since no promoter is present in the GT vector, it has to integrate inside an intron of a transcriptionally active gene in order to be transcribed. Promoter trap vectors $(C)$ have neither splice acceptor site nor a promoter requiring an in-frame insertion to occur into an exon sequence. (modified from (Stanford, Cohn et al. 2001))

Structure of the GT vectors may differ also according to the special purpose of the screen. Vectors with promoterless neo gene as a selectable marker have to integrate into a 


\section{Introduction}

gene active in undifferentiated ES cells to provide the resistence to selective drug G418 (Friedrich and Soriano 1991). This, of course, greatly restricts the group of possible target genes. Similarly GT vectors in which expression of selectable neo marker is under a constitutive promoter and is separated from expression of promoterless reporter gene ( $\beta$-gal) allow trapping of even those genes that are transcriptionally inactive in undifferentiated ES cells (Niwa, Araki et al. 1993). In-vitro differentiation of ES cells can be applied to enrich for specific classes of genes (Salminen, Meyer et al. 1998). Thus, modifications of the GT vector can serve as an additional selection criterion to target a particular gene population.

\section{Advantages of the gene trap screen}

There are four main features of the gene trap that make it advantageous when compared to the other mutagenesis screens:

1) Integration of the Gene Trap vector into the mouse genome creates a molecular tag that can be used for identification of the trapped locus. Probably the most straightforward method to achieve this, is RACE-PCR (Rapid amplification of cDNA ends - polymerase chain reaction) (Frohman, Dush et al. 1988). The GT vector sequence is utilized here for priming of the first strand cDNA synthesis of the fusion mutant transcript from total RNA pool. Followed by nested PCR this allows amplification of specific sequence flanking GT vector insertion site. Alternatively, inverse PCR of circularized genomic DNA with GT vector specific primers is suitable for identification of genomic sequence flanking GT vector insertion site (Ochman, Gerber et al. 1988).

2) Given that the integration event is random, gene trap is not limited only to analysis of already known genes - even novel genes can be identified and readily studied. Random integration of the vector into the genomic DNA is an important issue in Gene Trap because the method can be used for large-scale screens only if integration event is stochastic. Even though some integration hot spots in genome, independent of vector type or mode of delivery, were discovered (Evans 1998; Wiles, Vauti et al. 2000), they do not pose a general prob- 


\section{Introduction}

lem for gene trapping since their incidence is relatively low (Chowdhury, Bonaldo et al. 1997).

3) Since GT vectors contain reporter gene (usually $\beta$-gal) it is possible to analyze the expression pattern of the trapped gene by simple $\beta$-gal staining (Friedrich and Soriano 1991). This feature represents another criterion, which enables to select an even unknown gene for further studies based on its restricted expression pattern.

4) Finally, depending on the integration site, disruption of the wild type locus by GT vector insertion leads in many cases to complete or partial inactivation of the trapped gene. This allows studying partial or full knock-out phenotype in mice generated from the selected embryonic stem cell clones.

\section{Limitations of the gene trap screen}

are mainly two:

1) Since disruption of a gene in the 3' part of its coding region or 3' untranslated region (UTR) does not necessarily interfere with its molecular function, sometimes classical homologous recombination mutagenesis is finally necessary to assess the biological role of the trapped gene.

2) It is often the case that, through alternative splicing, the RNA-processing machinery of the cell "bypasses" the inserted Gene Trap Vector, managing to generate a certain amount of full-length wild type transcript (even in the homozygous mutant animals). This is sometimes actually an advantage, since analysis of hypomorphic mutants can be even more useful for functional studies then a null-mutation (particularly when the null-mutants suffer from a severe lethal phenotype). 


\section{Introduction}

\subsection{Cerebellum}

The cerebellum occupies the rostral roof of the 4th ventricle and shares a common structural pattern among vertebrates. Originally assigned, in the beginning of 19th century, to the control of posture and movement, the cerebellum is now considered to play a role in both cognitive and motor processes.

\subsubsection{Cerebellar structure and circuitry}

The great advantage of cerebellum as a model system is its well-defined uniform laminar arrangement of cells, and the equally uniform and well-defined microcircuitry (rev. (Shepherd 1998)).

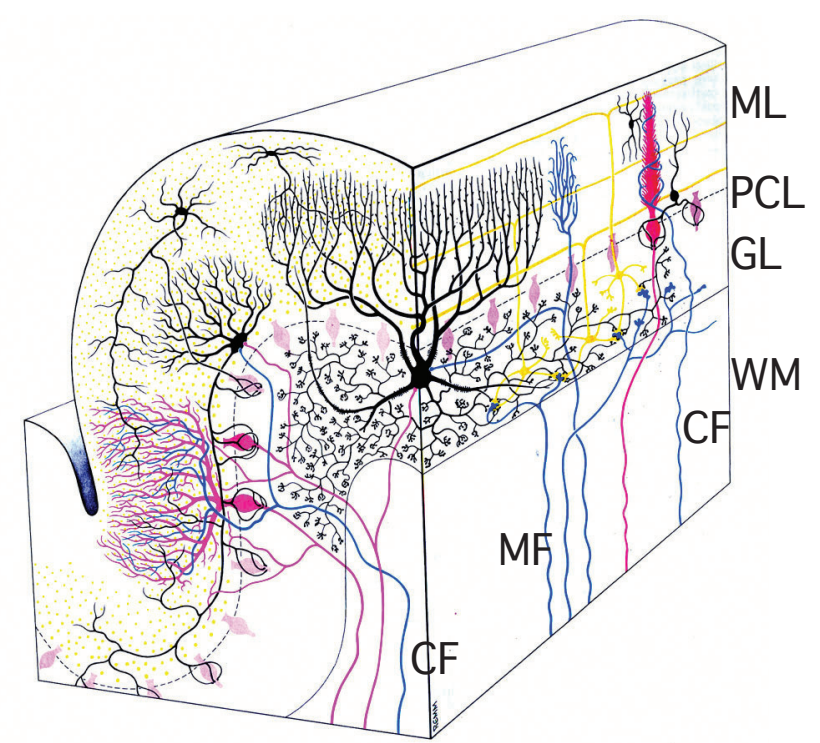

Fig. 3: Structure of the cerebellar cortex. The cerebellar cortex is divided into white matter (WM) and gray matter - subdivided into granule layer (GL), Purkinje cell layer (PCL) and molecular layer (ML). The two kinds of fibers- climbing fibers (CF) and mossy fibers (MF) represent input into the cerebellar cortex while axons of Purkinje cells (red color) are the only output. Mossy fibers innervate granule cells (yellow color) while climbing fibers terminate on Purkinje cells. Three kinds of interneurons (black color) are found in cerebellar cortex: stellate/basket cells in molecular layer and Golgi cells with their cell bodies in GL. (modified from (Williams, Warwick et al. 1989)) 


\section{Introduction}

Cerebellum contains four main types of neurons: Purkinje cells, granule cells, and two kinds of inhibitory interneurons - the Golgi cells and stellate/basket cells. Traditionally, it is divided into two main parts: white and gray matter. (Fig. 3) The white matter is situated inside cerebellum and contains axons of Purkinje cells and mossy and climbing fibers. The gray matter is located on the surface of cerebellum and consists of several layers. The layer closest to the white matter is called granule cell layer. It consists of numerous cell bodies of granule cells and Golgi interneurons. The next - Purkinje cell layer - contains cell bodies of Purkinje neurons. The layer closest to the surface of cerebellum is called molecular layer and it consists of dendrites of Purkinje cells, parallel fibers of granule cells and dispersed stellate/basket interneurons.

There are three kinds of afferent fibers responsible for input into the cerebellum: The mossy fibers originate in the brainstem and the spinal cord; they enter the cerebellum rostrally and make synapses mainly with granule cells. Climbing fibers are projections of inferior olive neurons. They terminate in the Purkinje cell layer and molecular layer making contacts with proximal, smooth branches of Purkinje cells dendrites. One climbing fiber makes multiple synapses to one Purkinje cell. Both mossy and climbing fibers are excitatory. The third kind of afferent connections are diffusely organized mono-aminergic and cholinergic afferents. 


\section{Introduction}

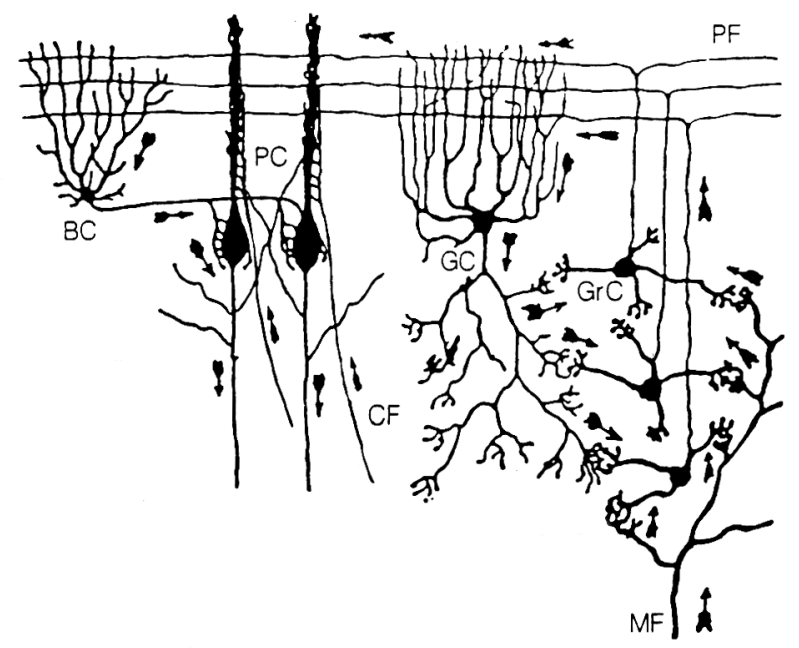

Fig. 4: The microcircuitry of the cerebellar cortex. Inhibitory Purkinje cells receive their excitatory input from climbing fibers $(\mathrm{CF})$ and axons of granule cells $(\mathrm{GrC})$ known as parallel fibers (PF). Granule cells are themselves stimulated by mossy fibers (MF). Basket cells (BC) provide an inhibitory feedback to PC while Golgi cells (GC) negatively regulate GrC. (modified from (Shepherd 1998)).

Glutamatergic cerebellar granule cells are the most numerous neurons of the CNS. They receive input from mossy fibers and send their unmyelinated axons into the molecular layer where they bifurcate and as "parallel fibers" make connections with many Purkinje neurons in the distal part of their dendritic trees.

Inhibitory (GABAergic) Purkinje cells are the only principal neurons of cerebellum and serve as the only output of the cerebellar cortex. They have a characteristic shape with large nucleus and huge flattened dendritic tree, perpendicular to the parallel fibers, where numerous synapses with climbing and parallel fibers are made. Their myelinated axons terminate in the deep cerebellar and vestibular nuclei and certain brainstem nuclei.

There are two kinds of interneurons in cerebellum providing feedback for granule cells (Golgi cells) and Purkinje neurons (stellate/basket cells). Golgi cells are found in the granular layer and they express both GABA and glycine. Stellate/basket cells are purely GABAergic and they are spread in molecular and Purkinje cell layers (Fig.4). 


\section{Introduction}

All the climbing fibers that innervate Purkinje cells originate in the inferior olive. Beside the climbing fibers olivary neurons send collaterals to the deep cerebellar nuclei (DCN), which are also the main target of the inhibitory projections of Purkinje cells. Since DCN send their inhibitory axons directly to those olivary subnuclei from which they receive excitatory collaterals the whole olivo-cerebellar circuitry has a form of a regulatory loop. (Fig.5)

Another three-elements loop superimposed on the olivo-cerebellar system is the olivocerebellar mesodiencephalic loop. It is formed by the projections from the olivary collaterals to the cerebellar nuclei, from the cerebellar nuclei to the mesodiencephalic junction, and from the mesodiencephalic junction back to the inferior olive. The whole loop is excitatory being controlled by local inhibitory interneurons, by inhibitory collaterals from the cerebellar nuclei to the inferior olive and by Purkinje cell projections.

Mesodiencephalic junction consists of variety of nuclei some of which project directly to motoneurons and interneurons in the spinal cord influencing motor acitivity.

Functional implications of the two tightly regulated loops will be discussed later.

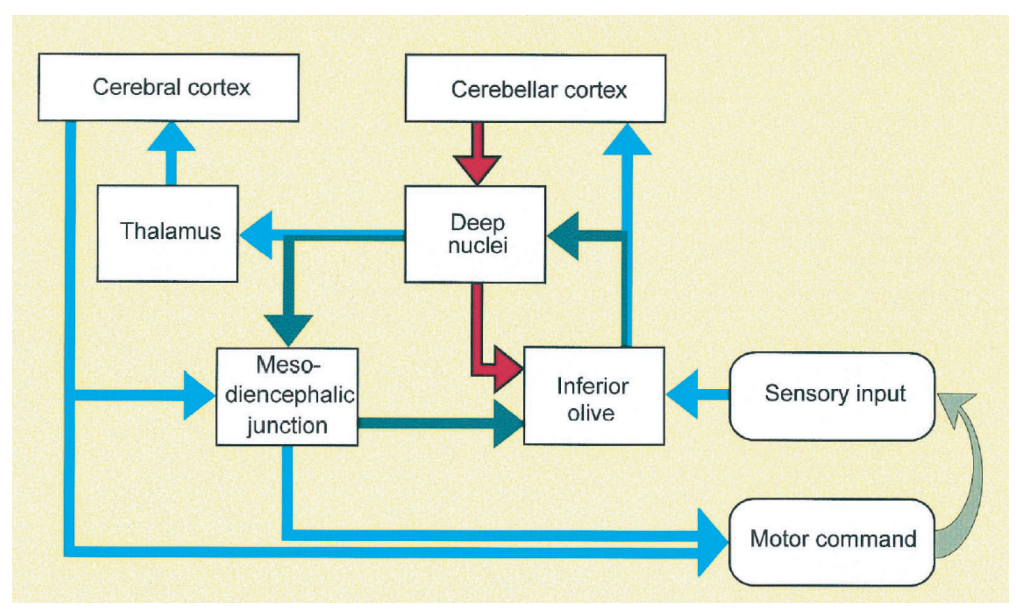

Fig. 5: Olivocerebellar mesodiencephalic loop. Red arrows symbolize inhibitory and blue arrows excitatory projections. (from (De Zeeuw, Simpson et al. 1998)) 


\section{Introduction}

\subsubsection{Cerebellar development}

The cerebellum derives from the dorsal plate of the neural tube. The germinal matrix that gives rise to all cerebellar neurons consists of neuroepithelial ventricular zone and more caudal rhombic lip. Originally single, germinal matrix subsequently divides in two different germinal zones. Thus, unlike most of the other parts of the CNS, cerebellar neurons arise from at least two different germinal zones. (rev. (Altman and Bayer 1997))

The first neurons generated from the ventricular zone are neurons that later form deep cerebellar nuclei (day E10-12 of mouse embryonic development) soon followed by Purkinje cells (E11-13). After those cells stop dividing, cells of the rhombic lip start to migrate over the cerebellar surface, ultimately forming secondary germinal matrix - the external granular layer (EGL). In the same time Golgi interneurons are born in the ventricular zone

The other cerebellar interneurons residing in the molecular layer - stellate and basket cells - were originally thought to be generated simply from the EGL. Currently, though, the whole process is considered to occur two steps. The original generation takes place in the ventricular layer, the newly born cells are migrating to the white matter where they further divide and finally move to the molecular layer (Zhang and Goldman 1996).

Postnatally the granule cell neuroblasts present in the EGL migrate inward radially through the molecular and Purkinje cell layers (probably with the help of radial Bergman glia fibers) towards the internal granular layer. The whole process is finished by the end of the third postnatal week when the EGL does not exist any more and two major inputs into cerebellum - mossy and climbing fibers - are established. During postnatal development cerebellum increases its volume ca. 1000 times and gains its characteristic foliated shape.

Cerebellar development is very tightly regulated not only by the exact spatiotemporal coordination of cell division and migration, even the ratio of Purkinje to granule cells seems to be strictly controlled. Analysis of numerous mutations as well as experimental perturbations demonstrate that elimination of Purkinje cells is usually followed by reduction of the granule cell population (Feddersen, Ehlenfeldt et al. 1992; Herrup and Kuemerle 1997). Besides, Purkinje cells can control the number of granule cells already in the EGL by regulating their mitotic activity (Smeyne, Chu et al. 1995). Moreover, a certain low level of cell 


\section{Introduction}

death was detected in developing EGL suggesting cell death could also be involved in regulation of granule cell number (Smeyne and Goldowitz 1989). The inverse regulation of number of Purkinje cells via granule cell number seems also to exist even though Purkinje cell death as a developmental mechanism is much less common (Norman, Feng et al. 1995; Zanjani, Vogel et al. 1996).

\subsubsection{Functional implications of the Cerebellar microcircuitry}

Several hypotheses have been proposed to explain cerebellar function in regard to its microcircuitry. They emphasize important role of the olivocerebellar mesodiencephalic loop for cerebellar function. Currently two proposed roles of the cerebellum are gaining major support.

According to the first hypothesis the cerebellum is responsible for appropriate timing of command signals for motor domains (Welsh, Lang et al. 1995). It is based on the finding that olivary neurons can fire rhythmically and that initiation and performance of movements is correlated with synchronous activity of olivary neurons electronically coupled by gap junctions (rev. (De Zeeuw, Simpson et al. 1998)).

The second hypothesis considers motor learning as the most important cerebellar function (Ito 1982). It states that Purkinje cells receive error signals indicating inadequate motor activity from inferior olive via climbing fibers. Climbing fibers input evokes a complex spike activity that leads to a long-term depression of single spike response triggered by the parallel fibers. By this means, the olivocerebellar mesodiencephalic loop can control and correct motor performance.

\subsubsection{Gait ataxias and cerebellar damage}

Our knowledge of cerebellar function comes mainly from analysis of the effect of cerebellar damage either mechanical or degenerative. The most common sign of cerebellar dysfunction are gait ataxias generally defined as unsteadiness of walking that result from degeneration or damage of cerebellum and its afferent and efferent connections. Another 


\section{Introduction}

symptoms often associated with ataxias are lack of coordination, tremor, dysmetria and muscular hypotonia.

Ataxias can be caused by variety of factors: from developmental malformations, cerebellar infarction, neoplasms, viral infections, lesions and alcohol abuse in case of nonhereditary ataxias, to mutations in various genes in the case of hereditary ataxias. Hereditary ataxias have been known for more then a century; still, it was not until recently when first genes responsible for the condition were identified. Not surprisingly, several kind of ataxias previously joined in one group based on their clinical diagnoses appeared to have very different molecular bases indicating ataxias are suggestive of a cerebellar defect on cellular rather then molecular level. It is important to remember that, as disturbances of cerebellar cortex where Purkinje cells are the only principal neurons, ataxias eventually concern function or number of Purkinje cells or both.

Classical genetics classified hereditary ataxias as dominant or recessive.

Friedrich's ataxia is the most common type of recessive hereditary ataxia. It is characterized by degeneration in dorsal root ganglia neurons, spinocerebellar, posterior column, pyramidal tract and in cerebellum (rev. (Klockgether and Evert 1998)). In the vast majority of Friedrich's ataxia patients the cause of the disease was identified as an expansion of GAA repeats inside an intron sequence of a gene frataxin (Campuzano, Montermini et al. 1996). Frataxin is a mitochondrial protein involved in iron metabolism (Foury and Cazzalini 1997). The exact effect of GAA repeats is not known, yet. In theory they can affect frataxin mRNA stability, splicing or transcription resulting in decrease of its expression and, subsequently, higher risk of oxidative stress leading to neurodegeneration.

Expansion of trinucleotide repeats causes also some of the dominant hereditary ataxias known as spinocerebellar ataxia (SCA), characterized by loss of Purkinje cells and additional pathological changes in spinal cord, brainstem, retina and peripheral nervous system (Klockgether, Wullner et al. 2000). Genetic analysis revealed that mutation in at least eight different genes could result in SCA. The coding region of most of the SCA genes contains 


\section{Introduction}

few CAG repeats coding for glutamine. In the SCA patients the number of CAG repeats is greatly increased and usually unstable with a tendency to a further expansion during cell division, particularly meiosis (Chong, McCall et al. 1995). Since number of CAG repeats has a direct effect on the onset of disease, subsequent generations usually suffer from even earlier onset of the condition. A common feature of the polyglutamine diseases possibly involved in the pathology is presence of intranuclear inclusions in the affected tissues (Paulson, Perez et al. 1997). The molecular mechanism of CAG repeat pathology itself, though, is still unknown.

Channelopathies are group of dominant hereditary ataxias, caused by mutations in genes coding for ion channels. At least two ion channels - brain $\mathrm{K}+$ channel gene KCNA1 (Browne, Gancher et al. 1994) and $\alpha 1 \mathrm{~A}$ voltage dependent $\mathrm{Ca}^{2+}$ channel subunit CACNL1A4 (Ophoff, Terwindt et al. 1996) - were linked to dominant hereditary ataxias in human. Nature of the mutation plays an important role in the final phenotype. Thus, a deletion in CACNL1A4 gene leads to episodic ataxia type 2 (Ophoff, Terwindt et al. 1996), while expansion of CAG repeats in the 3' end of the same gene results in spinocerebellar ataxia type 6 (Zhuchenko, Bailey et al. 1997).

\subsubsection{Mouse models of cerebellar ataxia}

Most of the information about molecular basis of ataxias came from analysis of mouse cerebellar mutants. Aside from already mentioned ion channels KCNA1 and CACNL1A4, which were found in human and later characterized in mouse (Fletcher, Lutz et al. 1996; Smart, Lopantsev et al. 1998), several other ion channels were discovered or linked to ataxias through analysis of natural mouse cerebellar mutants.

Mutation in G-protein-dependent inwardly rectifying potassium channel protein GIRK2 was found in weaver mutant mice (Patil, Cox et al. 1995) causing almost complete loss of vermal and paravermal granule cells in the EGL. The mutation affects secondarily Purkinje cells leading to changes in their arborization, spatial orientation of their dendritic tree and ca. 25\% degeneration (Rezai and Yoon 1972). Of course, mutant mice suffer from severe ataxias, tremor and poor limb conditions. 


\section{Introduction}

Semi-dominant Lurcher mutation resulting in virtually complete absence of Purkinje cells in heterozygous Lc/+ mutants, was shown to affect an ionotropic glutamate receptor delta-2 GRID2 (Zuo, De Jager et al. 1997). The secondary effect of Purkinje cell death affects here both granule cells and inferior olivary neurons ending up in their partial degeneration (De Jager and Heintz 1998).

In addition to the ion channels or ionotrophic receptors, mutations in metabotrophic receptors present in Purkinje cell synapses can also promote cerebellar damage and ataxia. Null mutation of metabotrophic glutamate receptor mGluR1 strongly expressed in Purkinje cells results in ataxic phenotype in mouse even without any obvious histological defect (Aiba, Kano et al. 1994).

Prominent role of synaptic proteins for maintenance of cerebellar homeostasis is demonstrated by another spontaneous recessive mouse mutant - "ataxia" (ax/ax). The mutation was recently characterized as transposon insertion to ubiquitin-specific protease 14 (Usp14) (Wilson, Bhattacharyya et al. 2002). Even though the mutant mice suffer from severe tremor followed by hindlimb paralysis and death by 6-10 weeks of age, neither cell loss, nor any ubiquitin positive protein aggregates were ever detected in the CNS of the mutant mice. The only defect detected was a subtle abnormality in the synaptic transmission residing in the presynaptic side of the synapse.

The molecular function of several other genes involved in cerebellar degeneration and ataxia like Nna1, recently shown to be mutated in classical PCD (Purkinje cell degeneration) mutants (Fernandez-Gonzalez, La Spada et al. 2002), still needs to be elucidated.

The increasing number of ataxic mutants with a mutation inside a synaptic protein, though, indicates that synaptic transmission is a particularly vulnerable process where even a slight deregulation can result in damage of the whole cerebellar circuitry. Particularly one regulatory mechanism - ubiquitination - seems to play a key role in keeping neuronal homeostasis. Not only many neurological mouse models have mutation in a member of ubiquitination complex and ubiquitin-positive protein aggregates are hallmarks of most of neurodegenerative diseases, defects in ubiquitination machinery were already found to cause neurological syndromes in human, too (rev. (Chung, Dawson et al. 2001)). 


\section{Introduction}

\subsubsection{Ubiquitination pathway}

The ubiquitination pathway is a multistep process that involves at least three different enzyme types known as E1 (ubiquitin activating enzyme), E2 (ubiquitin conjugating enzyme) and E3 (ubiquitin ligase). In a chain of reactions ubiquitination machinery brings together activated ubiquitin and selected protein to be ubiquitinated and transfers the ubiquitin to the protein. Polyubiquitinated protein is then recognized by proteasome and degraded (Joazeiro and Weissman 2000; Weissman 2001).

Very interesting, and up to now still not entirely understood, regulatory pathway is triggered by monoubiquitination of a protein (rev. (Hicke 2001)). Unlike polyubiquitination it does not seem to cause protein degradation in proteasome but rather to have a regulatory effect. Monoubiquitination of some ion channels (Staub, Gautschi et al. 1997) and receptors (Strous, van Kerkhof et al. 1996) thus induces their internalization and subsequent degradation in the lysosome pointing at a close relation of ubiquitin and intracellular transport systems (Hicke 1999).

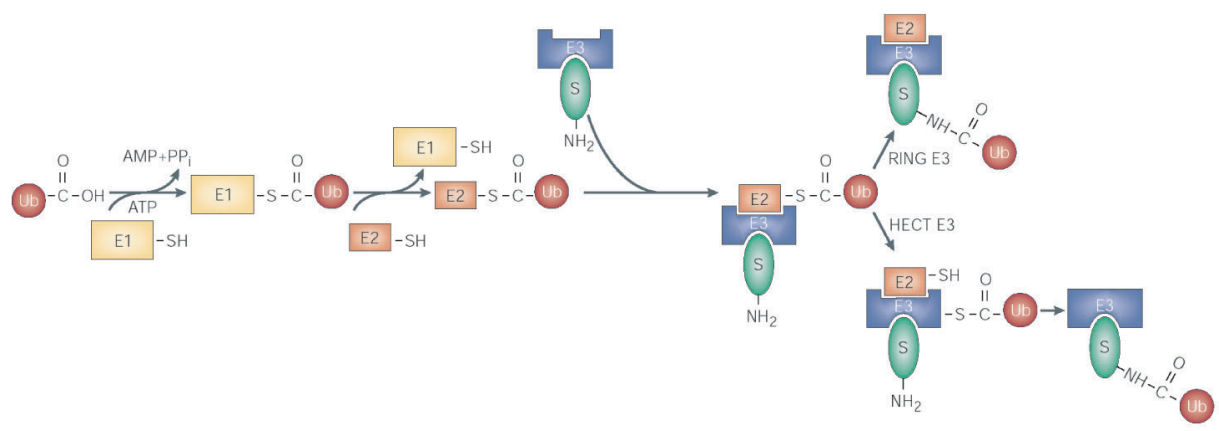

Fig. 6: The ubiquitination pathway. Ubiguitin is activated by forming a thioester bond with ubiquitin activating enzyme (E1), transfered to ubiquitin conjugating enzyme (E2) and finally with help of an ubiquitin ligase (E3) bound either directly (RING finger E3) or indirectly (through an intermediate bond to HECT E3) to a lysine residue of a protein targeted for proteasomal degradation. (modified from (Weissman 2001)). 


\section{Introduction}

Out of the enzymes involved in the ubiquitination cascade, the so-called "ubiquitin activating enzymes" are the least numerous (Fig.6). They activate ubiquitin by forming a thioester bond in an ATP-dependent process. The activated ubiquitin is then transferred to ubiquitin-conjugating enzyme by a trans-thiolation reaction. The final transfer to the lysine residue of a target protein is catalyzed by one of ubiquitin ligases. Two main families of ubiquitin ligases have been identified up to now. HECT domain containing E3s, the first group, form themselves an intermediate thioester bond with ubiquitin. The second group RING finger proteins - is sometimes considered to mediate direct transfer of ubiquitin to a target protein, but for known diversity of the RING finger protein family, more information is needed to draw the final conclusion. (Jackson, Eldridge et al. 2000) 


\section{Introduction}

\subsection{RING finger proteins}

The RING finger motif gained its name from the protein where it was described for the first time - RING1 (for Really Interesting New Gene 1) (Lovering, Hanson et al. 1993). Since then the family has grown rapidly and till today hundreds of RING finger proteins have been already identified in various eukaryotes, but interestingly in no prokaryote protein (Saurin, Borden et al. 1996).

RING finger motif belongs to the group of Cys/His zinc finger proteins with consensus sequence defined as: Cys-X(2)-Cys-X(9-39)-Cys-X(1-3)-His-X(2-3)-Cyx/His-X(2)Cys-X(4-48)-Cys-X(2)-Cys where $X$ can be any amino acid. RING finger motif, like the other zinc motifs, binds two zinc atoms. Its secondary cross-brace structure (Fig.7), though, is unique of RING fingers (rev. (Borden and Freemont 1996)).

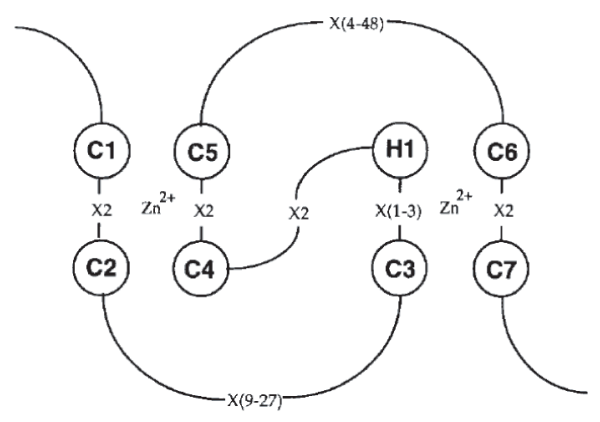

Fig. 7: The conserved "cross-brace" secondary structure of the RING finger domain. (Borden and Freemont 1996)

RING finger domain is often associated with one or two other zinc-binding motifs called B-box and followed by a leucine coiled-coil domain. The whole structure is called RBCC or Tripartite motif and specifies the TRIM or RBCC subfamily of RING fingers rev. (Saurin, Borden et al. 1996). All the three domains are considered to mediate protein-protein interactions; interaction with DNA has not been demonstrated, yet. The TRIM subfamily of RING fingers consists now of at least 37 members, majority with multiple splice 


\section{Introduction}

isoforms (Reymond, Meroni et al. 2001). Although structurally defined, what is the functional link between members of the TRIM subfamily is still unclear. Several TRIMs were either directly or indirectly linked to human disease emphasizing the significance of the subfamily (Goddard, Borrow et al. 1991; Niikura, Hashimoto et al. 2003).

Ever since it was discovered, the RING finger motif has been a matter of speculations over its cellular function. With hundreds of RING finger proteins now identified the problem seems to be even more complex since RING finger proteins were found to be involved in variety of different cellular processes including development, transformation, apoptosis, viral replication or neurodegeneration. In several cases their dysfunction seems to have a deleterious effect for the whole organism. Point mutations within the RING finger of BRCA1 gene, for instance, create a predisposition to breast cancer for females (Miki, Swensen et al. 1994). Mutation in PML gene indicate a higher risk of promyelocytic leukaemia (Goddard, Borrow et al. 1991), Mel18 mutation was identified in human melanoma (Kanno, Hasegawa et al. 1995) and mutant parkin protein is a cause of juvenile form of autosomal recessive familial Parkinsonism (Shimura, Hattori et al. 2000).

With such a diversity of cellular processes it was originally thought, the only common function of RING finger domain was to mediate protein - protein interactions and to form large macromolecular scaffolds. The situation has changed recently with discovery that RING finger domain can interact with components of ubiquitination pathway. Since then function of many RING fingers has been revised and linked to ubiquitination.

Importantly, the already mentioned diversity of processes RING finger proteins are involved in could easily be explained by their role in ubiquitination. As ubiquitination regulates virtually all cellular processes the same would be true for the RING finger proteins. The TRIM subfamily or RING fingers has been recently linked to ubiquitination, too, (Toniato, Chen et al. 2002; Niikura, Hashimoto et al. 2003; Xu, Yang et al. 2003) suggesting RING finger motif itself is required for the interaction with ubiquitination complex.

Whether ubiquitination is the main function of all RING finger proteins or only some of them is still an unanswered question. 


\section{Results}

\subsection{Results}

\subsection{Mouse gene trap line Ei-62}

In order to search for novel genes involved in regulation of development and function of the Central Nervous System, a large-scale mouse Gene Trap (GT) screening was performed by the research group of Prof. Peter Gruss. This project generated as expected hundreds of novel GT stem cell clones. Chimeric mice were made out of selected stem cell clones and basic information about their expression pattern in mouse (obtained through $\beta$ gal staining of the chimeric and heterozygous embryos) and a partial sequence of the trapped gene (obtained via RACE PCR) were collected in the mouse GT library (https:// gwdu64.gwdg.de/pls/w/key_search\$.startup). The library provides basic criteria for choosing a particular mouse line for a more detailed genetic and molecular characterization.

Mouse gene trap line Ei-62 was chosen for further analysis based on its restricted expression pattern in developing central nervous system (Fig. 8) suggesting a role in the development and/or function of the CNS. The 5' RACE PCR amplification of cDNA 5' adjacent to the GT vector insertion site resulted in cloning of a $370 \mathrm{bp}$ sequence (Pires da 


\section{Results}

Silva 1999) showing the highest similarity ( $86 \%$ identity) to a human est clone KIAA0517 as revealed by screening of gene bank database at http://www.ncbi.nlm.nih.gov.

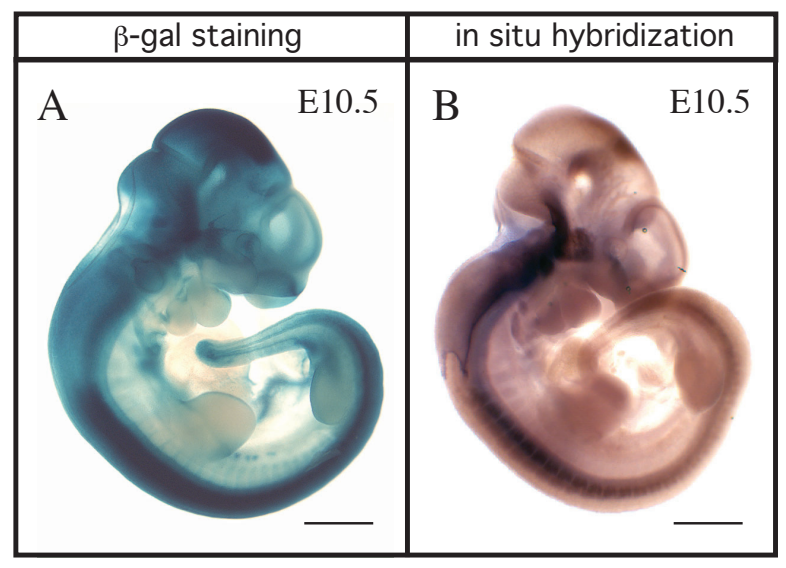

Fig. 8: Expression pattern of the Ei-62 mouse gene trap line at the embryonic day E10.5 visualized by $\beta$-gal staining (A). The strongest expression was detected in spinal cord, dorsal root ganglia, midbrain, hindbrain and trigeminal ganglia. The same pattern of expression was obtained by whole mount in situ hybridization with Trim2 1.1 probe (B). Scale bars: $1.5 \mathrm{~mm}$

\subsection{Cloning of the Ei-62 gene}

\subsubsection{RT PCR with degenerated primers}

A computer search at http://www.ncbi.nlm.nih.gov for genes with highest degree of similarity to the KIAA0517 clone revealed existence of a rat protein called BERP (Brain expressed RING finger protein) $67 \%$ identical to KIAA0517 on amino acid level (Fig. 9). Based on nucleotide similarity between human est clone KIAA0517, rat gene BERP and mouse Ei-62 clone, Ei-62 clone seemed to be the mouse orthologue of human KIAA0517 gene. BERP was then considered as a closest member of the same family of genes. In order to test this hypothesis, total RNA was isolated from E10.5 mouse embryos and a reverse transcription PCR amplification was performed with a pair of degenerated primers designed from the highest conserved regions of both KIAA0517 and BERP genes. If correct, a $1.6 \mathrm{~kb}$ 


\section{Results}

DNA fragment would be amplified containing mixture of both mouse BERP gene and mouse orthologue of KIAA0517.

Degenerated primers for RT PCR amplification of Ei-62 clone:

\section{5' (G/A)GGA(T/C)GTGGTGGA(G/A)CAGCA 3' \\ 5' CCCAGTC(A/G)GCCAC(A/G)ATGATGT 3'}

Indeed, a $1.6 \mathrm{~kb}$ fragment was amplified and subsequent cloning into pGEM-T easy vector and sequencing confirmed amplification of both mouse BERP and mouse orthologue of KIAA0517 genes. Importantly, the $370 \mathrm{bp}$ sequence of Ei-62 RACE PCR product exactly matched with a part of the amplified 1.6 kb PCR fragment. For this reason it was concluded that the Ei-62 RACE PCR product was, indeed, the orthologue of the KIAA0517 EST clone.

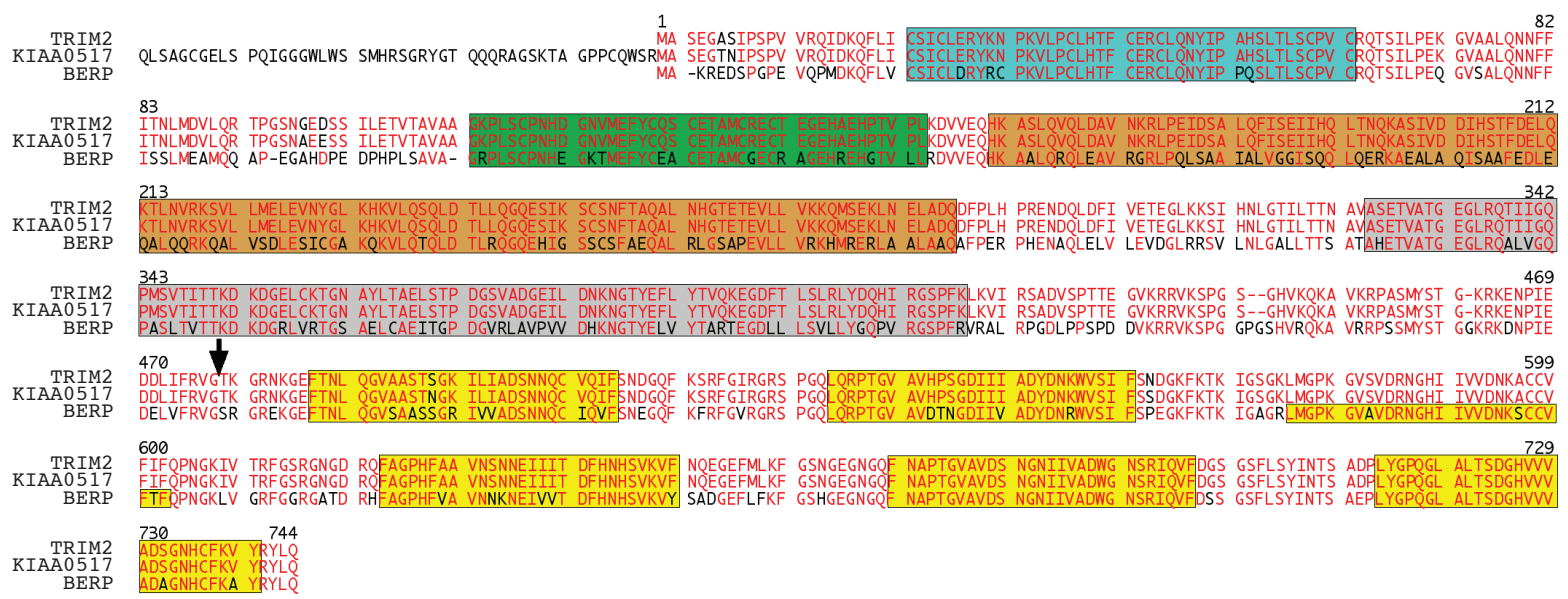

Fig. 9: Comparison of the deduced aminoacide sequence of KIAA0517, TRIM2 and BERP. The functional domains are highlighted: blue - RING finger domain; green - B box; brown - coiled coil; gray - filamin/ABP280 repeat; yellow - NHL repeats. Arrow indicates the deduced gene trap vector insertion site. 


\section{Results}

\subsubsection{Identification of the trapped gene as RING-finger protein TRIM2}

Since the PCR amplified DNA fragment did not contain the full open reading frame of the mouse KIAA0517 orthologue, the mouse embryonic day E15.5 cDNA library (Clontech) was screened with the $1.6 \mathrm{~kb}$ PCR fragment used as a probe. The screening provided 2 overlapping clones covering the whole ORF of mouse KIAA0517 orthologue and a part of its 3' untranslated region.

Recently, another group of researchers cloned the same gene in a PCR-based cDNA subtraction screen for genes expressed in the hippocampus of repeatedly pentylenetetrazol (PTZ)-treated mice (Ohkawa, Kokura et al. 2001) and named it NARF (Neural activityrelated RING finger protein). Since there is already a gene called Narf (the nuclear prelamin A recognition factor) (Barton and Worman 1999) and since NARF belongs, together with BERP, to the tripartite motif family of RING finger proteins (Reymond, Meroni et al. 2001), the gene is also referred to as Trim2. This is the Locus Link name (the official name http:// www.ncbi.nlm.nih.gov/LocusLink/LocRpt.cgi?l=80890), and I have used it in the following chapters. The mouse gene trap line carrying mutation in Trim2 will be referred to as Trim $2^{\text {GT }}$ mouse line.

\subsection{Characterization of Trim2 gene with respect to the GT mutation}

The cDNA of Trim2 has 7177bp, of which 2232 bp represents coding region. Based on the comparison with mouse genomic DNA sequence obtained from Celera Discovery System database (http://www.celera.com/), the cDNA is divided into 12 exons (Fig. 12).

The deduced amino acid sequence (744 aa) contains several functional domains (Figs. 9\&10): at the $\mathrm{N}$ terminus, there is a RBCC RING finger domain (Borden and Freemont 1996) composed of two separate zinc finger domains - RING finger and B box - followed by a Coiled coil domain. The motif is also referred to as TRIM domain (for Tripartite motif) (Reymond, Meroni et al. 2001) and is considered as protein-protein interaction motif. It was discovered in number of proteins involved in ubiquitination, apoptosis and various diseases (Shimura, Hattori et al. 2000; Niwa, Ishigaki et al. 2002; Dho and Kwon 2003). 


\section{Results}

The RING finger domain is followed by a Filamin repeat (Gorlin, Yamin et al. 1990) a protein-protein interaction domain involved in protein dimerization and actin filament crosslinking.

Finally, five NHL repeats believed to mediate protein-protein interactions and superficially resembling WD-40 repeats (Slack and Ruvkun 1998) are located at the C terminus (Fig 10).

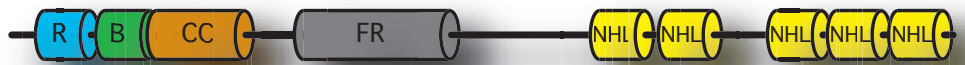

Fig. 10: The functional domains present in the TRIM 2 protein. $\mathrm{R}$ - RING finger; B -

B box; CC - coiled coil; FR - filamin repeat; NHL - repeats

By the means of Fluorescence in situ hybridization (FISH) Trim2 gene was localized in the mouse chromosome 3 region E3 (fig. 11)
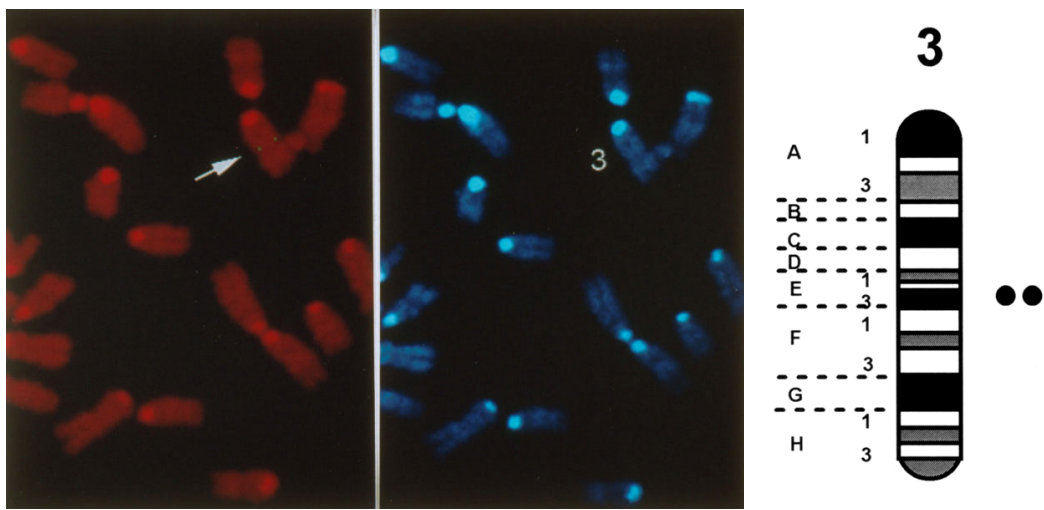

Fig. 11: Chromozomal localization of Trim2 gene analyzed by Fluorescence in situ hybridization (FISH). Left panel shows the FISH signal on mouse chromozome, the middle panel shows the same mitotic figure stained with DAPI to identify chromosome 3 . The right panel shows a diagram of chromosome 3 with the dots representing the area where FISH signal was detected. 


\section{Results}

Integration site of the GT vector inside the Trim2 locus was determined from comparison of Trim2 cDNA sequence to the sequence of 5' RACE PCR product and Trim2 genomic sequence. The GT vector insertion occurred according to the analysis into the 6th intron between exons 6 and 7 (Fig.12).

Trim2 locus

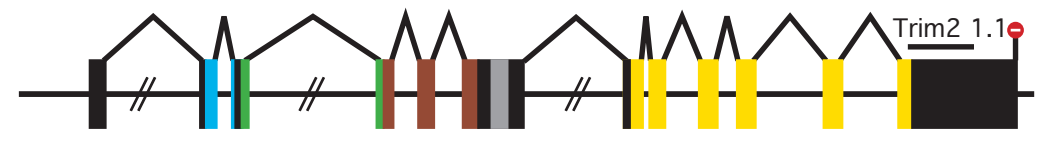

Trim2GT locus
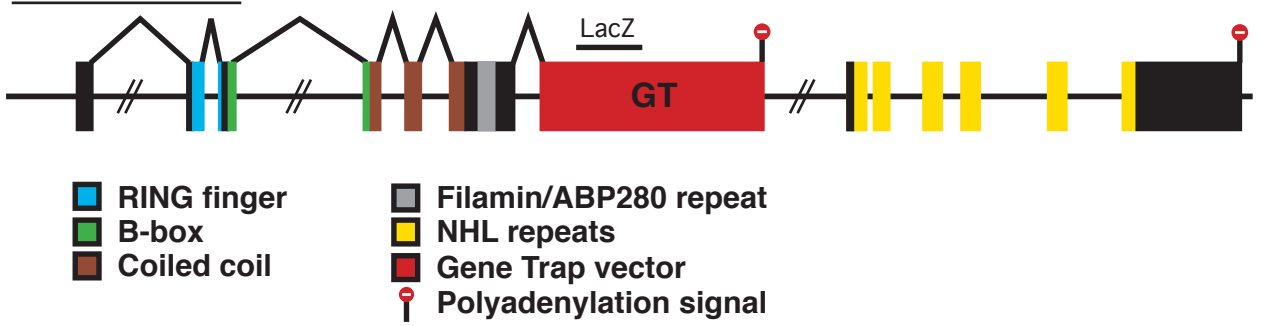

Fig. 12: Structure of the Trim 2 locus. Trim 2 cDNA is divided into 12 exons. Transcription of the Trim2 ${ }^{\mathrm{GT}}$ locus is stopped by polyadenylation signal at the 3 ' end of the gene trap vector integrated into the $6^{\text {th }}$ intron. The position of Trim2 1.1 and LacZ probes used for genotyping of the Trim2 ${ }^{\mathrm{GT}}$ mice by southern blotting as well as for in situ hybridization and northern blotting are indicated

As an additional support for the deduced insertion site, the mutant locus was amplified from genomic DNA of homozygous animals by PCR using primers derived from 3' part of Trim 2 exon 6 (forward primer) and 5' part of the GT vector (reverse primer).

Primers:

Forward: 5' GACGACCTGATCTTCCGAGTC 3' MBA51

Reverse: 5' GGCCGCTTGTCCTCTTTGTT 3'en-2 


\section{Results}

The PCR amplified fragment was sequenced and compared with the mouse genomic sequence in the Celera Discovery System database. All the 3' part of the exon 6, adjacent sequence of the intron 6 and the 5' part of the GT vector were identified in the sequence confirming the GT vector insertion indeed occurred into the 6th intron, 780 bp behind the end of exon 6 (Fig. 13).

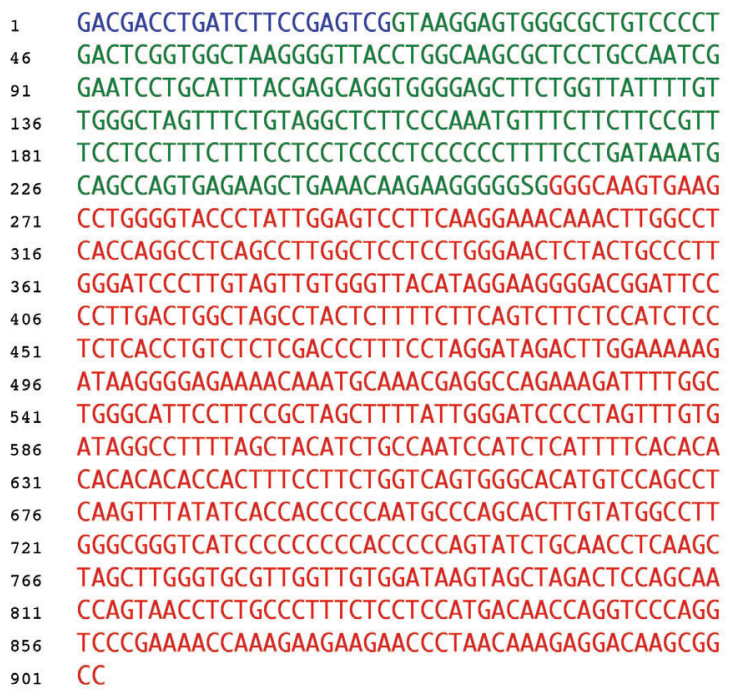

Fig. 13: PCR amplyfication of seqence 5' part from the gene trap vector insertion site. Blue color - 3' part of the Trim2's exon 6; green color - intron no. 6; red color - gene trap vector (5' part)

\subsection{Trim2 Expression Pattern}

Having the sequence of the Ei-62 mutant gene identified and cloned, the expression analysis of the Trim $2^{\mathrm{GT}}$ gene trap line, previously carried out only by means of $\beta$-gal staining, could also be confirmed by radioactive and/or non-radioactive in-situ hybridization with a Trim 2 probe. Co-localization of the expression patterns generated by both methods confirmed not only the correct identification of the GT mutation, but also the proper function of the gene trap vector in all the tissues expressing the "trapped" gene. 


\section{Results}

A more detailed expression pattern analysis was carried out with a focus on the postnatal CNS Trim2 expression, our main area of interest.

\subsubsection{Trim2 expression in the Cerebellum}

In adult cerebellum the strongest $\beta$-gal staining was detected in Purkinje neurons and neurons of the deep cerebellar nuclei (DCN). (Fig. 14) The non-radioactive in situ hybridization, more suitable for detection of the one-cell layer of Purkinje neurons, confirmed Trim2 expression in the Purkinje cells and DCN.

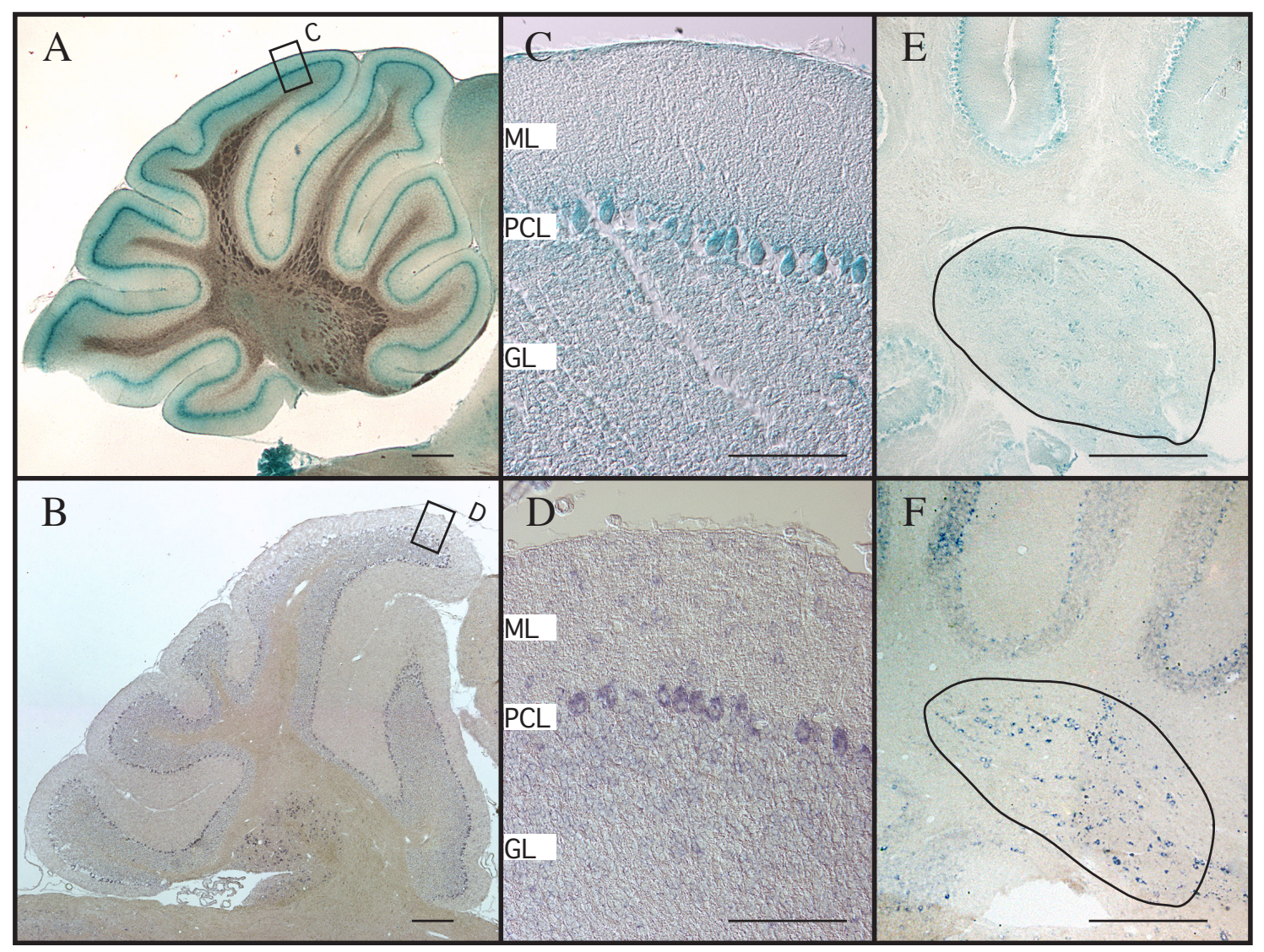

Fig. 14: Expression of Trim2 in the adult cerebellum (A, B) was detected in Purkinje cells $(C, D)$ and in deep cerebellar nuclei (E, F - highlighted area). Both $\beta$-gal staining of the Trim2 ${ }^{\mathrm{GT}}$ heterozygotes $(\mathrm{A}, \mathrm{C}, \mathrm{E})$ and in situ hybridization with Trim2 1.1 probe $(\mathrm{B}, \mathrm{D}, \mathrm{F})$ resulted in the same expression pattern. $\mathrm{ML}$ - molecular layer; PCL Purkinje cell layer; GL - granule layer. Scale bars: A,B - $200 \mu \mathrm{m}$; C, D, E, F - 100 $\mu \mathrm{m}$. 


\section{Results}

\subsubsection{Trim2 expression in the Retina}

Expression of Trim2 was detected in two retinal layers (Fig. 15): ganglionic cell layer (GCL) and inner nuclear layer (INL). By the means of $\beta$-gal staining signal was detected even in the outer plexiform layer (OPL) where dendrites of bipolar cells make contacts with axons of the photoreceptors. No signal was detected in the outer nuclear layer (ONL) by any of the aforementioned techniques.

\subsubsection{Trim2 expression in the Hippocampus}

The strongest expression of Trim2 in the adult brain was found in hippocampus. Both $\beta$-gal staining as well as radioactive and non-radioactive in situ hybridization detected strong signal in pyriamidal cells of CA1, CA2 as well as CA3 hippocampal regions and granule cells of dentate gyrus (DG). (fig. 15). $\beta$-gal staining detected in stratum radiatum (Rad) of hippocampus and molecular layer (Mol) of dentate gyrus corresponds to the dendrites of CA1, CA2, CA3 and DG neurons respectively. The signal is not detected by the in situ hybridization since the mRNA concentration detected by the method is always highest around the nuclear area. 


\section{Results}

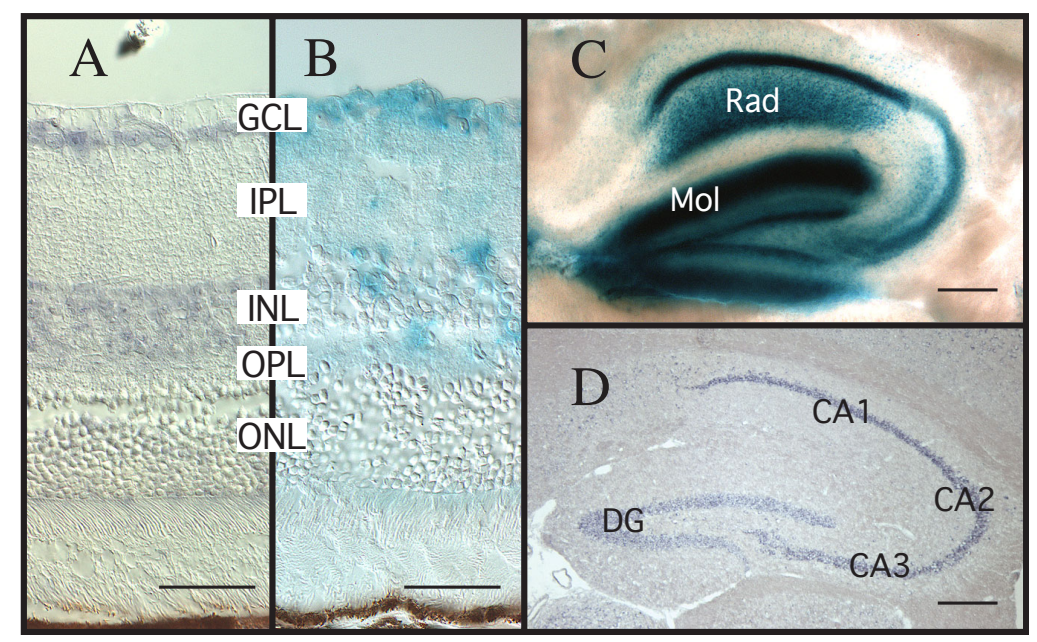

Fig. 15: Trim2 expression was detected in the adult retinal ganglionic cell layer and inner nuclear layer (A, B) by both $\beta$-gal staining (A) and nonradioactive in situ hybridization (B). Sagittal sections of the adult hippocampus (C, D) show Trim2 expression in both granule cells of dentate gyrus (DG) as well as pyriamidal cells of hippocampal CA1, CA2 and CA3 regions. $\beta$-gal signal detected in hippocampal stratum radiatum (Rad) and molecular layer (Mol) of dentate gyrus is related to the dendrites of pyramidal and granule neurons. A, D - in situ hybridization; B, C - $\beta$-gal staining. GCL - ganglionic cell layer; IPL - inner plexiform layer; ONL - outer nuclear layer; INL - inner nuclear layer; OPL - outer plexiform layer. Scale bars: A, B - $30 \mu \mathrm{m} ; \mathrm{C}, \mathrm{D}-100 \mu \mathrm{m}$.

\subsection{Phenotype of Trim2 ${ }^{\mathrm{GT}}$ mutant mice}

The Trim $2^{\mathrm{GT}}$ mutation, originally kept in the NMRI mouse outbred strain, was subsequently backcrossed to the C57/B16 inbred background in order to eliminate any unrelated mutations originating from electroporation of the ES cells as well as to reduce variability of a possible phenotype in the genetically defined inbred background.

After 7 generations of backcrossing to the C57/B16 background homozygous mice were generated from crossing heterozygous littermates and phenotype of the homozygotes was analyzed. 


\section{Results}

\subsubsection{Genotyping and the primary molecular analysis of the Trim2 ${ }^{\mathrm{GT}}$ mutants}

The identification of chromosomal localization of Trim2 in mouse was useful for designing a PCR based genotyping strategy of Trim2 ${ }^{\mathrm{GT}}$ mice. Since the GT construct was electroporated into the ES cells originating from the mouse strain 129SV but the mouse line created was backcrossed into the C57/B16 background, the majority of its genome was of the C57/B16 origin. The mutant locus, though, originated from 129SV ES cells. For the reason a pair of PCR primers producing a length polymorphism between mouse strains 129SV and C57/B16 and coming from the immediate vicinity of the mutant locus could be used for genotyping of the mouse mutants.

Simple sequence length polymorphism markers (SSLP) obtained from the Whitehead Institute homepage (http://www-genome.wi.mit.edu/) and localized within $0.1 \mathrm{cM}$ distance from the Trim 2 locus in the mouse chromosome 3 region E3, were tested for PCR polymorphism between mouse strains C57/B16 and 129SV.

The SSLP pair D3Mit97L and D3Mit97R was shown to produce ca 6 nucleotides polymorphism between the two mouse strains (C57/B16 - 107 bp; 129SV ca 101 bp). The specificity of the genotyping was further confirmed by comparing the results to Southern blotting based genotyping and since the match was $100 \%(n=124)$ the markers were used for genotyping of the mutant mice.

The gene trap vector integration disrupts wild type transcript by introducing a novel polyadenylation signal at the end of the gene trap vector coding sequence. This leads in the mutant locus to generation of a fusion transcript $(7.0 \mathrm{~kb})$ containing the 5 ' part of the trapped gene mRNA (1719 bp) fused to the RNA transcript of the gene trap vector $(5.3 \mathrm{~kb})$. We analyzed the total RNA isolated from adult brains of wild type, heterozygous and homozygous mice to assess whether GT vector insertion leads to a full knock-out phenotype in the homozygous mice or whether, due to an alternative splicing, a certain amount of the full-length wild type transcript (ca $7.2 \mathrm{~kb}$ ) is still being generated. Northern blotting (quantified by instant imager, Packard inc.) revealed presence of approximately $5 \%$ of the 


\section{Results}

wild type transcript in the homozygous mutant mice (Fig. 16) suggesting the GT mutation results in a hypomorphic phenotype.

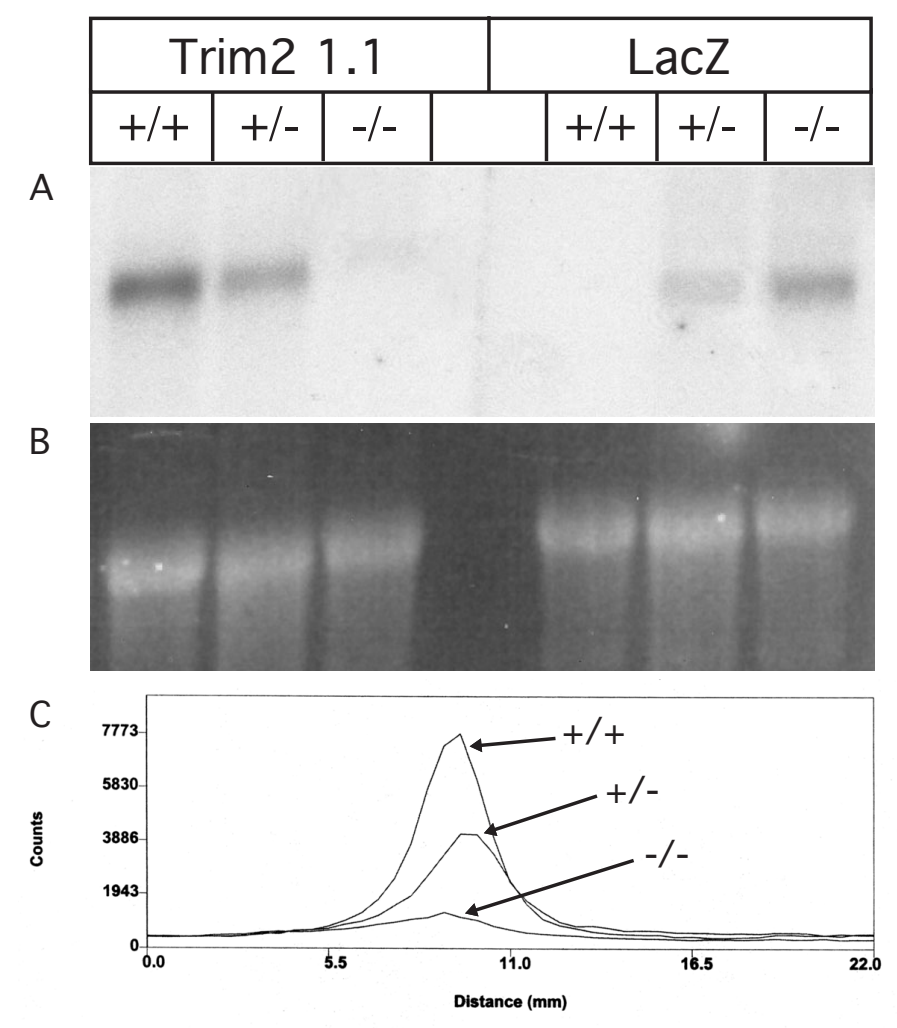

Fig. 16: Analysis of Trim 2 and gene trap vector transcripts in total RNA isolated from brains of WT, heterozygous and homozygous mice. Northern blotting with Trim2 1.1 probe $(\mathrm{A})$, quantified by instant imager $(\mathrm{C})$ revealed decrease of the WT Trim2 transcript in heterozygous Trim $2^{\mathrm{GT}}$ mutants to $55 \%$ of the WT value and to $7 \%$ of the WT value in homozygotes. Transcription of the gene trap vector was analyzed by hybridization with LacZ probe showing ca. 50\% increase of the signal in the homozygotes when compared to the Trim $2^{\mathrm{GT}}$ heterozygotes (A - LacZ). (B - ethidium bromide stained gel as a loading control)

\subsubsection{Trim $2^{\mathrm{GT}}$ mutation causes ataxia and tremor in mice}

The Trim $2^{\text {GT }}$ homozygotes were generated after 7 generations of backcrossing to the C57/B16 background and the phenotype of the mutants was analyzed both behaviorally and 


\section{Results}

histologically. The behavior of the Trim2 homozygotes was indistinguishable from their wild type and heterozygous littermates until approximately one and half months of age. At this age the Trim2 ${ }^{\mathrm{GT}}$ homozygotes started to show an intention tremor followed by gait ataxia (Fig. 17). In the later stages (around 3 months of age) mutant mice suffer additionally from episodes of spontaneous epileptic seizures.

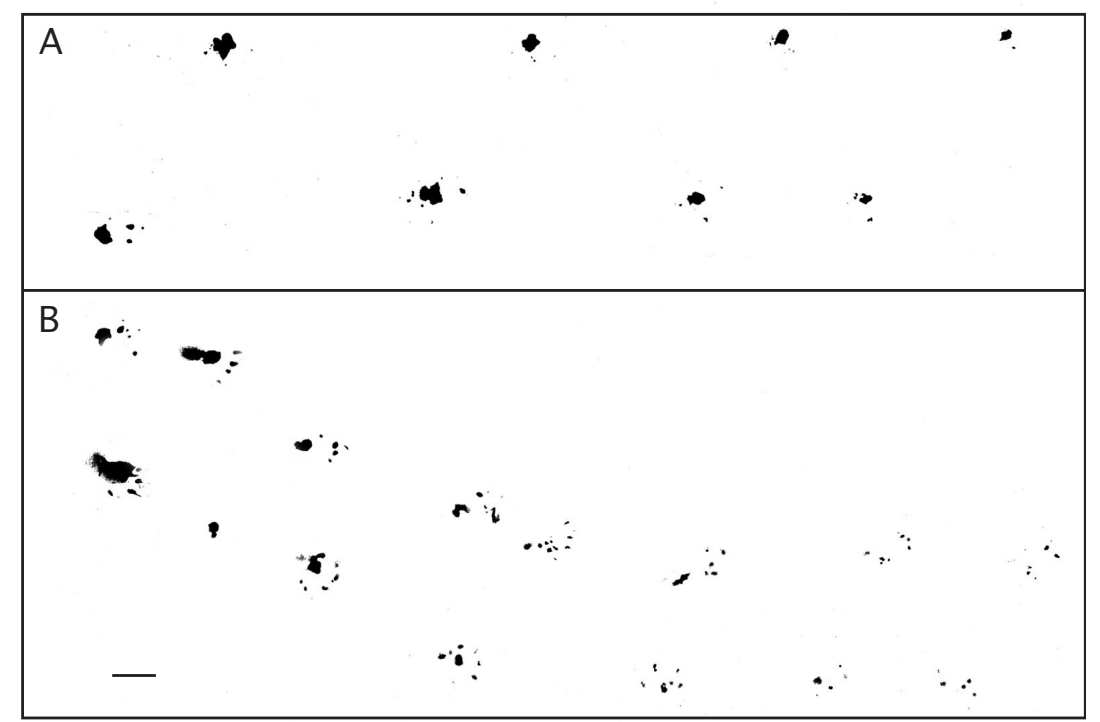

Fig. 17: As demonstrated by hind footprint pattern, 4 month old mutant mice (B) are not able to walk along a straight line. When compared to the wild type littermates (A) their steps are significantly smaller and they walk with a wide base rolling motion from side to side often ending with large amplitude tremor of the whole body. Scale bar $1 \mathrm{~cm}$

Many human hereditary syndromes are caused by chromosome translocations or deletions usually affecting function of a whole group of genes. Chromosomal localization of the aberrant locus in human and molecular dissection of its mouse homologue is the first step to uncover the genes and molecular cascades underlying the disease.

Trim2 is localized in mouse chromosome 3 area E3 which corresponds to human locus 4q32 as derived from the Human-mouse homology map (http:// www.ncbi.nlm.nih.gov/Homology/). Analysis of the genes and disease database at (http:// 


\section{Results}

www.ncbi.nlm.nih.gov/) revealed that up to now no human syndrome has been mapped within 4q32 chromosomal locus.

\subsubsection{Histological analysis of Trim2 $2^{\mathrm{GT}}$ mutants}

In order to understand the origins of the observed behavioral defects, homozygous mice were analyzed histologically at different stages before and after the onset of the phenotype.

\subsubsection{Cerebellum}

Tremor and ataxia, well pronounced in the Trim $2^{\mathrm{GT}}$ mutants, are strongly suggestive of a cerebellar malfunction (Diener and Dichgans 1992). Since expression of Trim2 was detected in cerebellar Purkinje cells and deep cerebellar nuclei, Trim2 ${ }^{\mathrm{GT}}$ mutant cerebella were systematically analyzed for presence of any histological and/or anatomical defect.

\section{a) Purkinje cells}

Cerebellar Purkinje cells were visualized by immuno-staining with anti-calbindin antibodies specifically staining Purkinje neurons. Analysis of cerebella of the 5 months old Trim2 ${ }^{\mathrm{GT}}$ homozygotes revealed a substantial loss of Purkinje cells particularly in the anterior and posterior lobes of vermis (Figs.18, 19). Reduced number of the PCs was also detected in the cerebellar flocculi. The central and inferior lobes and the cerebellar hemispheres were always the least affected.

To answer the question whether lack of Purkinje neurons is due to a defect in their development or due to degeneration, Trim $2^{\mathrm{GT}}$ mutants were analyzed in several different postnatal stages before and after the onset of tremor and ataxias.

Cerebella of the one-month old homozygotes didn't show any difference in number or morphology of PCs to their WT or heterozygous littermates (Fig.18) indicating degeneration is responsible for reduced number of PCs. First patches lacking Purkinje cells were seen in the Purkinje cell layer at around P50. At P62 most of the PCs were not present in PC 


\section{Results}

layer any more. For the reason it was concluded that most of the PCs degenerate between the postnatal days P50 and P62.

Detection of degenerating PCs raised a question whether the cell death follows apoptotic or rather necrotic pathway. No nuclear fragmentation (a hallmark of apoptosis) was visualized via TUNEL assay in the PC layer of the Trim2 ${ }^{\mathrm{GT}}$ homozygous mice at P50 or P60 (data not shown) suggesting the death of the PCs is rather necrotic then apoptotic.

Number of basket/stellate interneurons was not changed in the 5 months old homozygotes when compared to their littermates by immunostainig with anti-parvalbumin antibodies (fig. 19).

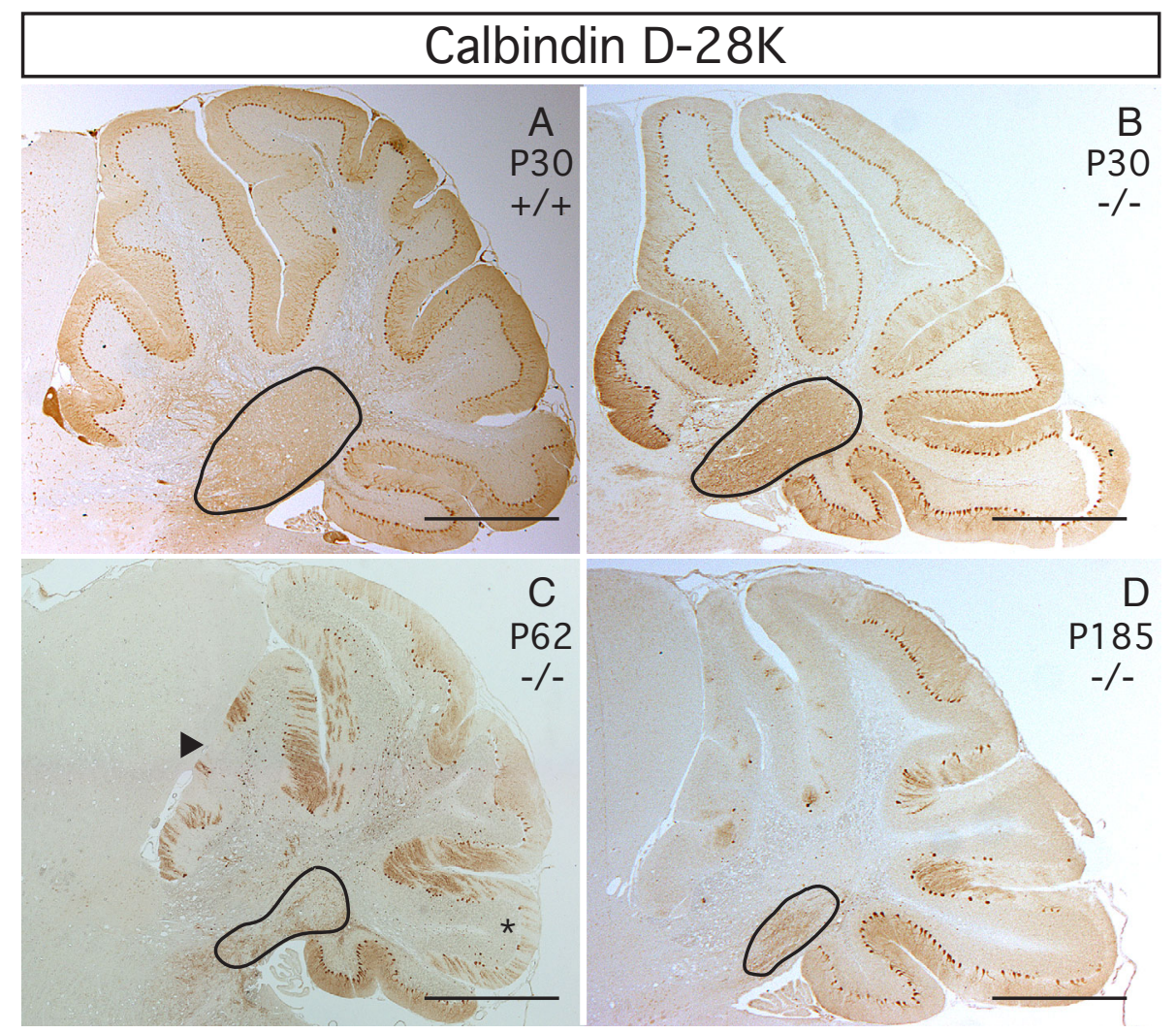

Fig. 18: Degeneration of Purkinje neurons, as visualized by immunohistochemical staining with anti-calbindin D-28K antibodies, starts around postnatal day 40. At postnatal day $30(\mathrm{~A}, \mathrm{~B})$ no difference in number of Purkinje neurons between WT (A) and homozygous (B) animals was detected. At P62 (C) a severe loss of Purkinje neurons is visible particularly in anterior (arrowhead) and posterior (asterisk) cerebellar lobes. In the 6 months old mutants majority of PCs is already degenerated (D). Together with PC degeneration, degeneration of deep cerebellar nuclei was detected with anti-calbindin D-28K antibodies as highlighted on the sections. Scale bars: $700 \mu \mathrm{m}$. 


\section{Results}

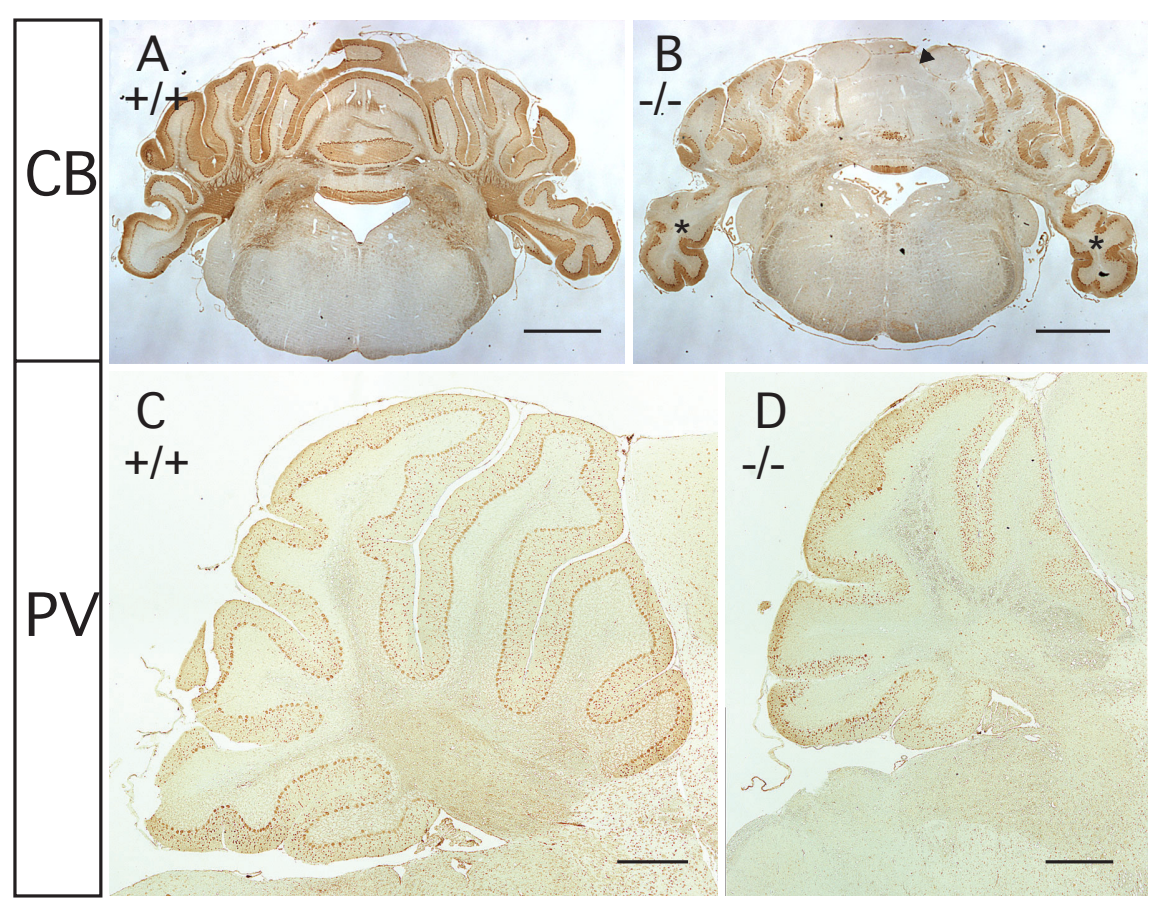

Fig. 19: Vermis (arrowhead) is the most affected cerebellar area as seen on coronal section of the mutant cerebellum stained with anti-calbindin D-28K (CB) antibodies (B). Degeneration was detected also in cerebellar flocculi (asterisk). Cerebellar hemispheres are the least affected area. (A - cerebellum of a WT littermate). No significant reduction of number of stellate interneurons was seen in 5 months old mutant cerebella (D) immunostained with anti-parvalbumin (PB) antibodies when compared to their WT littermates (C). Scale bars $500 \mu \mathrm{m}$.

\section{$\underline{\text { Axonal swelling of Purkinje cells }}$}

To understand the basis of cerebellar degeneration in Trim2 ${ }^{\mathrm{GT}}$ mice Fluoro-Jade $\mathrm{b}$ staining of adult cerebellar sections was carried out. Fluoro-Jade B (FJ), is an anionic fluorescein derivative useful for the histological staining of neurons undergoing degeneration. Its spectrum is supposedly broader then TUNEL assay that detects only apoptotic neurons since even neurons undergoing necrotic death were shown to be Fluoro-Jade B positive.

The staining of Trim $2^{\mathrm{GT}}$ cerebella didn't reveal any positive signal in molecular and Purkinje cell layers. FJ fluorescence was, thought, detected in the cerebellar white matter (Fig. 20) where efferent axons of the PCs are located. 


\section{Results}

In order to analyze structure of the Trim $2^{\mathrm{GT}}$ Purkinje cell axons, fluorescent immunostaining with anti-calbindinD-28K was performed. Presence of enormous swellings was detected in many axons of the remaining Purkinje cells in the 4 months old Trim2 ${ }^{\text {GT }}$ homozygotes (Fig. 21). Besides, axonal swellings were detected in the cerebellar white matter, where Fluoro-Jade B fluorescence was observed suggesting the FJ signal in the white matter was confined to the degenerating Purkinje cell axons (Fig.22).

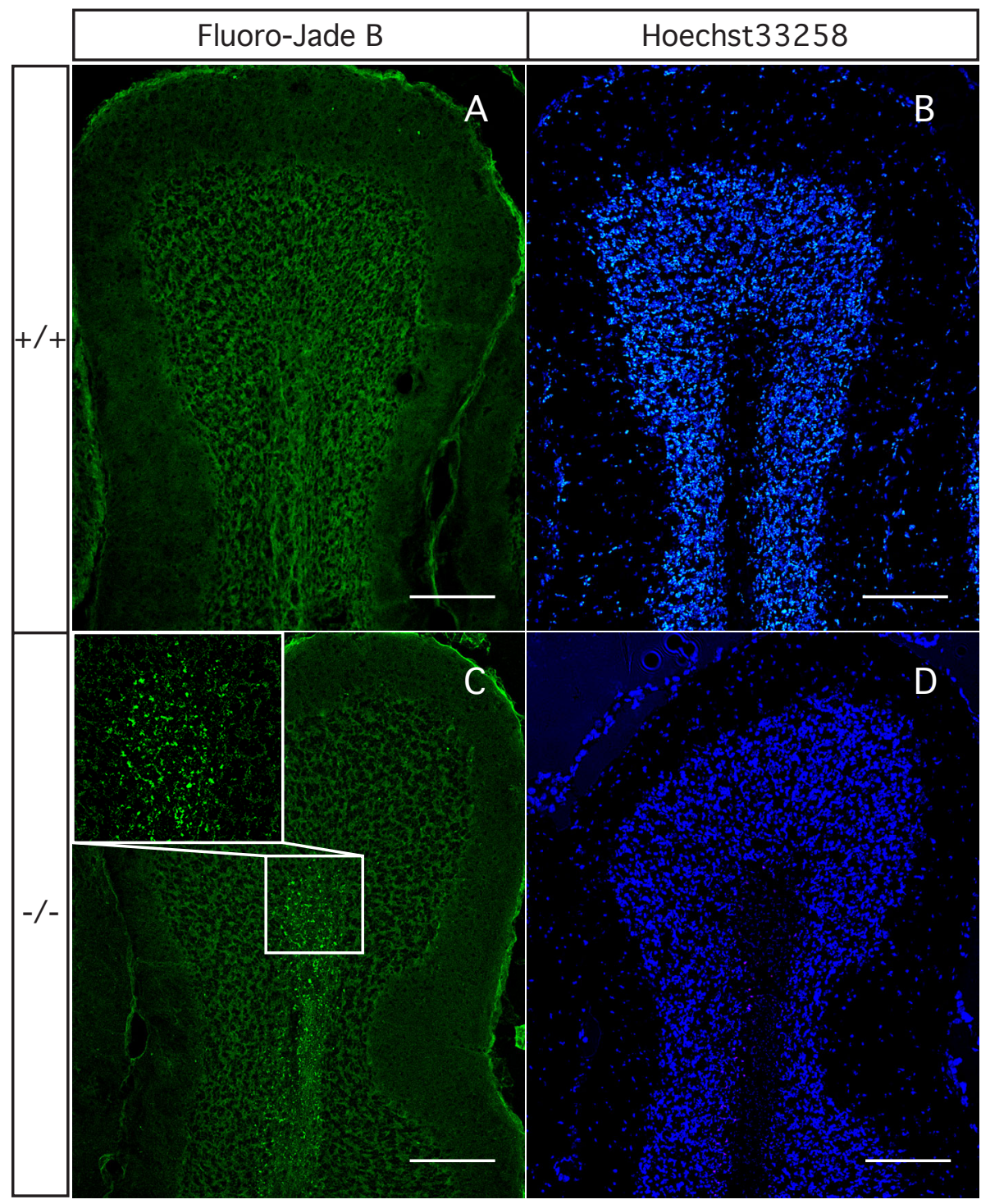

Fig. 20: Increased Fluoro-Jade B fluorescence was found in the cerebellar white matter of the 4 months old Trim2 ${ }^{\mathrm{GT}}$ homozygotes (C, D). No signal was detected in their WT littermates (A, B). (B, D - Hoechst33258 nuclear counterstaining). Scale bars - $100 \mu \mathrm{m}$. 


\section{Results}

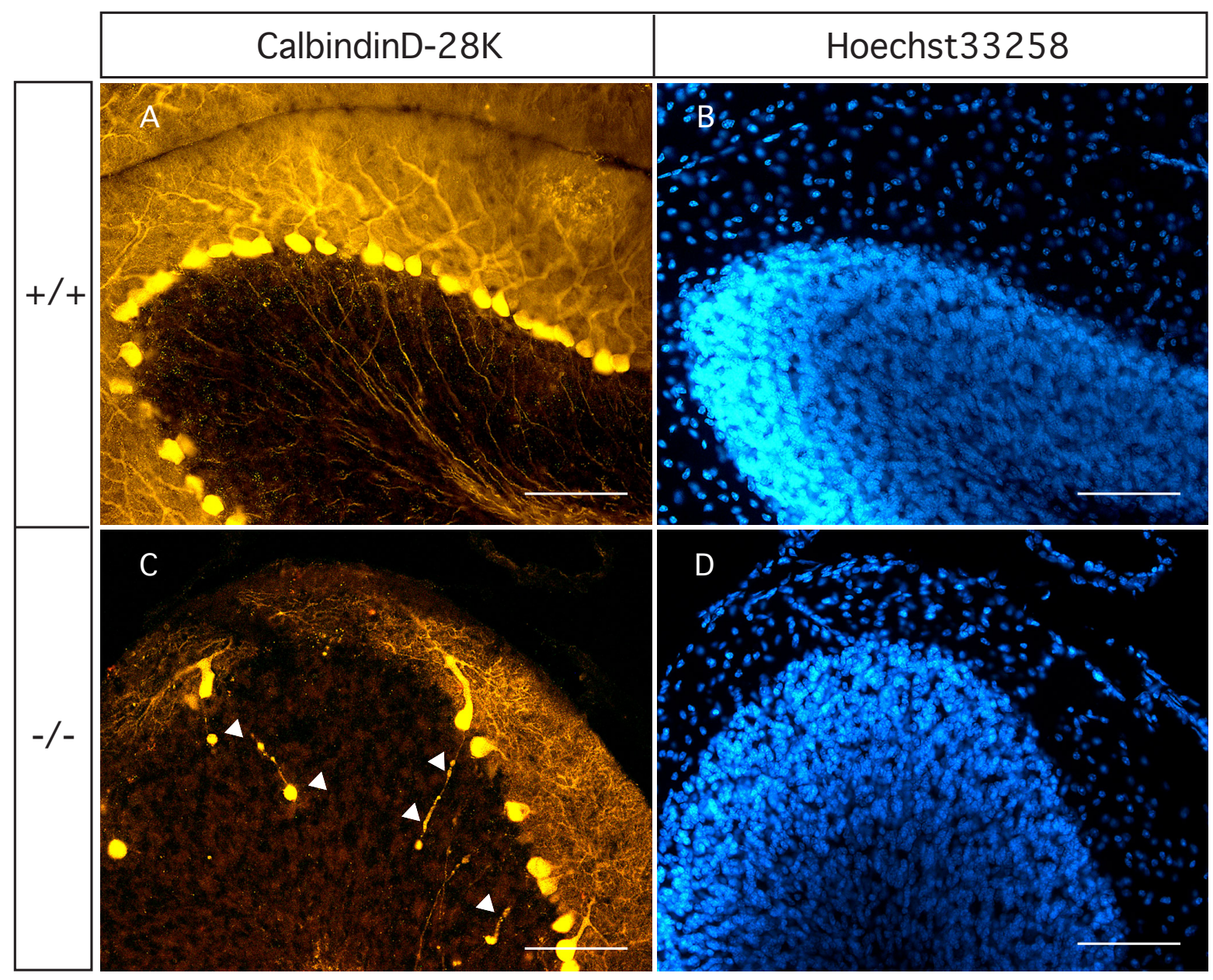

Fig. 21: Axonal swellings are present in the Trim $2^{\mathrm{GT}}$ mutant Purkinje cell axons (C arrowheads) as visualized by fluorescent anti-calbindin immunostaining. No axonal swellings were seen in the WT littermates (A). B, D - Hoechst33258 nuclear counterstaining. Scale bars $-100 \mu \mathrm{m}$. 


\section{Results}

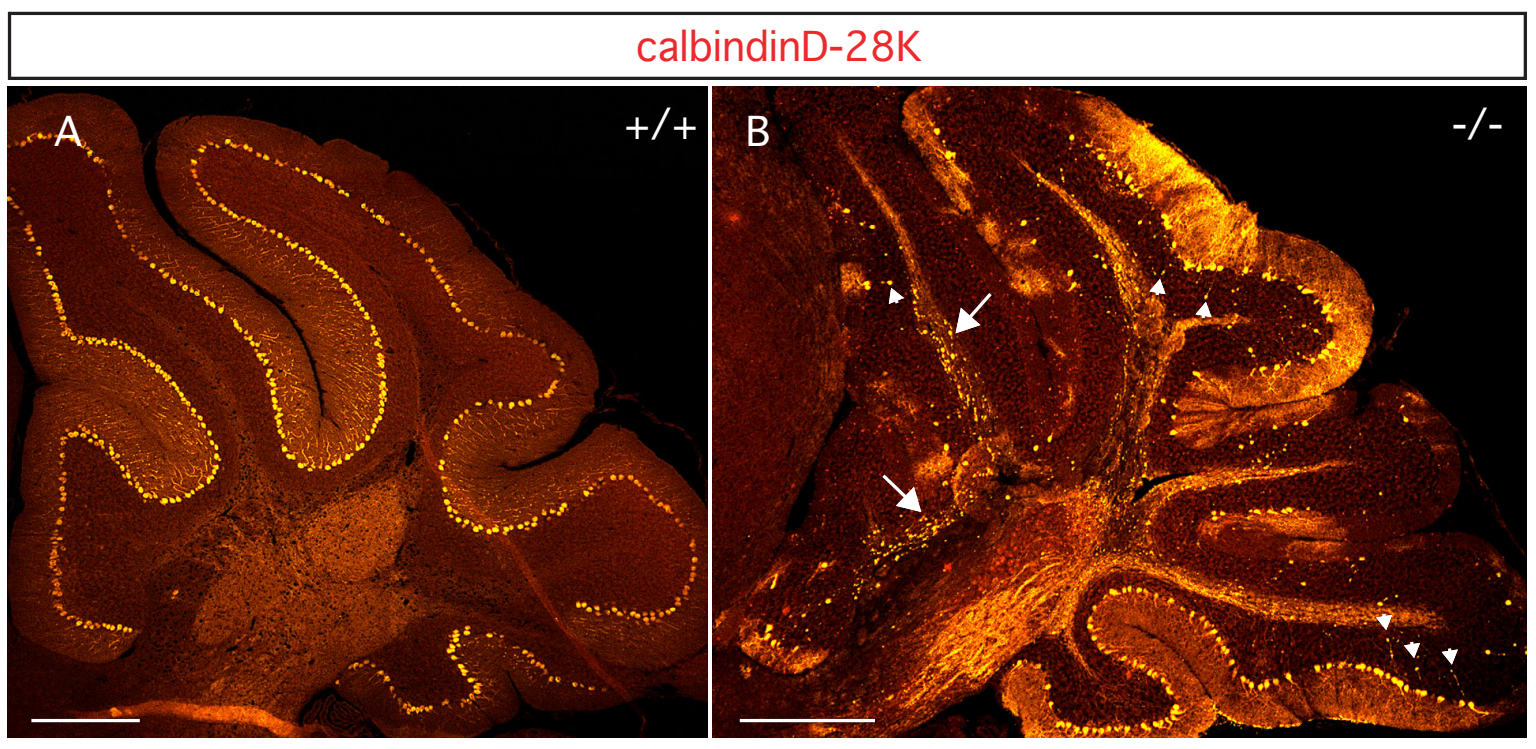

Fig. 22: Purkinje cell axonal swellings are present both in the granule layer (B, arrowheads) as well as in the cerebellar white matter (B, arrows) of the 4 months old Trim2 ${ }^{\mathrm{GT}}$ mutant mice. No axonal sewllings were detected in WT cerebella (A). Scale bars $700 \mu \mathrm{m}$. 


\section{Results}

\section{b) Deep cerebellar nuclei (DCN)}

The DCN neurons are the main target of the inhibitory projections of Purkinje cells. Besides, both $\beta$-gal expression as well as Trim2 RNA transcripts were detected in DCN raising a question about their fate in the Trim2 ${ }^{\mathrm{GT}}$ mutants.

The anti-calbindin immunostaining specific for the DCN neurons revealed a size reduction of the DCN of already 2 months old Trim $2^{\mathrm{GT}}$ homozygotes (Fig. 18). No significant size difference was seen in 1 month old homozytes suggesting degeneration is responsible for DCN size reduction.

\section{c) Climbing fibers (CF)}

Climbing fibers, the excitatory projections of the inferior olive (IO), make direct connections with Purkinje cells. Degeneration of Purkinje cells is thus likely to affect CFs, similarly as in the case of DCN. Besides, establishment of the proper CF-PC connections in the correct one to one manner is know to be crucial for proper cerebellar function as demonstrated by number of cerebellar mutants with multiple climbing fiber innervations (Kano, Hashimoto et al. 1997; Kano, Hashimoto et al. 1998).

Since failure to establish the correct CF-PC connections could in principle lead to the degeneration of PCs, CFs were analyzed in the Trim2 ${ }^{\mathrm{GT}}$ mutants by double immunohistochemistry with anti-VGluT2 (CF and IO marker) and anti-calbindin (PC marker) antibodies.

The staining revealed presence of the correct CF-PC synapses in the adult P30 Trim2 ${ }^{\mathrm{GT}}$ homozygotes as well as in all the remaining PCs of the older (4 months old) mutants. (Fig. 23) In contrast, no CFs were detected in the areas where PCs were not present any more, suggesting that PC degeneration inevitably leads to retraction of CF.

Since the CF come from a brainstem nucleus called Inferior Olive, we extended our histological observations to this nucleus, but were unable to find any anomaly (not shown). This is very likely due to the postnatal and progressive nature of the $\mathrm{CF}$ degeneration, since 


\section{Results}

the sudden and catastrophic destruction of axons at an early embryonic age would probably cause at least some degeneration in the afferent nucleus.

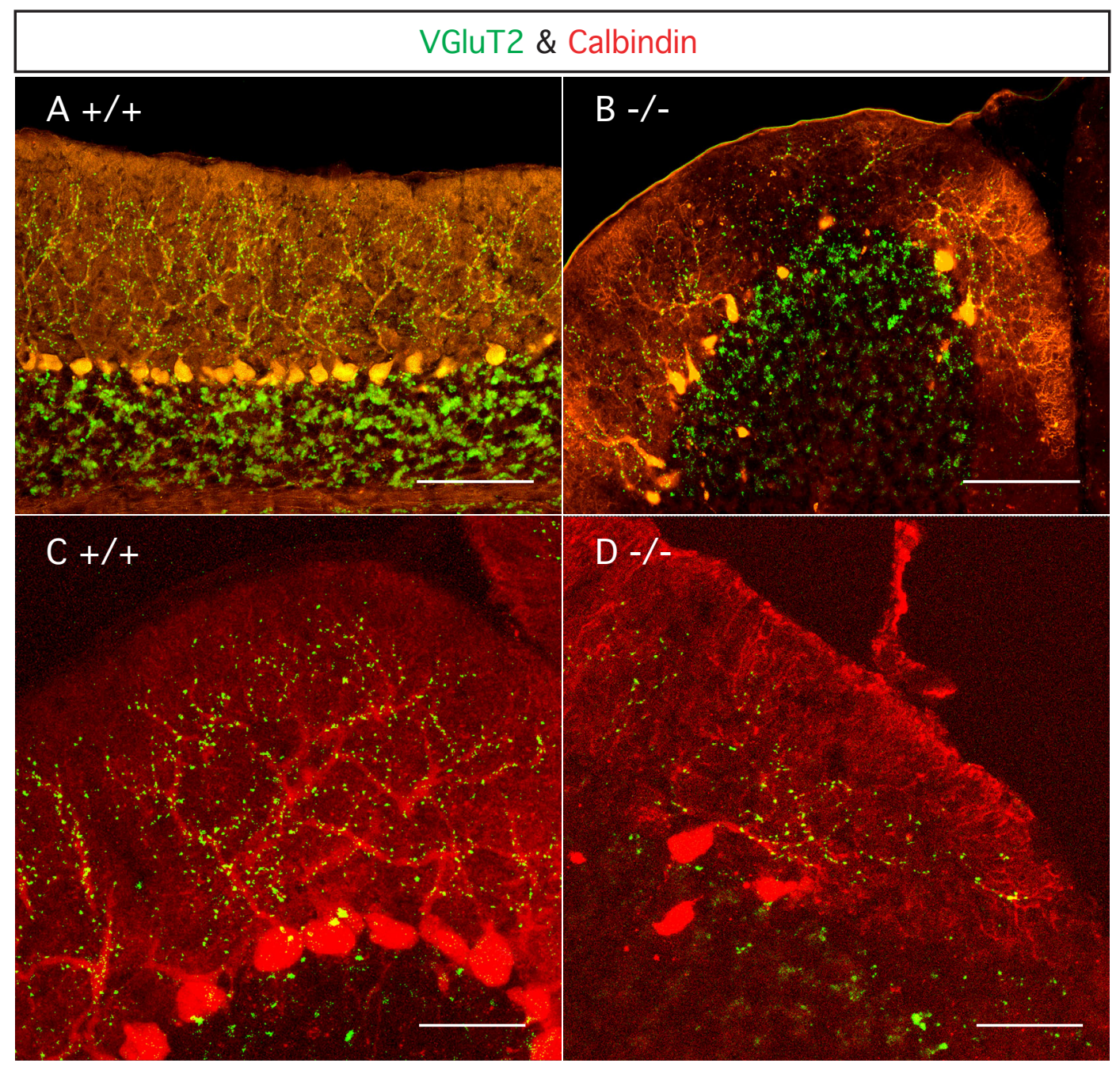

Fig. 23: Innervation of Purkinje cells by climbing fibers was analyzed by Calbindin D-28K, VGluT2 double immunostaining. Climbing fibers (green color, anti-VGluT2) colocalized with Purkinje cell dendrites (red color, anti-calbindin D-28K) in both WT animals (A, C) and homozygotes (B, D) indicating CF-PC synapses were established in Trim2 ${ }^{\mathrm{GT}}$ mutants. No CFs were detected in areas lacking $\mathrm{PCs}$ and no Purkinje cell was seen without $\mathrm{CF}$ innervation. Sections were analyzed by fluorescence (A, B) and confocal (C, D) microscopy. Scale bars: A, B - $100 \mu \mathrm{m}$; C, D - $40 \mu \mathrm{m}$. 


\section{Results}

\subsubsection{Retina}

In several natural mouse cerebellar mutants as Purkinje Cell Degeneration (PCD) or Nervous progressive degeneration of Purkinje cells is accompanied by retinal degeneration (Mullen, Eicher et al. 1976; LaVail, Blanks et al. 1982). Because Trim2 expression was detected in retina, as shown before, retina of Trim $2^{\mathrm{GT}}$ mutants was analyzed in order to see whether Trim $2^{\mathrm{GT}}$ mutation affects also retinal neurons.

Similar to the cerebellar phenotype, in 1 month old homozygotes no difference in the size of the retinal layers or number of the ganglionic cells was detected with Nissl staining (fig. 24). Analysis of the 4 months old homozygous mice and their WT littermates, however, revealed decreased size of particularly outer plexiform layer (OPL), where axons of photoreceptors make connections with dendrites of inner nuclear layer bipolar cells (fig.). Moreover, the average number of ganglionic cells per $100 \mathrm{~mm}$ of the ganglionic cell layer was reduced by one third from 16.4 to 10.8 in 4 months old homozygotes (fig. 24E) suggesting degeneration occurs in both GCL and INL where expression of Trim2 was found. No significant decrease of the photoreceptor layer size was detected. 


\section{Results}

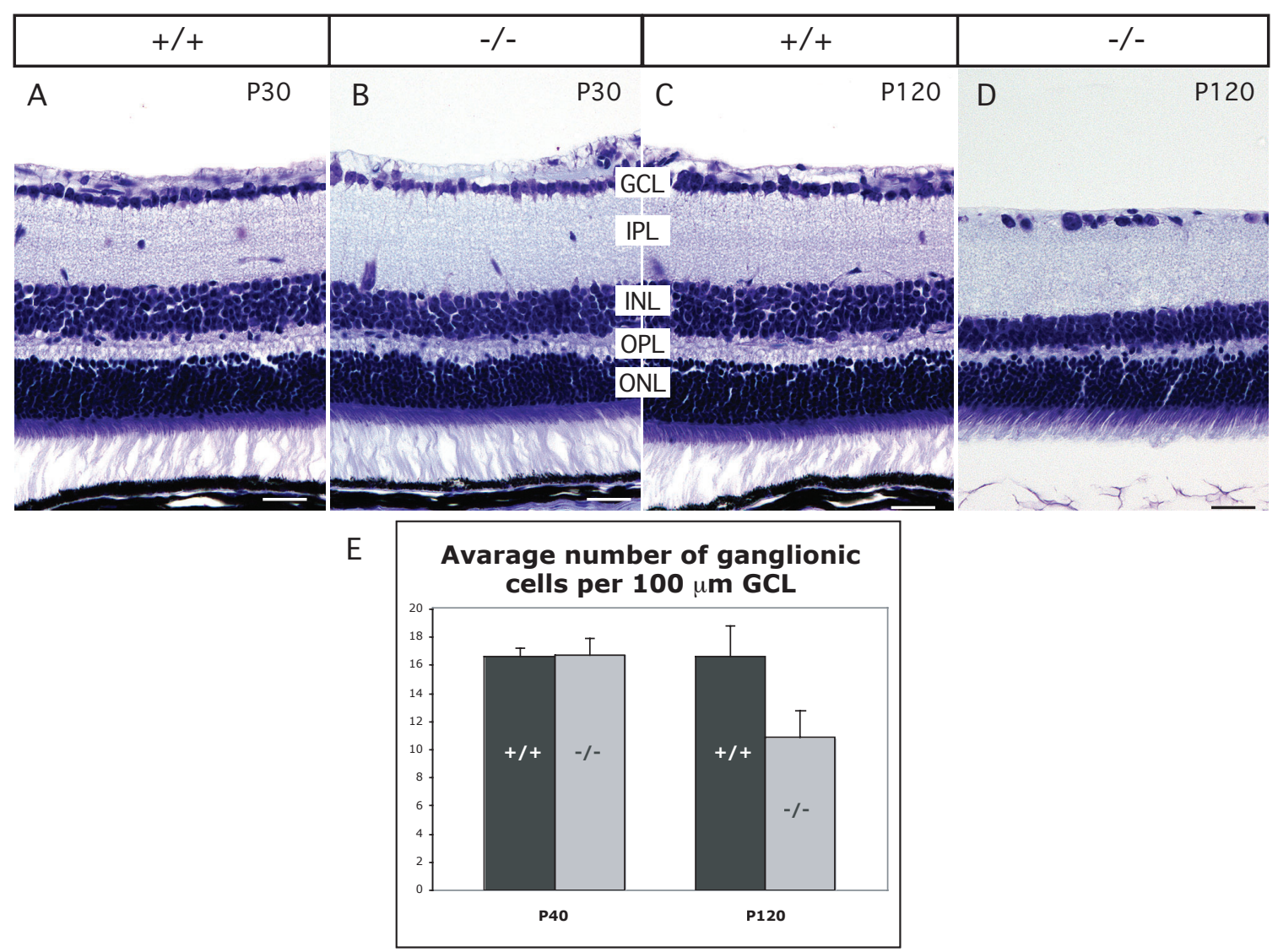

Fig. 24: Retinal degeneration visualized by Niessl staining. No significant difference in size of retinal layers was detected between 1 month old WT (A) and Trim2 ${ }^{\mathrm{GT}}$ homozygous mice (B). Decreased number of ganglionic cells and decreased number of inner nuclear layer (INL) and outer plexiform layer (OPL) was detected in the 4 months old homozygotes (D) when compared to their WT littermates (C). Counting of the number of ganglionic cells per $100 \mu \mathrm{m}$ of the ganglionic cell layer (E) revealed that in avarage, 1/3 of the ganglionic cells is lost in the 4 months old homozygotes $(n=3)$. GCL - ganglionic cell layer; IPL - inner plexiform layer; ONL - outer nuclear layer. Scale bars $30 \mu \mathrm{m}$.

\subsubsection{Hippocampus}

The strongest expression of Trim 2 in the adult brain was detected in hippocampus. This is in agreement with the reported expression of Trim 2 in the hippocampus of repeatedly pentyrenetetrazol-treated (PTZ) or kainate-treated mice (Ohkawa, Kokura et al. 2001).

Both PTZ (blocker of the chloride ionophores coupled to GABAA receptor) and kainate (glutamate receptors agonist) are known to induce expression of the same set of genes as 


\section{Results}

do neurons during long term potentiation (LTP): c-fos, BDNF, etc. (Pozas, Ballabriga et al. 1997; Morimoto, Sato et al. 1998). For the reason kainate and PTZ kindling are used as a model systems of the late phase LTP and supposedly long term memory - i.e. processes dependent on de novo protein synthesis (Lynch, Sayin et al. 2000; Ruthrich, Grecksch et al. 2001). Besides, both of the drugs can provoke seizures in rats and mice when applied at the convulsant doses (Holland, McKeon et al. 1992; Lynch, Sayin et al. 2000).

In their study (Ohkawa, Kokura et al. 2001) show that PTZ and kainate kindling upregulates Trim2 expression in hippocampus and cerebellar Purkinje cells.

Since adult homozygous Trim $2^{\mathrm{GT}}$ mice suffer from episodes of spontaneous seizures, often linked to hippocampal damage, number of hippocampal neurons and overall hippocampal anatomy was examined in mutant animals at different postnatal stages by Nissl staining.

No significant reduction of number of the CA1, CA2, CA3 or Dentate Gyrus neurons, though, was detected by Nissl staining and correspondingly no increased apoptosis (tested by TUNEL assay) was detected on hippocampal sections (not shown) suggesting that a functional defect (as opposed to degeneration) is responsible for the seizures observed in the Trim $2^{\mathrm{GT}}$ mutants.

\subsubsection{Dopaminergic neurons of Substantia Nigra}

Tremor is a well-described symptom accompanying the degeneration of dopaminergic neurons in the Substantia Nigra linked to the Parkinson's disease (Olanow and Tatton 1999). Since tremor was also one of the first behavioral signs observed in the Trim $2^{\mathrm{GT}}$ homozygotes, presence of the dopaminergic neurons in the mutant animals was tested by immunohistochemical staining with anti tyrosine hydroxilase $(\mathrm{TH})$ antibodies (a specific marker for dopaminergic neurons).

The immunostaining didn't reveal any significant difference in the number of dopaminergic neurons between WT and homozygous Trim $2^{\mathrm{GT}}$ littermates suggesting the origin of 


\section{Results}

the tremor seen in Trim2 ${ }^{\mathrm{GT}}$ mutant mice was not the same as in Parkinson's disease (Fig. 25).

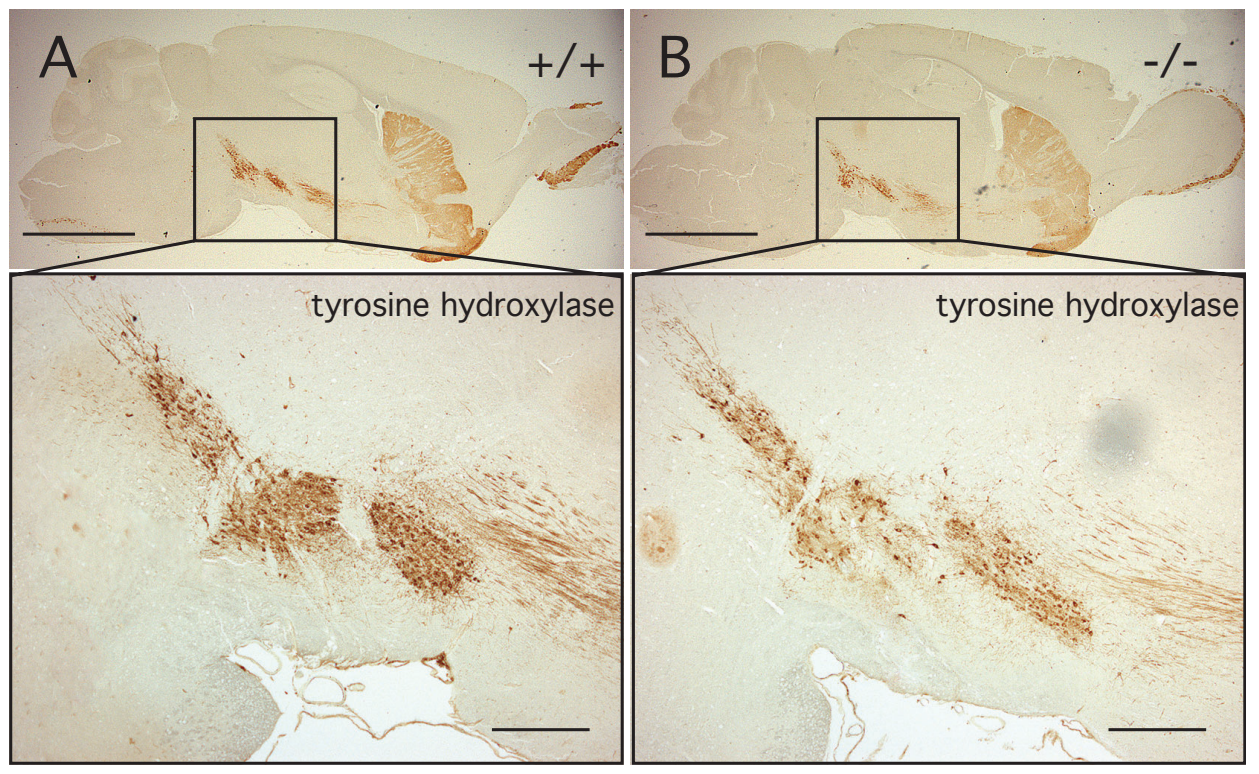

Fig. 25: Number of dopaminergic neurons is not decreased in substantia nigra of Trim2 $2^{\text {GT }}$ mutants as demonstrated by immunohistochemistry with anti-tyrosine hydroxylase antibodies. Scale bars: A, B - 1mm; blowups - $150 \mu \mathrm{m}$.

\subsection{Molecular Analysis of the Trim2 ${ }^{\mathrm{GT}}$ Phenotype}

The TRIM2 protein belongs to the TRIM (tripartite motif) family of RING finger proteins that currently contains 37 members (Reymond, Meroni et al. 2001). Up to now no common cellular function has been assigned to the TRIM proteins but several members of the family were already shown to be involved in ubiquitination (Toniato, Chen et al. 2002; Niikura, Hashimoto et al. 2003; Xu, Yang et al. 2003) and most of them are localized in particular cellular compartments (Reymond, Meroni et al. 2001).

TRIM3 (BERP) was identified through PCR based screening of the cerebellar cDNA as myosinV binding (El-Husseini and Vincent 1999) and alpha-actinin 4 binding (El-Husseini, Kwasnicka et al. 2000) protein with mainly cytoplasmic localization. 


\section{Results}

Structure of TRIM2 and TRIM3 proteins seems to be very similar with exactly the same size (744aa) and functional domains (RING finger, B-box, CC, NHL repeats) distributed in the same way in both the proteins (fig. 9). As the overall identity of the proteins on the amino-acid level is over 67\%, analysis of TRIM2 was carried out with regards to the already known properties of TRIM3 to see, whether even the molecular characteristics of both the proteins are similar.

\subsubsection{Intracellular localization of Trim2 and interaction with Myosin V}

Intracellular localization of TRIM2 protein was analyzed in in vitro transfection experiments. The mouse neuroblastoma cell line Neuro2a was selected as a well-characterized in vitro neuron-like model system and transfected with c-myc-tagged Trim2 fusion construct. The Trim2 Intracellular localization was analyzed by anti-c-myc antibodies (Santa Cruz) immunostaining.

Similar to TRIM3 intracellular localization (El-Husseini and Vincent 1999), TRIM2 seemed to be mainly but not exclusively cytoplasmic (Fig. 26) confirming results obtained by (Ohkawa, Kokura et al. 2001) in PC-12 cell line.

Mainly cytoplasmic localization of TRIM3 matches well with the also cytoplasmic localization of its binding partner - myosin V (El-Husseini and Vincent 1999) - a member of the nun-muscle molecular motor protein family (Mercer, Seperack et al. 1991). As TRIM3 c-terminal NHL repeats (responsible for the interaction with myosin V) are $81 \%$ identical to the NHL repeats of TRIM2 in the amino acid level, a possible interaction of TRIM3 protein with myosin $\mathrm{V}$ was tested by pull-down assays. 


\section{Results}

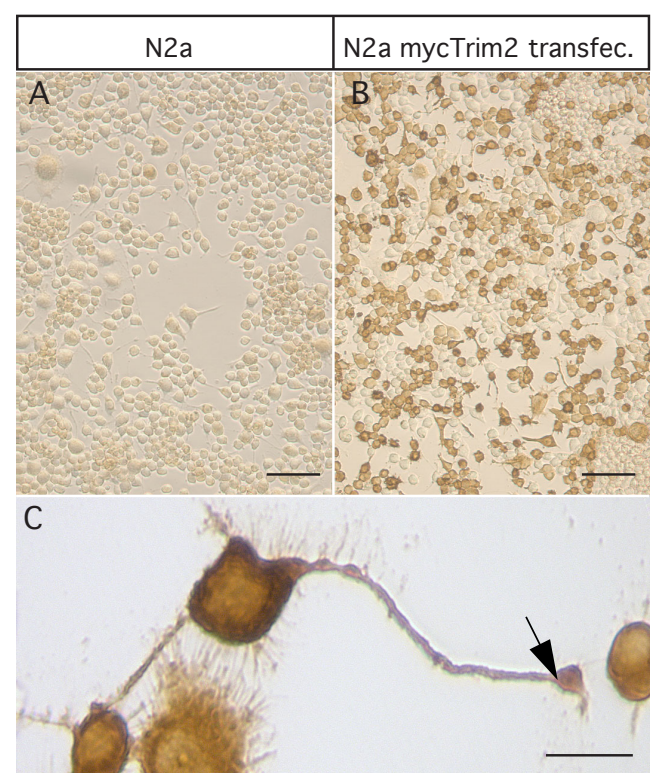

Fig. 26: Intracellular localization of myc-Trim2 fusion protein in Neuro2a cell line. Trim2 is localized mainly in cytoplasm (B, C) and neurites (C, arrow) of N2a cells. (A - untransfected cells.) Scale bars: A,B - $50 \mu \mathrm{m} ; \mathrm{C}-10 \mu \mathrm{m}$

The Neuro2a cell line was transfected with myc-TRIM2 fusion construct and after 1.5 days of cultivation protein extract was prepared from the cell lysate. The over-expressed myc-TRIM2 protein was then pulled down from the extract together with its binding partners with anti-c-myc beads (Santa Cruz). Myosin V was identified as one of the binding partners by western blotting with anti-myoV antibodies (kindly provided by P. Bridgman) (Fig. 27). Similar results were obtained by (Ohkawa, Kokura et al. 2001) in COS7 cells. 


\section{Results}

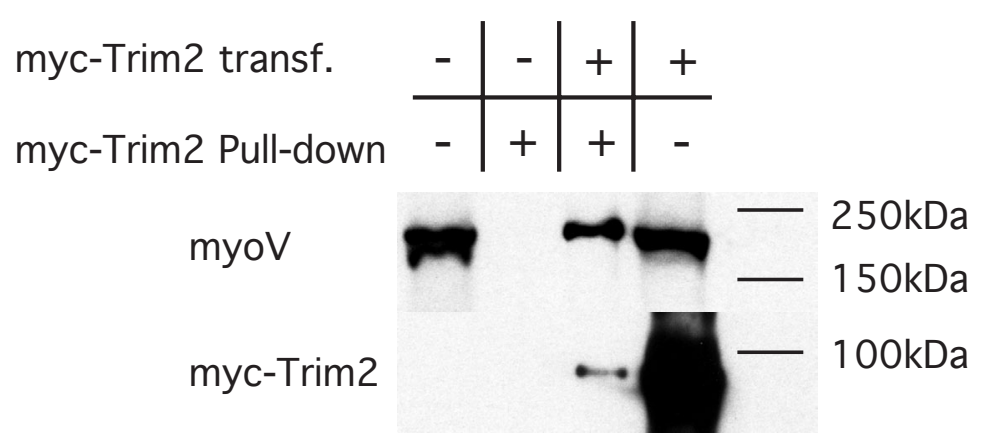

Fig. 27: Myosin V was shown to interact with Trim2 protein in vitro by pull-down assay. Myc-Trim2 fusion protein was transfected into N2a cell line and pulled down with anti-myc beads together with myosin V (detected with anti-myoV antibodies).

Many of the previously identified RING finger proteins have been recently related to ubiquitination as ubiquitin ligases, driving their binding partners towards proteasome degradation. Ubiquitination is currently considered as possible common function of RING finger proteins in general (Joazeiro and Weissman 2000). The same can be said about TRIM family of RING finger proteins where several members were recently also found to be involved in ubiquitination (Toniato, Chen et al. 2002; Niikura, Hashimoto et al. 2003; Xu, Yang et al. 2003).

Since myosin V was identified as one of the binding partners of TRIM2 protein, myo$\sin \mathrm{V}$ levels were analyzed in the Neuro2a cell line before and after myc-TRIM2 transfection. If the role of TRIM2 protein was regulation of myosin V intracellular levels, overexpression of TRIM2 should lead to increased degradation of myosin V in proteasome and subsequently decrease of its intracellular level as seen in other members of TRIM family (Niikura, Hashimoto et al. 2003). No such a phenomenon was observed in Western blotting analysis of the protein extracts of Neuro2a cells with anti-myoVa antibodies (Fig. 28) suggesting myosin $\mathrm{V}$ is not targeted by TRIM2 for proteasomal degradation. 


\section{Results}

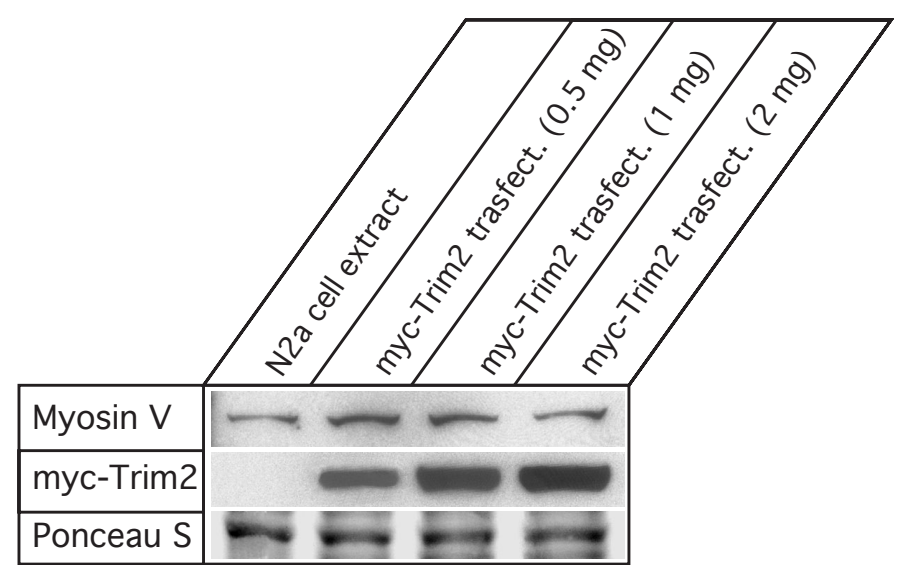

Fig. 28: Intracellular level of myosin V in N2a cell line is not affected by transfection of increasing concentrations of mycTrim 2 suggesting Trim 2 does not regulate intracellular levels of myosin V. Ponceau S protein staining was used as a loading controle.

\subsubsection{Electron microscopy of the Cerebellar PC spines}

The fact that Trim2 binds myosin $\mathrm{V}$ is very intriguing, since dysfunction of myosin $\mathrm{V}$ in mouse and rat (spontaneous mutation: dilute lethal - $\mathrm{dl}$ ) leads itself to a neurological defect, characterized by convulsions, opisthotonus, and ataxia apparent at 8-10 days of age and continuing until the death of the animals at 2-3 weeks of age (Mercer, Seperack et al. 1991). Importantly, even though no Purkinje cell degeneration was detected in the 3 weeks old dl mutants before their premature death, the smooth endoplasmic reticulum (SER) was found missing in dendritic spines of mutant Purkinje cells (Takagishi, Oda et al. 1996). Since SER is an important store of $\mathrm{Ca}$ ions in the spines, its absence delays Ca release after neuron stimulation leading to loss of long term depression in the parallel fiber synapses possibly causing the ataxic phenotype through deregulation or neuronal response (Miyata, Finch et al. 2000).

Because TRIM2 interacts with Myosin V and because Trim2 ${ }^{\mathrm{GT}}$ mutation leads to Purkinje cell degeneration and gait ataxias in mice, electron microscopic analysis of the Purkinje cell dendrites was carried out (in collaboration with MRC Anatomical Neurophar- 


\section{Results}

macology Unit University of Oxford) in order to see whether smooth endoplasmic reticulum is present in the spines of mutant Purkinje neurons.

No difference in the SER localization was detected in the spines of PC neurons (Fig. 29) indicating interaction between TRIM2 and Myosin V is not necessary for transport of SER into the dendritic spines.

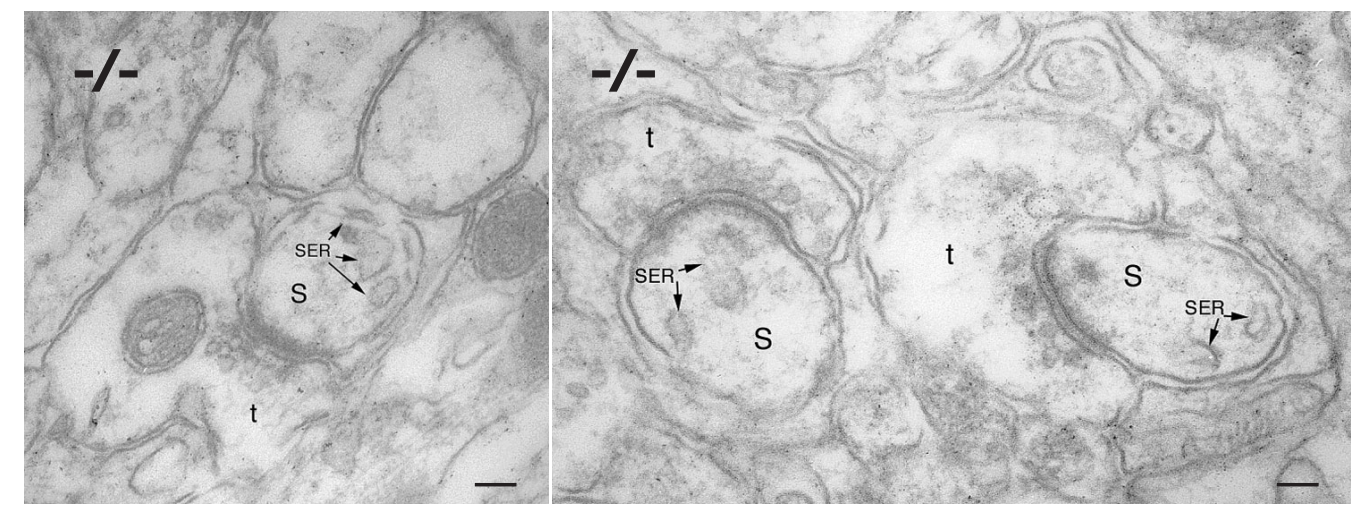

Fig. 29: Electron micrographs of the cerebellar molecular layer of the Trim2 $2^{\mathrm{GT}}$ mutants revealed presence of smooth endoplasmic reticulum (SER) in Purkinje cell spines (S) indicating Trim2 is not involved in SER transport. $\mathrm{t}$ - axon terminal. Scale bars $0.1 \mu \mathrm{m}$.

Since no major defect was observed in the mutant Purkinje dendrites, while axonal swellings were present even before the onset of the PC degeneration (1 month old homozygotes), we concluded that axonal defect could be the cause of cerebellar phenotype of Trim2 $2^{\mathrm{GT}}$ mutant mice. 


\section{Discussion}

\subsection{Discussion}

In the present thesis work, I have demonstrated that the product of gene Trim2 is essential for axonal homeostasis in the Purkinje cells of the mouse cerebellum, and that, most likely through its function in axonal transport, Trim 2 has a key role in the maintenance of the structure and function of the mouse cerebellum -deficiency in Trim2 is the cause of a progressive degeneration of the cerebellum that leads to an incapacitating tremor and ataxia condition comparable in clinical manifestations and prognosis to human cerebellar ataxia syndromes.

\subsection{Gene trap mutagenesis as tool of discovery}

In a first phase of my project I have worked in the context of a large scale gene trap mutagenesis screen designed for identification of genes involved in function and/or development of the mouse brain, and carried out in the department directed by Prof. Peter Gruss. Gene trap mutagenesis screens are an essential tool of proven efficacy in the analysis of the genome (Leighton, Mitchell et al. 2001).

From the output of this screen, I selected for analysis one mouse gene trap line with CNS restricted expression pattern and cloned, by a combination of reverse transcription PCR and screening of mouse E10.5 cDNA library, the gene disrupted by the gene trap vec- 


\section{Discussion}

tor insertion. It turned out to be a member of the RBCC/TRIM family of RING finger proteins which had been recently cloned also by (Ohkawa, Kokura et al. 2001) and received the name of TRIM2(NARF).

Trim2 was expressed in adult cerebellar Purkinje neurons, deep cerebellar nuclei, hippocampal CA1, CA2, CA3 pyramidal neurons, dentate gyrus granule cells, retinal ganglionic cells and inner nuclear layer neurons. These data were obtained by me first by beta-gal staining, and then confirmed by in situ hybridization using antisense riboprobes against Trim2 mRNA.

The phenotype of the mutation was analyzed in homozygous and heterozygous mice. Northern blotting of total RNA isolated from brains of homozygous animals revealed presence of ca. 5\% of the wild type transcript (compared to the level of expression in the WT animals) indicating the Trim2GT mutation creates a hypomorphic phenotype in homozygous mice. Hypomorphic phenotypes are common in insertional mutagenesis, as a result of alternative splicing (Letts, Felix et al. 1998; Salminen, Meyer et al. 2000). The fact that my mutants present a strong, very characteristic phenotype, even while carrying about $5 \%$ of the native protein testimonies to the functional relevance of Trim2.

\subsection{Trim 2 mutant phenotype shows similar clinical characteristics as human cerebellar ataxia syndromes}

Trim2GT homozygotes looked normal until the age of ca 1.5 months when they started to suffer from tremor followed by gait ataxias. Spontaneous episodic seizures added to the syndrome in older mutants (ca. 3 months of age). Analysis of the mutant cerebella revealed a progressive degeneration of Purkinje neurons and deep cerebellar nuclei starting around. postnatal day $(\mathrm{P}) 50$.

Since deafferentation is an important cause of neuronal death (Cowan, Fawcett et al. 1984), I analyzed the integrity of the main afferent axons to the Purkinje cells (the so-called climbing fibers) and of the cell bodies, located in the brainstem, from which they originate (inferior olivary complex). Inferior olivary somata showed normal numbers and appearance. The climbing fibers afferent to the degenerated areas disappeared, but the ones arriving to 


\section{Discussion}

(still) intact Purkinje cells made contacts with the dendrites, and had normal histological apperarance.

Very large and entirely unusual axonal swellings were discovered in Purkinje cells in both granular layer and white matter already in one-month old Trim2GT mutants. Since axonal swellings were the first sign of PC degeneration detected in Trim2GT mice they could indeed be the real cause of their degeneration.

\subsection{The mutant retina shows a particular kind of degeneration}

There are several classical cerebellar mouse mutants suffering from Purkinje cell degeneration and gait ataxias. They differ in the onset and severity of degeneration and number of cerebellar neurons affected (Grusser-Cornehls and Baurle 2001). Among the classical cerebellar syndromes, PCD (Purkinje cell degeneration) and nervous (Mullen, Eicher et al. 1976) share a high similarity with Trim2GT mutants regarding onset and type of degenerating cerebellar neurons. Since both develop also a slow progressing retinal degeneration, I analyzed the histology of the retina in Trim2 mutants and found degeneration in this tissue as well. Closer examination, though, revealed a unique pattern of degeneration of Trim2GT retinal neurons when compared to the PCD and nervous mutants. While ganglionic cell layer and inner nuclear layer are the most affected retinal layers in Trim2GT homozygote mice, the most severe degeneration in the PCD and nervous retinas was detected in the outer nuclear layer with photoreceptor cells (LaVail, Blanks et al. 1982; Chang, Hawes et al. 2002), making Trim2GT mice a unique model of cerebellar and retinal degeneration (Fig. 30). 


\section{Discussion}

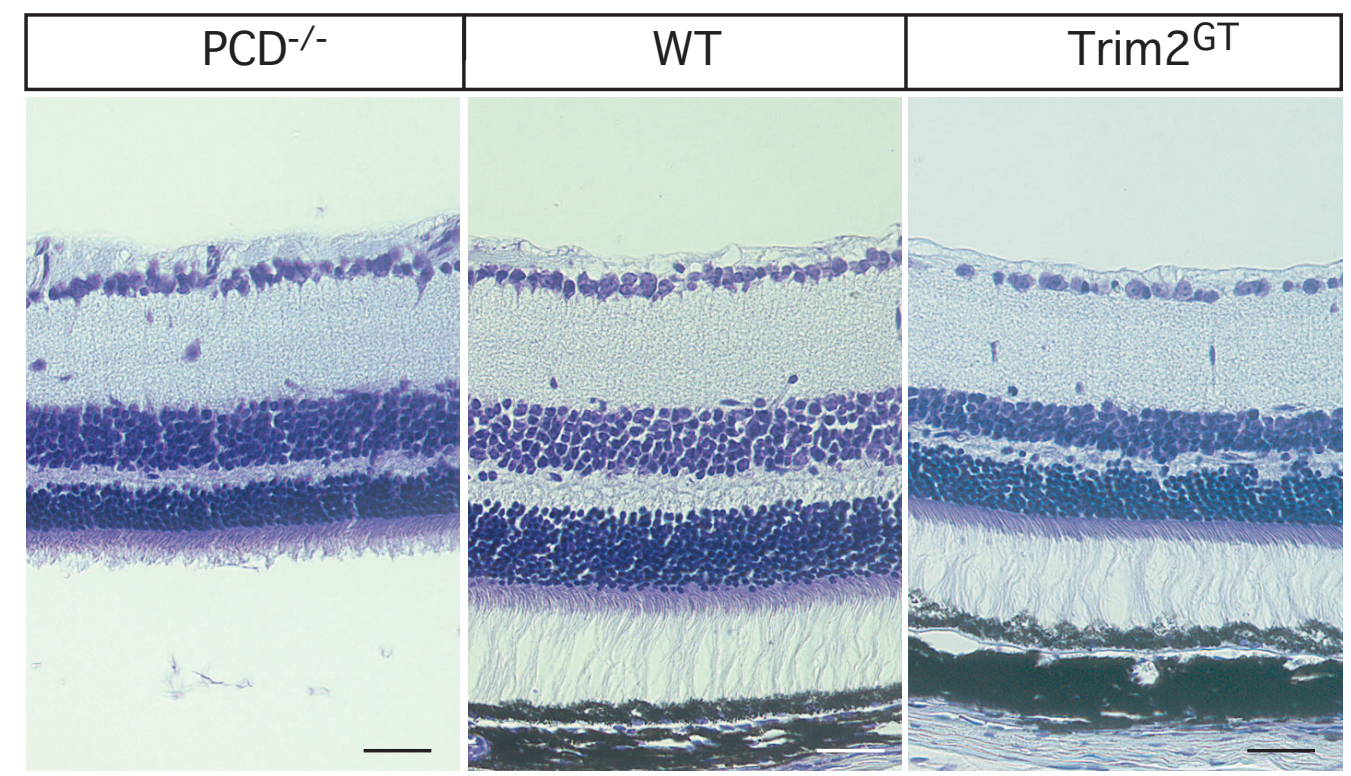

Fig. 30: Retinal degeneration in $\mathrm{PCD}^{-/-}$and Trim $2^{\mathrm{GT}}$ mice. The outer nuclear layer is the most affected in $\mathrm{PCD}^{-/-}$mice while in the Trim2 $2^{\mathrm{GT}}$ mice degeneration of ganglionic cell layer and inner nuclear layer is the most prominent. Scale bars $30 \mu \mathrm{m}$.

\subsection{Despite episodic seizures, the mutant hippocampus is normal}

Even though the highest expression of Trim 2 was detected in adult hippocampus, adult Trim2GT homozygotes (from 3 months of age) suffer from episodes of spontaneous seizures and kainate/PTZ kindling of rats was shown to up-regulate expression of Trim2 in hippocampus (Ohkawa, Kokura et al. 2001), no significant reduction of hippocampal neurons was observed in Trim2GT homozygotes.

Kainate and PTZ applied at convulsant doses can produce seizures and excitotoxicity accompanied by increased c-fos expression in rat and mouse hippocampus and cerebellum (Schauwecker, Ramirez et al. 2000; Pizoli, Jinnah et al. 2002).

c-fos immunostaining of Trim2GT hippocampi and cerebella did not show any increase in c-fos expression, suggesting seizures and Purkinje cell degeneration of Trim2GT mutant mice were not caused by excitotoxicity (not shown). 


\section{Discussion}

\subsection{TRIM2 interacts with MyosinV}

Next, I analyzed the binding properties of TRIM2 by means of the protein pull-down assay. Myosin V and alpha-actinin 4 - binding partners of TRIM3/BERP protein (almost $70 \%$ identical to TRIM2 on the amino acid level), were tested for interaction with TRIM2. While no interaction was detected in the case of alpha-actinin 4 (now shown), myosin $\mathrm{V}$ was pulled-down together with TRIM2 from protein cell-extract, as also recently demonstrated by (Ohkawa, Kokura et al. 2001).

Myosin V is a member of a large superfamily of motor proteins. It is involved in fast axonal/dendritic transport and the anterograde and retrograde movement of vesicles/ organelles in neurons. As an actin based molecular motor Myosin V was shown to transport smooth endoplasmic reticulum (SER) vesicles on cortical actin filaments in the giant squid axons (Tabb, Molyneaux et al. 1998), it has been detected on Golgi-derived secretory synaptic vesicles (Evans, Lee et al. 1998) and in the mouse and human melanocytes myosin V was found to be responsible for transport of large organelles - melonosomes ( $\mathrm{Wu}$, Bowers et al. 1998). Myosin V is required for transport of the SER to the dendritic spines of Purkinje neurons (Takagishi, Oda et al. 1996). Mice deficient in MyosinV, consequently, do not have SER in Purkinje dendrites; probably as a consequence they suffer from ataxia and opisthotonus (Mullen, Eicher et al. 1976) and die around postnatal day P20.

\subsection{Mechanisms of neural degeneration: 1) The Trim2-Myosin V-neu- rofilament connection}

I have discarded dendrite affectation in Trim 2 mutants by analyzing the ultrastructure of mutant Purkinje cell dendrites by electron microscopy. No difference in SER localization was seen in mutant PC dendrites when compared to the WT animals and even overall dendritic morphology of mutant PC (analyzed by confocal microscopy with anti-calbindin anbibodies) was not significantly different suggesting PC dendrites were not the primary site of Trim2GT pathology. In conclusion, the axonal swellings in Purkinje neurons (see above) where the only major histological alteration that could be found in mutant cerebel- 


\section{Discussion}

lum before massive degeneration took place. The "axonal hypothesis" revealed then to be very informative.

A major component of axonal cytoskeleton are the neurofilaments. Myosin $\mathrm{V}$ has recently been found to interact with neurofilament light chain (NF-L) subunit in mouse central and peripheral nervous tissue (Rao, Engle et al. 2002). Neurofilament density has been reported as significantly increased in axons of myosin $\mathrm{V}$ null mutant mice indicating myosin $\mathrm{V}$ plays a role in either rearrangements or transport of neurofilaments in axons in addition to its well-recognized role in translocating membranous organelles.

Neurofilament alterations have been linked to multiple neurodegenerative disorders accumulation of neurofilaments in the perikaryon and axons of motor neurons are associated with their degeneration in amyotrophic lateral sclerosis rev. (Robertson, Kriz et al. 2002). Mutations in NF-L were reported in Charcot-Marie-Tooth disease type 2 (Mersiyanova, Perepelov et al. 2000) and Parkinson's disease (Lavedan, Buchholtz et al. 2002). Perhaps most intriguingly, transgenic mice expressing mutant NF-L develop axonal swellings in Purkinje neurons (Gibb, Brion et al. 1998).

\subsection{Mechanisms of neural degeneration: 2) Ubiquitin ligases and neurofilaments as possible originators of neurodegenerative disease}

RING finger domain present in the N-terminus of Trim2 defines one group of E3 ubiquitin ligases the number of whose members is still increasing (Tyers and Jorgensen 2000). Defects in ubiquitination are involved in most of the neurodegenerative disorders. The accumulation of ubiquitin conjugates and ubiquitin containing inclusion bodies has long been known to occur in broad array of chronic neurodegenerative diseases. These include the neurofibrillary tangles of AD, Lewy bodies in both Parkinson's disease and Lewy body dementia, Bunina bodies in amyotrophic lateral sclerosis, and nuclear inclusions in CAG-repeat expansion disorders such as Huntington's disease and spinocerebellar ataxias (Alves-Rodrigues, Gregori et al. 1998). Beside the ubiquitin inclusions, ubiquitination has been shown to cause neurodegenerative disorders or neurological defects in even more direct way: mutation in RING finger protein Parkin was found in the juvenile form of 


\section{Discussion}

Parkinson's disease (Shimura, Hattori et al. 2000), mutation in ubiquitin specific protease Usp14 causes synaptic defects in "ataxia" mice (Wilson, Bhattacharyya et al. 2002), tripartite motif protein TRIM11 was found to destabilize Humanin - a neuroprotective peptide against Alzheimer's disease likely through proteasome degradation (Niikura, Hashimoto et al. 2003).

The fact that the intracellular level of the binding partner of Trim2 (Myosin V) has not been shown to be regulated by increasing levels of Trim2, does not exclude Trim 2 involvement in ubiquitination. The part of TRIM2 protein responsible for interaction with myoV was found in the C-terminus where NHL repeats are present (Ohkawa, Kokura et al. 2001). Since other TRIM RING finger proteins shown to drive their binding partner to degradation - TRIM11, TRIM9 (Toniato, Chen et al. 2002; Niikura, Hashimoto et al. 2003) interact with them through their RING finger domain, it is conceivable that a protein interacting with TRIM2 through its RING finger domain would be driven by TRIM2 to proteasome degradation.

\subsection{Conclusion}

In the current work I have succeeded to link for the first time deficiency in RING finger protein TRIM2 to a progressive and degenerative ataxia syndrome, with juvenile onset. Additionally, I have shown that the cause of this phenotype is an axonal transportation defect specific of cerebellar Purkinje cells, whose likely origin can be found in the functional relation between TRIM2 and myosin V, which is essential for correct axonal transport. I have shown the Trim 2 mutant mouse to be a model for the study of cerebellar ataxias, and with its help I have gathered evidence towards a molecular mechanism for the origin of such pathological conditions, additionally identifying RING finger proteins as potential target candidates for pharmacological drugs, which could alleviate this type of conditions in human patients. 


\subsection{Abbreviations and Symbols}

$\begin{array}{ll}\text { aa } & \text { amino acid } \\ \text { Amp } & \text { ampicillin } \\ \text { AP } & \text { alkaline phosphatase } \\ \text { Ab } & \text { antibodies } \\ \text { APS } & \text { ammoniumpersulfate } \\ \text { ATP } & \text { adenosintriphosphate } \\ \text { bp } & \text { base pare } \\ \text { c } & \text { centi } \\ { }^{\circ} \mathrm{C} & \text { degree(s) of Celsius } \\ \text { ca. } & \text { circa } \\ \text { CC } & \text { coiled coil } \\ \text { Ci } & \text { Curie } \\ \text { cDNA } & \text { complementary DNA } \\ \text { cM } & \text { centi Morgan } \\ \text { CNS } & \text { central nervous system } \\ \text { cpm } & \text { counts per minute } \\ \text { CTP } & \text { cytidintriphosphate }\end{array}$




\section{Abbreviations and Symbols}

\begin{tabular}{|c|c|}
\hline dATP & desoxyadenosintriphosphate \\
\hline dCTP & desoxycytidintriphosphate \\
\hline dGTP & desoxyguanosintriphosphate \\
\hline dTTP & desoxythymidintriphosphate \\
\hline dNTP & desoxyukleotidtriphosphat \\
\hline DEPC & diethylpyrocarbonate \\
\hline dil. & dilution \\
\hline DMSO & dimethylsulfoxide \\
\hline DNA & deoxyribonucleic acid \\
\hline DTT & dithiothreitol \\
\hline E.coli & Escherichia coli \\
\hline EDTA & ethylendiamin-N,N, $\mathrm{N}^{\prime}, \mathrm{N}^{\prime}$-tetra acetic acid \\
\hline ES & embryonic stem (cells) \\
\hline est & expressed sequence tags \\
\hline $\mathrm{EtOH}$ & ethanol \\
\hline FCS & fetal calf serum \\
\hline $\mathrm{g}$ & gram \\
\hline GT & gene trap \\
\hline GTP & guanosintriphosphate \\
\hline h & hour(s) \\
\hline HEPES & 2-[4-(2-Hydroxyethyl)-1-piperazino]-ethansulfonic acid \\
\hline HRP & horseradish peroxidase \\
\hline IPTG & isopropyl- $\beta$-D-thiogalaktoside \\
\hline $\mathrm{kb}$ & kilobase pare (1000bp) \\
\hline$\mu$ & micro \\
\hline M & molarity (mol/l) \\
\hline MAB & monoclonal anitibody \\
\hline $\mathrm{MeOH}$ & methanol \\
\hline $\min$ & minute(s) \\
\hline
\end{tabular}




\section{Abbreviations and Symbols}

$\begin{array}{ll}\text { MOPS } & \text { 3-N-morpholinopropansulfonic acid } \\ \text { mRNA } & \text { messenger RNA } \\ \text { Mw } & \text { molecular weight } \\ \text { n } & \text { nano } \\ \text { NP-40 } & \text { Nonidet (non-ionic detergent) P-40 } \\ \text { OD } & \text { optical density } \\ \text { ON } & \text { overnight } \\ \text { ORF } & \text { open reading frame } \\ \text { PAB } & \text { polyclonal antibody } \\ \text { PAGE } & \text { polyacrylamid gel electrophoresis } \\ \text { PBS } & \text { phosphate-buffered saline } \\ \text { PC } & \text { Purkinje cell } \\ \text { PCR } & \text { polymerase chain reaction } \\ \text { PEG } & \text { polyethylenglycole } \\ \text { PFA } & \text { uridin triphosphate } \\ \text { PFU } & \text { tripartite motif (containing protein) } \\ \text { PVP } & \text { trichydroxymethyl)-amino methane } \\ \text { RACE } & \text { plaque forming unit } \\ \text { RNA } & \text { polyvinylpyrrolidone } \\ \text { RPM } & \text { rapid amplification of cDNA ends } \\ \text { RT } & \text { ribonucleic acid } \\ \text { SDS } & \text { rotations per minute } \\ \text { sec } & \text { trium dodecylsulfate } \\ \text { TCA } & \text { TEMED }\end{array}$


Abbreviations and Symbols

$\begin{array}{ll}\text { UTR } & \text { untranslated region } \\ \text { v/v } & \text { volume/volume } \\ \text { w/v } & \text { weight /volume } \\ \mathrm{x} & \text { times }\end{array}$




\subsection{Material and Methods}

\subsection{Organisms}

\subsubsection{Mice}

The mouse strains NMRI and C57BI/6/xSJL were obtained from Zentralinstitut für Versuchstierzucht in Hannover

\subsubsection{Bacterias}

E. coli-strain DH5 $\alpha$ (Hanahan 1983): (supE $44 \Delta$ lac U169 (Ф 80 lacZ $\Delta$ M15) hsdR 17 recA 1 endA 1 gyrA 96 thi-1 relA1), was used for construction and amplification of the plasmids.

XL1-Blue MRF', (Stratagene) $\Delta$ (mcrA) $183 \Delta$ (mcrCB-hsdSMR-mrr) 173 endA 1 supE44 thi-1 recA1 gyrA96 relA1 lac [F'proAB lacI ${ }^{\mathrm{q}} \mathrm{ZDM} 15$ Tn10 $\left(\mathrm{Tet}^{\mathrm{r}}\right)$ and C600 $\boldsymbol{H} \boldsymbol{f}$ (Clontech) were used for screening of the phage cDNA libraries. 


\section{Material and Methods}

\subsection{Material}

\subsubsection{Chemicals}

If not mentioned otherwise the chemicals used were purchased from companies: AMRESCO (Ohio, USA), J.T. Baker (Deventer, Holland), BRL (Bethesda Research Laboratories, Karlsruhe), Difco Laboratories (Detroit, USA), Fluka (Buchs, Schweiz), Merck (Darmstadt), Roth (Karlsruhe), Serva (Heidelberg), and Sigma (München). All chemical were of analytical grade: ,p.a.”

\subsubsection{Radiochemicals}

The used radiochemicals were purchased from the company Amersham-Buchler (Braunschweig).

\subsubsection{Plastic material}

The plastic material was purchased from companies Sarstedt, Eppendorf, Falcon, Greiner und Nunc

\subsubsection{Enzymes}

The enzymes were purchased from companies SERVA/Promega (Heidelberg), New England Biolabs (Bad Schwalbach), Roche (Mannheim), Gibco-BRL (Karlsruhe), Amersham-Buchler (Braunschweig), Pharmacia Biotech. (Freiburg) Stratagene (La Jolla, Kalifornien, USA) und GeneCraft (Münster).

\subsubsection{Membranes}

Uncharged nylon membranes used for transfer of DNA and RNA and hybridization were purchased from companies Qiagen (Düsseldorf) or PAL.

For electrotransfer of proteins Immobilon-P membranes purchased from company Millipore were used . 


\section{Material and Methods}

\subsubsection{Films}

Kodak Extrachrome 160T film was used for taking pictures in Zeiss Axiophot microscope.

For autoradiography Biomax, MR (Kodak) films were used, radioactive in situ hybridization was done with Kodak NTB-2 liquid film.

\subsubsection{Vectors}

pBluescript II KS+ (Stratagene): Was used as universal vector for cloning of DNA fragments, for sequencing and transcription of RNA probes for in situ hybridization.

PGEM-T easy (Promega): Was used as vector for cloning of PCR amplified fragments containing $\mathrm{T}$ overhangs, for sequencing and transcription of RNA probes for in situ hybridization.

pCS2+MT (Rupp, Snider et al. 1994): Was use for overexpression of N-terminally tagged (6x Myc epitop) proteins in in vitro cultured cells

pBS-TRIM2-1.1: pBS II KS+ with cloned 1.1kb EcoRI-HindIII TRIM2 UTR fragment. The vector was used for production of probes for nonradioactive in situ hybridization.

pGEM-TRIM2-0.6: pGEM-T easy with cloned $0.6 \mathrm{~kb}$ TRIM2 coding fragment (nucleotides $745-1387$ of the TRIM2 transcript). The vector was used for production of probes for radioactive and nonradioactive in situ hybridization.

\subsubsection{Oligo-desoxy-ribonukleotides}

The used olinonucleotides were purchased from company NAPS (Göttingen) 


\title{
Material and Methods
}

\subsubsection{Antibodies}

\author{
Primary antibodies: \\ -polyclonal \\ rabbit-anti-inosito 1,4.5-trisphosphate receptor type I (1:50, Sigma) \\ rabbit-anti-MyosinV (1:4000) kindly provided by P.Bridgman (St. Louis) \\ guinea pig-anti-vesicular glutamate transporter 2 (1:1500, Chemicon) \\ rabbit-anti-alpha actinin 4 (1:1500, ImmunoGlobe) \\ rabbit-anti-cFos (1:1500, Sigma) \\ rabbit anti-tyrosine hydroxylase (chemicon): 1/300 \\ -monoclonal \\ anti-cMyc(9E10) (1:1000, Santa Cruz) \\ anti-cMyc(9E10) agarose beads (Santa Cruz) \\ anti-FLAG(M2) (1:1000, Sigma) \\ anti-calbindin (1:50, Sigma) \\ anti-parvalbumin (1:500, Chemicon) \\ anti-calretinin (1:100, Chemicon)
}

\section{Secondary antibodies:}

Goat-anti-mouse-HRP and goat-anti-rabbit-HRP conjugates (Dianova) were used as secondary Ab for protein detection on western blots together with SuperSignal West Dura Extended Duration Substrate (Pirce).

In immunohistochemistry either HRP based detection system "Vectastain ABC kit" (Vector Laboratories, Burlingame) or fluorophor-conjugated antibodies (MoBiTec, dil. $1: 300)$ were used. 


\section{Material and Methods}

Green emission: alexa488-conjugated - goat-anti-mouse IgG

- goat-anti-rabbit IgG

Red emission: alexa594-conjugated - goat-anti-mouse IgG

- goat-anti-rabbit IgG

\subsubsection{Computer analysis}

For analysis of the obtained sequences and alignment of the found ORF as well as for search for protein domains present in the deduced amino acid sequences, following computer programs and algorithms were used: BLAST (Altschul, Gish et al. 1990), CLUSTAL (Thompson, Higgins et al. 1994), SMART (Schultz, Milpetz et al. 1998; Schultz, Copley et al. 2000) Pfam (Bateman, Birney et al. 2000)

\subsubsection{Media}

\section{a) Bacterial}

LB (Luria-Bertani) medium: 0.5\% (w/v) Bacto-Yeast-Extract, 1\% (w/v) Bacto-Tryptone, $1 \%(\mathrm{w} / \mathrm{v}) \mathrm{NaCl}$. $\mathrm{pH}$ was adjusted to 7.0 with $\mathrm{NaOH}$ and the medium was autoclaved.

LB agar: contained additional $1.5 \%(\mathrm{w} / \mathrm{v})$ agar.

LB agar ampicillin: The LB-Medium with 1,5\% (w/v) agar was after the autoclaving chilled down to $50^{\circ} \mathrm{C}$ and Ampicillin was added to the final concentration of $100 \mathrm{mg} / \mathrm{ml}$.

NZY medium: $0.5 \%(\mathrm{w} / \mathrm{v}) \mathrm{NaCl}, 0.2 \%(\mathrm{w} / \mathrm{v})$ magnesium sulfate, $0.5 \%(\mathrm{w} / \mathrm{v})$ bactoyeast- extract, $0,1 \%(\mathrm{w} / \mathrm{v})$ casein hydrolysate. $\mathrm{pH}$ was adjusted to 7.0 with $\mathrm{NaOH}$ and the medium was autoclaved.

NZY agar: contained additional 1.5\% (w/v) agar. 


\section{Material and Methods}

TOP agarose: $0.7 \%(\mathrm{w} / \mathrm{v})$ agarose, in NZY medium. The medium was autoclaved and shortly before the use put in a $50^{\circ} \mathrm{C}$ water bath.

\section{b) For the cell culture}

The N2a cells were grown in DMEM medium with $4,5 \mathrm{mg} / \mathrm{ml}$ glucose (GIBCO, BRL), with addition of $10 \%$ heat inactivated FCS (30min., $56^{\circ} \mathrm{C}$ ) and mixture of antibiotics (100U/ml penicillin, 100 $\mathrm{gg} / \mathrm{ml}$ streptomycin).

\subsubsection{Buffers}

\section{Acetylation Mix:}

$0.1 \mathrm{M}$ Triethanolamin,

$0.05 \mathrm{M}$ acetanhydrid.

The solution was made shortly before use.

\section{Acrylamid solution:}

$29.2 \%(w / v)$ Acrylamid

$0.8 \%(\mathrm{w} / \mathrm{v})$ Methylenbisacrylamid

dissolved in $\mathrm{H}_{2} \mathrm{O}$ and filtered

\section{Ampicillin:}

The Natrium salt was dissolved in $\mathrm{H}_{2} \mathrm{O}$ to the final concentration $50 \mathrm{mg} / \mathrm{ml}$, sterilized by filtration and stored at $-20^{\circ} \mathrm{C}$.

\section{APS-solution:}

$10 \%(\mathrm{w} / \mathrm{w})$ Ammoniumpersulfat in $\mathrm{H}_{2} \mathrm{O}$ aliquoted and stored at $-20^{\circ} \mathrm{C}$ 


\section{Material and Methods}

\section{Chlorophorm/Isoamylalkohol:}

Chlorophorm and Isoamylalkohol was mixed in the ratio 24:1

Coomassie Blue staining solution:

$50 \%(\mathrm{v} / \mathrm{v})$ methanol

$10 \%(\mathrm{v} / \mathrm{v})$ acetic acid

$0.25 \%$ (w/v) Coomassie Blue R-250

Coomassie Blue destaining solution I:

$50 \%(\mathrm{v} / \mathrm{v})$ methanol

$12 \%(\mathrm{v} / \mathrm{v})$ acetic acid

Coomassie Blue destaining solution II:

$12 \%(\mathrm{v} / \mathrm{v})$ acetic acid

DAB staining solution:

$0.3 \%$ hydrogen peroxide

0.3 M diaminobenzidine in PBS

\section{Denaturing solution}

\section{$1.5 \mathrm{M} \mathrm{NaCl}$}

$0.5 \mathrm{M} \mathrm{NaOH}$

Developing solution for protein silver staining:

$60 \mathrm{~g} / 1 \quad \mathrm{Na}_{2} \mathrm{CO}_{3}$

$0.0185 \%$ formaldehyde

$16 \mathrm{mM} \mathrm{Na}_{2} \mathrm{~S}_{2} \mathrm{O}_{3}$

DEPC treated H2O: 


\section{Material and Methods}

11 distilled water was incubated overnight at $37^{\circ} \mathrm{C}$ on shaker with $1 \mathrm{ml}$ diethyl pyrocarbonate (DEPC) and autoclaved.

\section{M DTT:}

DTT was diluted in $\mathrm{H}_{2} \mathrm{O}$ to final concentration $1 \mathrm{M}$ and stored at $-20{ }^{\circ} \mathrm{C}$

\section{Ethidiumbromid solution:}

Ethidiumbromid was diluted to the final concentration $10 \mathrm{mg} / \mathrm{ml}$ in water and stored at $4{ }^{\circ} \mathrm{C}$.

Fixative solution for brain perfusions:

$0.1 \mathrm{M}$ phosphate buffer $\mathrm{pH} 7.4$

$4 \%$ paraformaldehyde

$0.2 \%$ picric acid

( $0.05 \%$ glutaraldehyde - only for electron micr.)

Fixative solution for protein silver staining:

$50 \%$ methanol

$12 \%$ acetic acid

\section{Giemsa - working dilution:}

$20 \mathrm{ml}$ of Giemsa - stocksolution and $10 \mathrm{ml}$ of $0.2 \mathrm{M}$ Natrium phosphate buffer $\mathrm{pH} 6.0$ was diluted in $500 \mathrm{ml} \mathrm{H}_{2} \mathrm{O}$ and filtered before use.

\section{Giemsa - stock solution:}

$0.8 \%(w / v)$ Giemsa (Sigma)

$50 \%(\mathrm{v} / \mathrm{v})$ Glycerol

$50 \%(\mathrm{v} / \mathrm{v})$ Methanol

The solution was dissolved overnight on a shaker at $37^{\circ} \mathrm{C}$. 


\section{Material and Methods}

Hybridization mix (non-radioactive in situ hybridization):

$50 \%$ formamid

$5 \mathrm{x}$ SSC

$1 \%$ Blocking reagent (Roche) in $\mathrm{H}_{2} \mathrm{O}$ (dissolved at $65^{\circ} \mathrm{C}$ )

$5 \mathrm{mM}$ EDTA

$0.1 \%$ Tween-20

$0.1 \%$ CHAPS

$0.1 \mathrm{mg} / \mathrm{ml}$ heparine

$1 \mathrm{mg} / \mathrm{ml}$ yeast total RNA

$5 \mu l$ probe added to $995 \mu l$ hybridization mix (probe concentration around $1 \mu \mathrm{g} / \mathrm{ml}$ ).

Before use heat the probe $5 \min 95^{\circ} \mathrm{C}$ and keep on ice.

Hybridization buffer (radioactive in situ hybridization):

1x Hybridization salt

$50 \%(\mathrm{v} / \mathrm{v})$ Formamide

$0.1 \mathrm{M}$ DTT

$10 \%$ Dextran-sulfate

10xHybridization salt (radioactive in situ hybridization):

$0.2 \%(\mathrm{w} / \mathrm{v})$ PVP (Polyvinylpyrrolidon)

$0.2 \%(\mathrm{w} / \mathrm{v})$ Ficoll

$0.1 \mathrm{M}$ Tris/ $\mathrm{HCl}, \mathrm{pH} 8.0$

50mM EDTA, pH8.0

0.1M Natrium-Phosphate buffer, pH6.8

$3 \mathrm{M} \mathrm{NaCl}$

Impregnation solution for protein silver staining:

$2 \mathrm{~g} / \mathrm{l} \mathrm{AgNO}_{3}$ 


\section{Material and Methods}

$0.026 \%$ formaldehyde

\section{IPTG $100 \mathrm{mM}$ solution:}

$0.5 \mathrm{~g}$ IPTG was diluted in $20 \mathrm{ml} \mathrm{H}_{2} \mathrm{O}$, sterilized, aliquoted and stored at $-20{ }^{\circ} \mathrm{C}$.

KTBT:

0.05M Tris- $\mathrm{Cl}$

$0.15 \mathrm{M} \mathrm{NaCl}$

$0.01 \mathrm{M} \mathrm{Kcl}$

1\% TritonX100

Lambda dilution buffer (1x)

$0.1 \mathrm{M} \mathrm{NaCl}$

$10 \mathrm{mM} \mathrm{MgSO}_{4} \times 7 \mathrm{H}_{2} \mathrm{O}$

35mM TrisCl pH 7.5

autoclaved

\section{Lysis buffer:}

$100 \mathrm{mM}$ TrisHCl pH 8.5

5 mM EDTA

$0.2 \%$ SDS

$200 \mathrm{mM} \mathrm{NaCl}$

$100 \mu \mathrm{g} / \mathrm{ml}$ Proteinase K

Mowiol - mounting medium:

9.6g Mowiol and 24g Glycerol was dissolved in $24 \mathrm{ml} \mathrm{H}_{2} \mathrm{O}$ on a stirrer for ca. 1 hour. Afterwards $48 \mathrm{ml}$ of $0.2 \mathrm{M}$ Tris/ $\mathrm{HCl} \mathrm{pH} 8.5$ was added to the solution and dissolved at $50^{\circ} \mathrm{C}$. The solution was briefly centrifuged $(1000 \mathrm{~g})$ to separate the undissolved particles, aliquoted and stored at $-20^{\circ} \mathrm{C}$. 


\section{Material and Methods}

Neutralization solution:

$1.5 \mathrm{M} \mathrm{NaCl}$

$0.5 \mathrm{M}$ Tris/ $\mathrm{HCl} \mathrm{pH} 7.5$

Neutralization solution (phage library screening):

$1.5 \mathrm{M} \mathrm{NaCl}$

$0.5 \mathrm{M}$ Tris/ $\mathrm{HCl} \mathrm{pH8,0}$

NTMT:

$100 \mathrm{mM}$ Tris-Cl

$100 \mathrm{mM} \mathrm{NaCl}$

$50 \mathrm{mM} \mathrm{MgCl} 2$

$0.05 \%$ Tween-20

$2 \mathrm{mM}$ levamisole $(0.48 \mathrm{mg} / \mathrm{ml})$ added fresh on day of use

NTE-Puffer:

$0.5 \mathrm{M} \mathrm{NaCl}$

$10 \mathrm{mM}$ Tris/HCl $\mathrm{pH} 7.5$

5mM EDTA pH8.0

The solution was autoclaved and before use warmed up to $37^{\circ} \mathrm{C}$.

4\% Paraformaldehyde (PFA)/PBS:

$8 \mathrm{~g}$ of PFA was dissolved in $190 \mathrm{ml} 60^{\circ} \mathrm{C} \mathrm{H} 2 \mathrm{O}$ on a magnetic stirrer with a drop of $10 \mathrm{M} \mathrm{NaOH}$. After $10 \mathrm{ml}$ of $20 \mathrm{x}$ PBS was added, the solution was kept at $4^{\circ} \mathrm{C}$. For insitu hybridization $\mathrm{pH}$ of the buffer was adjusted to 7.4.

PBS (phosphate buffered saline):

$140 \mathrm{mM} \mathrm{NaCl}$ 


\section{Material and Methods}

$10 \mathrm{mM} \mathrm{KCl}$

$6.4 \mathrm{mM} \mathrm{Na}_{2} \mathrm{HPO}_{4}$

$2 \mathrm{mM} \mathrm{KH}_{2} \mathrm{PO}_{4}$

PBS-T:

PBS $+0.1 \%$ TritionX100

PBT:

PBS $+0.1 \%$ Tween-20

Phage lysis buffer:

100mM Tris/HCl, $\mathrm{pH} 7.5$

$5 \mathrm{mM}$ EDTA

$0.5 \%(\mathrm{w} / \mathrm{v}) \mathrm{SDS}$

$200 \mathrm{mM} \mathrm{NaCl}$

$0.4 \mu \mathrm{g} / \mu \mathrm{l}$ Proteinase K (shortly before used)

\section{Phenol/Chlorophorm/Isoamylalkohol:}

The mixture of Phenol, Chlorophorm and Isoamylalkohol in ratio 25:24:1 (AMRESCO).

\section{Ponceau S Destaining solution:}

$40 \%$ methanol

$7 \%$ acetic acid

\section{Ponceau S solution:}

$0.5 \%$ Poncea $\mathrm{S}$ in $1 \%(\mathrm{v} / \mathrm{v})$ acetic acid solution

Proteinase K (stock solution): 


\section{Material and Methods}

Proteinase K (Roche) was diluted to a final concentration of $10 \mathrm{mg} / \mathrm{ml}$ in $50 \mathrm{mM}$ Tris-

$\mathrm{Cl}, \mathrm{pH} 8+5 \mathrm{mM}$ EDTA solution and stored in small aliquots at $-20^{\circ} \mathrm{C}$

Proteinase K working dilution (radioactive in situ hybridization):

20mM Tris/HCl, $\mathrm{pH} 7.5$

$1 \mathrm{mM}$ EDTA pH8.0

$20 \mu \mathrm{g} / \mathrm{ml}$ Proteinase K

The solution was made shortly before use.

Proteinase K working dilution (non-radioactive in situ hybridization):

$50 \mathrm{mM}$ Tris/ $\mathrm{HCl}, \mathrm{pH} 8$

5mM EDTA, pH8.0

$20 \mu \mathrm{g} / \mathrm{ml}$ Proteinase K

The solution was made shortly before use.

Protein sample buffer (2x):

$4 \%$ SDS

$10 \%$ Glycerol

$0.006 \%$ Bromphenol blue

$2 \% \beta$-mercaptoethanol

$250 \mathrm{mM}$ Tris-Cl pH 6.8

\section{RNase A:}

RNase A (Boheringer, Mannheim) was dissolved in $10 \mathrm{mM}$ Tris/ $\mathrm{HCl} \mathrm{pH} 7.5,15 \mathrm{mM}$ $\mathrm{NaCl}$ to a final concentration of $10 \mathrm{mg} / \mathrm{ml}$. The DNases were inactivated at $95^{\circ} \mathrm{C}$ for 15 min and chilled down to the room temperature. The solution was stored at $-20^{\circ} \mathrm{C}$.

\section{Running buffer for Western blotting (pH 8.3):}

$25 \mathrm{mM}$ Tris-base 


\section{Material and Methods}

$192 \mathrm{mM}$ glycine

$0.1 \%$ SDS

SM buffer:

$100 \mathrm{mM} \mathrm{NaCl}$

$10 \mathrm{mM}$ magnesium sulfat

50mM Tris/HCl, $\mathrm{pH} 7.5$

$0,01 \%(\mathrm{w} / \mathrm{v})$ gelatine.

$\operatorname{SSC~(1x):~}$

$0.15 \mathrm{M} \mathrm{NaCl}$

0.015M NaCitrat, $\mathrm{pH} 7.0$

10X TBE:

$0.89 \mathrm{M}$ Tris-Borat

0.89M Boric-acid

25mM EDTA pH8.0

$\mathrm{T}_{10} \mathrm{E}_{\mathbf{0 . 1}}$ :

10mM Tris/HCl, $\mathrm{pH} 7.4$

$0.1 \mathrm{mM}$ EDTA pH8.0

Transcription buffer (for nonradioactive in situ hybridization):

$1 \mu 1$ linearized plasmide DNA $(1 \mu \mathrm{g} / \mu \mathrm{l})$

$2 \mu l$ 10x RNase buffer (Roche)

$2 \mu l$ 10x DIG RNA labeling mix (Roche)

$0.5 \mu l$ Rnasin $(100 \mathrm{U} / \mu \mathrm{l})$

$14 \mu \mathrm{l}$ DEPC treated $\mathrm{H}_{2} \mathrm{O}$

$1 \mu \mathrm{l}$ RNA polymerase $(20 \mathrm{U} / \mu \mathrm{l})$ 


\section{Material and Methods}

Transcription mix (radioactive in situ hybridization)

$1 \mu l$ linearized template DNA $(1 \mu \mathrm{g} / \mu \mathrm{l})$

1 $\mu$ l 10xTranskription buffer (Roche)

$1 \mu 1$ ATP / GTP / CTP - Mix (10mM)

$2 \mu \mathrm{l}[\alpha]_{35} \mathrm{~S}-\mathrm{UTP}(40 \mathrm{mCi} / \mathrm{ml})$ (Amersham)

$4 \mu 1$ water

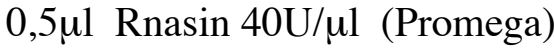

0,5 $\mu \mathrm{l}$ T3- or T7-RNA-Polymerase 20U/ $\mu$ (Roche)

Transfer buffer (for Western blotting):

20mM Tris-Base

150mM Glycine

$20 \%(\mathrm{v} / \mathrm{v})$ Methanol 


\section{Material and Methods}

\subsection{Molecular biology techniques}

\subsubsection{Isolation of the genomic DNA}

For genomic DNA isolation from mouse tails method described in (Laird, Zijderveld et al. 1991) was used. Briefly: mouse tails were overnight incubated at $55^{\circ} \mathrm{C}$ in lysis buffer. Tubes were vortexed and spun 10 min. $13000 \mathrm{rpm}$ (Heraeus, biofuge pico). Supernatant containing DNA was precipitated by addition of isopropanol to the final concentration $50 \%$. Precipitated DNA was spun down (13000 rpm, $10 \mathrm{~min}$, Heraeus, biofuge) washed in 70\% ethanol and resuspended in $100-300 \mu$ of $\mathrm{T}_{10} \mathrm{E}_{0.1}$ buffer at $44^{\circ} \mathrm{C}$ overnight.

\subsubsection{Labeling of DNA probe with ${ }^{32} \mathrm{P}-\alpha-\mathrm{dCTP}$}

$50 \mu \mathrm{g}$ of linearized dsDNA was denatured for $5 \mathrm{~min}$. at $95^{\circ} \mathrm{C}$, chilled down on ice for 1 minute, so as to prevent renaturation, and used for labeling reaction with Klenow enzyme in a labeling mix containing $50 \mu \mathrm{Ci}{ }^{32} \mathrm{P}-\alpha$-dCTP labeled nucleotides (Multiprime DNA Labelling kit, Amersham). Unincorporated nucleotides were removed with Sephadex G-50 Columns (ProbeQuantTM G-50 Micro Columns - Pharmacia Biotech) and $10^{6} \mathrm{cmp}$ of the probe was used per $1 \mathrm{ml}$ hybridization solution.

\subsubsection{Southern blotting}

$10 \mu \mathrm{g}$ genomic DNA was overnight digested with BamHI restriction endonuclease and fragments electrophoreticaly separated on $0.7 \%$ agarose (Gibco) gel (cca $1.5 \mathrm{~V} / \mathrm{cm}$ ). Gel was first depurinated for $15 \mathrm{~min}$. in $0.3 \mathrm{M} \mathrm{HCl}$ and then denatured in denaturing solution $(1.5 \mathrm{M} \mathrm{NaCl}, 0.5 \mathrm{M} \mathrm{NaOH})$ for $20 \mathrm{~min}$. Denatured gel was incubated for $20 \mathrm{~min}$. in Neutralization solution (1.5M NaCl, $0.5 \mathrm{M}$ TrisCl, $\mathrm{pH} 7.5)$ and DNA was transferred with $20 \mathrm{x}$ SSC buffer via capillary forces on a nylon membrane (Quiagen) as described in (Sambrook, Fritsch et al. 1989). After the transfer membrane was baked in $80^{\circ} \mathrm{C}$ oven for 2 hours, crosslinked in UV crosslinker (Bachofer laboratoriumsgeraete) $\left(0.3 \mathrm{~J} / \mathrm{cm}^{2}, 302 \mathrm{~nm}\right)$ and hybridized overnight at $65^{\circ} \mathrm{C}$ with ${ }^{32} \mathrm{P}-\alpha-\mathrm{dCTP}$ (Amersham) labeled probe in hybridization 


\section{Material and Methods}

solution $\left(0.5 \mathrm{M} \mathrm{Na}_{2} \mathrm{HPO}_{4}, \mathrm{pH} 7.2,7 \%\right.$ SDS). The membrane was after hybridization washed 3 times 20 min. in washing solution (40mM Na $2 \mathrm{HPO}_{4}, \mathrm{pH} 7.2,1 \%$ SDS) densitometricaly quantified by Instant Imager (Packard Instruments, Meridian, CT) and exposed to X-ray film (Biomax, Kodak) at $-70^{\circ} \mathrm{C}$ with intensifying screen.

\subsubsection{Northern blotting}

Total RNA was isolated from mouse cerebellum using Trizol Reagent (Gibco BRL) according to the protocol provided by the producer. 10-15 $\mu \mathrm{g}$ of total RNA was denatured in loading buffer (1.6 mM EDTA, $0.032 \%$ saturated bromphenol blue solution, $0.53 \%$ formaldehyde, $4 \%$ glycerol, $6.2 \%$ formamide, $16 \mathrm{mM}$ 3-[morpholino]propanesulfonic acid (MOPS), $4 \mathrm{mM}$ sodium acetate, $\mathrm{pH}$ 7.0) $5 \mathrm{~min}$. at $65^{\circ} \mathrm{C}$, chilled on ice and loaded on denaturing gel (1.2\% agarose, $20 \mathrm{mM}$ MOPS, $5 \mathrm{mM}$ sodium acetate, $1 \mathrm{mM}$ EDTA, $0.6 \%$ formaldehyde, $\mathrm{pH}$ 7.0). The gel was preincubated for minimum half an hour and subsequently run in running buffer (20 mM MOPS, $5 \mathrm{mM}$ sodium acetate, $1 \mathrm{mM}$ EDTA, 0.7\% formaldehyde, $\mathrm{pH}$ 7.0) 5-7 V per $\mathrm{cm}$. The gel was after electrophoresis stained with ethidium bromide in $0.5 \mu \mathrm{g} / \mathrm{ml}$ solution and transfered on nylon membrane (Quiagen) with 20x SSC as described in Sambrook et al. The membrane was then baked for 1 hour at $80^{\circ} \mathrm{C}$ oven and crosslinked in UV crosslinker (Bachofer laboratoriumsgeraete) $\left(0.3 \mathrm{~J} / \mathrm{cm}^{2}, 302 \mathrm{~nm}\right)$. Hybridization and probe synthesis was performed in the same way as described in the chapter.5.3.3.

\subsubsection{Screening of E15.5 mouse cDNA library}

\section{a) Bacterial culture plating}

C600 Hfl E.coli strain was streaked from the $25 \%$ glycerol stock onto a $\mathrm{MgSO}_{4}$-free LB agar plate and incubated overnight at $37^{\circ} \mathrm{C}$. Single colony was picked, inoculated into culture media (LB broth; $10 \mathrm{mM} \mathrm{MgSO}$; $0.2 \%$ maltose) and incubated on a shaker (200 rpm) at $37^{\circ} \mathrm{C}$ overnight until the $\mathrm{OD}_{600}$ of the culture reaches 2.0 


\section{Material and Methods}

\section{b) Titration of the phage library}

The phage lysate was diluted in ratio 1:250,000 in Lambda dilution buffer (LDB) and in separate tubes $0,2,5$ and $10 \mu \mathrm{l}$ of the diluted lysate was added to a mixture of $100 \mu \mathrm{LDB}$ and $200 \mu \mathrm{l}$ bacterial overnight culture. The mixture was incubated in $37^{\circ} \mathrm{C}$ water bath for 15 min, then $3 \mathrm{ml}$ of melted NZY soft top agar $\left(50^{\circ} \mathrm{C}\right)$ was added to each of the tubes, mixed well and poured on four separate $90-\mathrm{mm}$ NZY plates prewarmed at $37^{\circ} \mathrm{C}$. The plates were incubated at RT for $10 \mathrm{~min}$ and subsequently at $37^{\circ} \mathrm{C}$ at least 6-7 hours.

The titer in $\mathrm{pfu} / \mathrm{ml}$ was calculated from number of the plaques on the plates.

\section{c) Screening}

200,000 pfu were incubated for $15 \mathrm{~min}$ at $37^{\circ} \mathrm{C}$ with $3 \mathrm{ml}$ of bacterial overnight culture and $30 \mathrm{ml}$ soft top agar and plated on 243 x $243 \mathrm{~mm}$ NZY plates. In total 1 x $10^{6} \mathrm{pfu}$ were plated and incubated overnight at $37^{\circ} \mathrm{C}$. The next day 2 replicas of each plate were taken with nylon membranes (Quiagen) and marked with ink both on the membranes and plates.

The membranes were incubated for $2 \mathrm{~min}$ on filter papers soaked with denaturation solution and $5 \mathrm{~min}$ in neutralization solution. After a brief incubation $(30 \mathrm{~s})$ in $0.2 \mathrm{M}$ Tris / $\mathrm{HCl} \mathrm{pH} 7.5 ; 2 \mathrm{xSSC}$ solution the membranes were baked in the oven at $80^{\circ} \mathrm{C}$ for ca 2 hours and crosslinked in the UV-crosslinker $(0.3 \mathrm{~J} / \mathrm{cm} 2,302 \mathrm{~nm})$.

Membranes were then hybridized with $[\alpha]^{32} \mathrm{P}$ labeled DNA probe in the same way as described in the chapter "southern blotting".

\section{d) Isolation of the recombinant phage clones}

The autoradiograms of hybridized nylon membranes were marked with the same pattern as the nylon membranes aligned with the original NZY plates and area where a positive signal was detected was picked up with a cut pipette tip. The pieces of NZY agar with phage clones were incubated on a shaker overnight at $4^{\circ} \mathrm{C}$ in $1 \mathrm{ml} \mathrm{SM}$ buffer with $20 \mu \mathrm{l}$ of chlorophorm so that the phages could be released into the medium. 


\section{Material and Methods}

Secondary and sometimes tertiary re-screenings were necessary to perform so that single phage plaques could be isolated.

\section{e) Preparation of the high titer (HT) phage stocks}

The high titer phage stock was prepared from $4 \mathrm{ml}$ of SM media/50ml chlorophorm poured on a $100 \mathrm{~mm}$ NZY plate with fully lysed bacteria and incubated overnight on a shaker at $4^{\circ} \mathrm{C}$. The stock was stored at $4^{\circ} \mathrm{C}$.

\section{f) Isolation of the phage DNA}

$50 \mu \mathrm{l}$ of the overnight bacterial culture were infected with $1 \mu \mathrm{l}$ of the HT phage stock as described above and incubated in $20 \mathrm{ml} \mathrm{NZY} \mathrm{media} \mathrm{with} 0.2 \%$ maltose and $10 \mathrm{mM}$ magnesium sulfate at $37^{\circ} \mathrm{C}$ with permanent shaking $(250 \mathrm{rpm})$ until lysis of the bacteria was achieved (6-7 hours).

$8.5 \mu l \mathrm{RNase}(10 \mu \mathrm{g} / \mu \mathrm{l})$ und $8.5 \mu \mathrm{l}$ DNaseI $(10 \mu \mathrm{g} / \mu \mathrm{l})$ was added to the lysate and incubated at RT for $30 \mathrm{~min}$ on shaker. The bacterial pellet was removed by centrifugation for $20 \mathrm{~min}$ at $12000 \mathrm{rpm}$ (SA600 Rotor). $5 \mathrm{M} \mathrm{NaCl}$ (1/4 of the volume) was added to the supernatant and again spun down. 1/3 of the total volume of 40\% PEG (6000) was added to the supernatant and incubated on ice for 1 hour.

The phage particles were spun down at $10000 \mathrm{rpm}$ for $15 \mathrm{~min}$. The pellet was resuspended in $700 \mu \mathrm{l}$ of phage lyses buffer and incubated at $50^{\circ} \mathrm{C}$ for $45 \mathrm{~min}$. The phage DNA was isolated through phenol/chlorophorm/isoamylalcohol extraction $(2 \mathrm{x} 700 \mu \mathrm{l})$ precipitated by 5 minutes incubation with $800 \mu \mathrm{l}$ isopropanol/0,8M ammoniumacetate on ice, spun

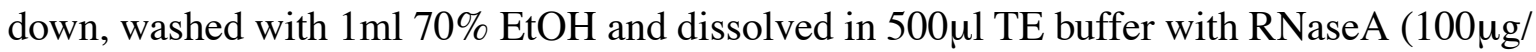
$\mathrm{ml}$ ) and incubated for $30 \mathrm{~min}$ at $37^{\circ} \mathrm{C}$. After the RnaseA treatment, the DNA was again extracted with phenol/chlorophorm/isoamylalcohol, precipitated with isopropanol and dissolved in $50 \mu \mathrm{l} \mathrm{T}_{10} \mathrm{E}_{0.1}$ buffer.

$5 \mu l$ of the DNA was digested with an appropriate restriction endonuclease. The inserts were cloned into pBSII KS+ vector. 


\section{Material and Methods}

\subsubsection{Genotyping of the animals}

For genotyping of the animals both Southern blotting and PCR methods were used.

\section{a) Southern blotting}

Southern blotting was performed as described in the chapter 5.3.3. For genotyping of the animals quantitative Southern blotting was used to measure relative number of Gene Trap vector copies per genome. Intensity of the signal obtained after hybridization with Gene Trap probe (lacZ) was measured on Instant imager and compared to intensity of signal obtained after hybridization with an internal control probe ( $F k h 5$ gene probe (Wehr, Mansouri et al. 1997)). Lac Z probe was made after AvaI digestion of plasmid pCH110 and isolation of $1443 \mathrm{bp}$ fragment containing lac $Z$ sequence from gel.

\section{b) PCR}

PCR genotyping method was based on known chromosomal localization of Trim2 gene on mouse chromosome 3, area E3 and Simple sequence length polymorphism markers (SSLP) obtained from Whitehead Insitute homepage (http://www-genome.wi.mit.edu/). Several markers that are localized within $0.1 \mathrm{cM}$ distance from Trim 2 locus were tested for PCR polymorphism between mouse strains C57/B16 and 129SV. For further genotyping primers D3Mit97L (ACTGCATATGTATGTGTGCATG) and D3Mit97R (AGAACATGAAATAACCATGAAAAGC) were selected. PCR products (107 bp C57/B16 and $101 \mathrm{bp}$ $129 \mathrm{SV})$ were separated on $6 \%$ agarose gel electrophoresis.

PCR conditions used: denaturation: $94^{\circ} \mathrm{C} 45 \mathrm{sec}$.

annealing: $60^{\circ} \mathrm{C} 45 \mathrm{sec}$.

polymerization: $72^{\circ} \mathrm{C} 45 \mathrm{sec}$.

number of cycles:30

\subsubsection{Western blotting}

Proteins dissolved in the sample buffer were loaded on the polyacrylamid gel composed of stucking and resolving gels and separated under constant voltage of $2.5-5 \mathrm{~V} / \mathrm{cm}$. 


\section{Material and Methods}

Stucking gel:

$0.125 \mathrm{M}$ Tris- $\mathrm{HCl} \mathrm{pH} 6.8$

$0.1 \%$ SDS

$0.1 \%$ APS

$0.1 \%$ TEMED

$3.2 \%$ acrylamide
Resolving gel:

$0.375 \mathrm{M}$ Tris- $\mathrm{HCl} \mathrm{pH} 8.8$

$0.1 \%$ SDS

$0.05 \%$ APS

$0.05 \%$ TEMED

$8-11 \%$ acrylamide

The separated proteins were transferred by electroblotting on a nylon membrane (Immobilon-P, Millipore) in a Transfer buffer under a constant current $3.5 \mathrm{~mA} / \mathrm{cm}^{2}$ for 80 $\min$.

The membrane was subsequently stained in Ponceau S solution for 4 min. to visualize the transferred proteins and destained in destaining solution for $5 \mathrm{~min}$. with several changes of the solution.

The membrane was incubated at the room temperature on shaker in blocking solution for 1 hour to reduce unspecific binding of antibodies and then in $4{ }^{\circ} \mathrm{C}$ overnight with antibodies diluted in blocking solution. The unbound antibodies were washed out $10 \mathrm{~min}$. in washing solutions A, B and A sequentially. After the washes membrane was incubated with secondary antibodies-HRP (horseradish peroxidase) conjugate diluted in blocking solution for 1 hour at the room temperature. The unbound secondary antibodies were washed out in the same way as primary antibodies. Proteins were detected with SuperSignal chemiluminescent substrate (Pirce) according to the producer's instructions.

$\begin{array}{ll}\text { Wash buffer A: } & \text { Wash buffer B: } \\ 10 \mathrm{mM} \text { Tris-Cl pH 7.5 } & 0.2 \% \mathrm{SDS} \\ 0.9 \% \mathrm{NaCl} & 0.9 \% \mathrm{NaCl} \\ 0.05 \% \text { Tween-20 } & 0.5 \% \text { Triton X-100 }\end{array}$




\section{Material and Methods}

\section{Blocking solution:}

$5 \%$ skimmed milk powder in Wash buffer A

\section{Dilution of antibodies:}

Goat-anti-rabbit-HRP (dianova) 1:5-10000

Goat-anti-mouse-HRP (dianova) 1:5-10000

\subsubsection{Pull-down assay}

Cells were washed once in PBS and harvested. Spun down 2000 rpm (Heraeus, biofuge pico), supernatant discarded and cells were lysed in $200 \mu \mathrm{l}$ of lysis buffer (150 mM $\mathrm{NaCl}, 50 \mathrm{mM}$ Tris $\mathrm{HCl} \mathrm{pH} 7.5,0.5 \%$ NP-40, protease inhibitors-Roche). Following the lysis cell debris was spun down $13000 \mathrm{rpm} 10 \mathrm{~min}$. (Heraeus, biofuge pico) at $4^{\circ} \mathrm{C}$ and the supernatant was incubated in shaker overnight with c-myc beads (Santa Cruz) at $4^{\circ} \mathrm{C}$. The beads were after the incubation spun down $2500 \mathrm{rpm}$ (Heraeus, biofuge pico) and supernatant discarded. The pellet was resuspended $1 \mathrm{ml}$ of lysis buffer and incubated on shaker for 15 min at $4^{\circ} \mathrm{C}$. The beads were spun down as described above and the whole washing was repeated 4 times. Following the last wash the beads were dissolved in Protein sample buffer (see western blotting) and used for SDS polyacrylamid gel electrophoresis.

\subsubsection{Coomassie Blue staining}

After the proteins were separated on a polyacrylamide gel electrophoresis (PAGE) the entire gel was submerge in the Coomassie Blue staining solution and stained for minimum 30 minutes but not more then 3 hours with a gentle agitation at room temperature. After the staining the excess of the dye was removed by washing in several changes of Coomassie Blue destaining solution I (for ca $2-3$ hours). When most of the background stain was removed the gel was transferred to the Coomassie Blue destaining solution II and washed with a gentle agitation. A few Kim-Wipe papers were put into the destaining solution to absorb the released dye from the solution. 


\section{Material and Methods}

\subsubsection{Silver staining}

(At least a 10fold of the gel volume is required for all solutions)

A polyacrylamide gel was fixed in fixative solution for a long time, preferably overnight. The gel can be kept in this solution for several days. (If mass spec. analysis of stained bands was to be performed, fixation time was max. 2 hours!).

The fixed gel was washed 2 times in 50\% ethanol for 20 minutes each wash. This step removes the traces of acetic acid to avoid decomposition of thiosulfate and subsequent $\mathrm{AgS}_{2}$ formation.

Following the two washes the gel was incubated exactly 60 seconds with $0.8 \mathrm{mM}$ $\mathrm{Na}_{2} \mathrm{~S}_{2} \mathrm{O}_{3}$. Only traces of thiosulfate should be present in the gel.

The gel was washed 3 times $20 \mathrm{sec}$ with water to remove thiosulfate from the gel.

After the washes the gel was impregnated for 20 minutes with impregnation solution. The gel may then appear yellowish due to thiosulfate impregnation. This has no adverse effect.

The gel was washed again 3 times $20 \mathrm{sec}$ with water.

The development was done in the developing solution usually for 2 to $10 \mathrm{~min}$. A faint precipitate on the gel surface was - if present - dissolved by vigorous shaking. (Prolonged developing times reduce the yield of peptides extracted from the gel pieces for mass spec analysis!)

The developing was stopped by incubation in fixative solution.

(All solutions must be prepared freshly, except for the silver stock solution (1M) which can be stored in a brown bottle in the fridge $\left(4^{\circ} \mathrm{C}\right)$ over month)

\subsubsection{Fluorescence in situ hybridization (FISH)}

Localization of Trim 2 on mouse chromosome was performed by "SeeDNA" company (Ontario). The whole biotin-labeled cDNA of Trim2 was used as a probe. Assignment of 


\section{Material and Methods}

the FISH mapping data with chromosomal bands was achieved by superimposing FISH signals with DAPI banded chromosomes

\subsection{Histology techniques}

\subsubsection{Brain perfusion}

Mice anesthetized with avertin were perfused intracardialy using a peristaltic pump ( $5 \mathrm{ml} / \mathrm{min}$.) first with PBS (2-5 min.) and subsequently for $10 \mathrm{~min}$. with ice-cold fixative solution. Brains were quickly removed and postfixed for additional 4 hours in fixative solution. Fixed brains were washed in $0.1 \mathrm{M}$ phosphate buffer, embedded in paraplast or cryomatrix or cut directly in vibratom.

\subsubsection{Embedding and sectioning of the fixed tissues}

\section{a) in paraplast}

Postfixed tissues were washed in PBS buffer on ice for 4 hours and subsequently dehydrated in increasing ethanol concentrations $(50 \%, 70 \%, 90 \%, 100 \%, 100 \%) 24$ hours each dilution on shaker. Tissues were inccubated in Histoclear (Xylene substitution) for $2 \mathrm{x}$ 24 hours and afterwards in three changes of $60{ }^{\circ} \mathrm{C}$ Paraplast (24 hours each). The tissues were then embedded in the correct orientation in paraplast.

The embedded tissues were cut in microtome (Reichert-Jung, Biocut, 2035, Leica) in 10 - $15 \mu \mathrm{m}$ thick sections, flattened on water surface of ca. $40^{\circ} \mathrm{C}$ warm watter bath and collected on gelatine treated glass slides . The sections were dried out overnight at $37^{\circ} \mathrm{C}$.

\section{b) in cryomatrix}

Postfixed tissues were washed in phosphate buffer on ice for minimum of 4 hours (to overnight) and incubated on ice overnight in $25 \%$ sucrose solution in phosphate buffer. The tissues were subsequently immersed, washed and embedded in Cryomatrix on dry ice. 


\section{Material and Methods}

\subsection{3 $\beta$-gal staining}

a) of the whole embryos

Embryos of the defined developmental stage were isolated, washed in PBS on ice and fixed in fixative solution ( $1 \%$ formaldehyde, $0.2 \%$ glutaraldehyde, $0.02 \%$ nonidet P-40 in PBS) according to their age (day 9.5 and 10,5 p.c. 30 min., day 11.5 p.c. 40 min., day 12.5 p.c. 50 min.) Fixed embryos were washed $2 \times 20 \mathrm{~min}$. in PBS at RT and stained overnight at $30^{\circ} \mathrm{C}$ in $\mathrm{X}-\mathrm{Gal}$ staining solution $\left(1 \mathrm{mg} / \mathrm{ml} \mathrm{X-Gal,} 2 \mathrm{mM} \mathrm{K}_{3} \mathrm{Fe}(\mathrm{CN})_{6}, 2 \mathrm{mM} \mathrm{K}_{4} \mathrm{Fe}(\mathrm{CN})_{6}, 2\right.$ $\mathrm{mM} \mathrm{MgCl} 2$ in PBS). The staining was stopped by $2 \mathrm{x} 20 \mathrm{~min}$. washes in PBS. Subsequently the embryos were cleared by soaking sequentially in $15 \%, 30 \%, 50 \%, 70 \%, 80 \%$ glycerol in PBS ( 30 min. each step)

\section{b) of the adult brains}

Adult mice were anesthetized and perfused as described in before with fixative solution containing $1 \%$ formaldehyde, $0.2 \%$ glutaraldehyde, $0.02 \%$ nonidet P-40 and $0.1 \%$ sodium deoxycholate in PBS. Perfused brains were isolated and postfixed on ice for 3 hours in the same fixative solution. Fixation was stopped by 3x 20 min. washes in PBS on ice. Fixed brains were cut in vibratom in $300 \mu \mathrm{m}$ sections and stained in X-Gal staining solution as described above. Stained sections were either directly used for imaging or dehydrated in ethanol (50\%, 70\%, 90\%, 100\%, 100\%; 30 min. each) immersed in Histoclear (2x 20 min.) and embedded in paraplast $\left(2 \mathrm{x} 4\right.$ hours, $\left.60^{\circ} \mathrm{C}\right)$ for further recutting in microtom.

\subsubsection{Immunohistochemistry}

a) on paraffin sections

Sections were first incubated 2 times $10 \mathrm{~min}$ in Histoclear to dissolve paraplast and then rehydrated in series of ethanol/ $\mathrm{H}_{2} \mathrm{O}$ dilutions (100\% ethnol 2x $10 \mathrm{~min}$., $90 \%, 70 \%$, 50\% each 2 min.) and washed in PBS 2 times $3 \mathrm{~min}$. Slides were then boiled 2 times $3 \mathrm{~min}$. in unmasking solution (Vector) to expose the epitopes for antibodies and incubated for 15 min in $3 \%$ hydrogen peroxide/PBS solution to inactivate endogenous peroxidase. Subse- 


\section{Material and Methods}

quently the sections were washed 2 times 2 min. in $0.1 \%$ Tween-20 in PBS (PBT) and blocked for 1 hour in blocking solution (10\% FCS in PBT). The sections were after the blocking incubated overnight at $4{ }^{\circ} \mathrm{C}$ with antibodies in blocking sloution.

Following the incubation with antibodies the sections were washed 2 times $2 \mathrm{~min}$. in PBT and incubated for 1 hour with secondary antibodies (ABC universal kit, Vector). After the incubation the sections were again washed 2 times $2 \mathrm{~min}$. in PBT and incubated for another 1 hour with $\mathrm{BC}$ reagent (ABC universal kit, Vector). Sections were washed in PBT $2 \times 2 \mathrm{~min}$. and stained with staining solution ( $0.3 \%$ hydrogen peroxide, $0.3 \mathrm{M}$ diaminobenzidin in PBS) for 2 to $6 \mathrm{~min}$. After staining the sections were dehydrated in rising ethanol concentrations $(50 \%, 70 \%, 90 \%, 100 \%, 100 \%$ each 2 min.), immersed in Histoclear 2 times 5 min. and mounted in Eukit.

When fluorescently labeled secondary antibodies were used, the sections were after final washes directly mounted in moviol with $1 \mu \mathrm{g} / \mathrm{ml}$ Hoechst33258. Staining was detected with fluorescent (Olympus) or confocal (Leica) microscop.

\section{b) on cryostat sections}

Frozen sections were thawed and washed for 5 - 10 min in PBS buffer. After washing the sections were either boiled for 4 minutes in unmasking solution (Vector), let to chill down to room temperature (to enhance exposure of the antigens) and incubated for $1-2$ hours in blocking solution (5-10\% FCS, 0.2\% TritonX100 in PBS), or directly incubated with the blocking solution (when no unmasking of the antigens was needed). Blocked sections were incubated overnight at $4^{\circ} \mathrm{C}$ with primary antibodies, washed twice 3 minutes in PBS-T (0.2\% TritonX100) and incubated with secondary antibodies (Vectastain ABC kit or fluorescently labeled). Detection of bound antibodies was done, after additional two washes in PBS-T, in the same way as described in the previous chapter. 


\section{Material and Methods}

\subsubsection{Nissl staining}

Sections were dehydrated in the same way as described in chapter 5.4.2, washed in deionized $\mathrm{H}_{2} \mathrm{O}$ for 2 min. and incubated for $15 \mathrm{~min}$. in $50 \%$ (w/v) potassium sulfit solution. Sections were washed 2 times $1 \mathrm{~min}$ in $\mathrm{H}_{2} \mathrm{O}$ and stained for $20 \mathrm{~min}$. in cresylviolett solution (1.5\% cresylviolett, $10 \mathrm{mM}$ sodium acetate, $10 \mathrm{mM}$ acetic acid in $\mathrm{H}_{2} \mathrm{O}$ ). Following the staining sections were washed 2 times $2 \mathrm{~min}$. in acetate buffer $(10 \mathrm{mM}$ sodium acetate, 10 $\mathrm{mM}$ acetic acid in $\mathrm{H}_{2} \mathrm{O}$ ), rinsed in $\mathrm{H}_{2} \mathrm{O}$ and dehydrated in series of ethanol/ $\mathrm{H}_{2} \mathrm{O}$ dilutions (70\%, 100\%, 100\% each 2 min.). After dehydration the sections were immersed for $10 \mathrm{~min}$. in Histoclear and mounted in Eukitt (E.Kindler GmbH).

\subsubsection{Nonradioactive in situ hybridization}

\section{a) Synthesis of digoxigenin labeled Ribo-probe}

The ribo-probes were in-vitro transcribed from DNA fragments cloned into pBluescriptII KS+ (pBS-TRIM2-1.1) or pGEM T easy (pGEM-TRIM2-0.6) vectors. The vectors were first linearized by restriction digestion by SacI (pGEM-TRIM2-0.6 sense), SacII (pGEM-TRIM2-0.6 antisense), EcoRI (pBS-TRIM2-1.1 antisense) or HindIII (pBSTRIM2-1.1 sense), separated by agarose gel electrophoresis and linearized fragments purified by isolation from gel.

The transciption was performed in RNA transcription buffer in the presence of RNase inhibitors for 2 hours at $37^{\circ} \mathrm{C}$. For transcription of $1 \mu \mathrm{g}$ of purified plasmid DNA following RNA polymerases were used:

pBS-TRIM2-1.1 sense probe: T7 RNA polymerase

pBS-TRIM2-1.1 antisense probe:T3 RNA polymerase

pGEM-TRIM2-0.6 sense probe:T7 RNA polymerase

pGEM-TRIM2-0.6 antisense probe:SP6 RNA polymerase 


\section{Material and Methods}

After the 2 hours of transcription the DNA template was digested with RNase free DNase I $(0.1 \mathrm{U} / \mu \mathrm{l})$ for $15 \mathrm{~min}$ at $37^{\circ} \mathrm{C}$ and precipitated by adding $4 \mathrm{M} \mathrm{LiCl}(1 / 10$ of the original volume) and ethanol (2.5x original volume). Precipitated RNA was dissolved in 50 $\mu$ l of DEPC treated water and kept at $-70^{\circ} \mathrm{C}$. Quality and amount of the transcribed probe was examined by electrophoresis in agarose gel.

\section{b) Hybridization}

The brains embedded in cryomatrix were cut in cryostat in $15 \mathrm{~mm}$ sections and kept at $-20^{\circ} \mathrm{C}$. The non-radioactive in-situ hybridization procedure was performed in three days. All the solutions used in the day 1 and 2 before application of the blocking solution were made with DEPC treated $\mathrm{H}_{2} \mathrm{O}$ :

\section{Day 1:}

The sections on slides were brought to room temperature, fixed in 4\% PFA for 15 minutes at room temperature and washed twice 5 minutes in PBS buffer. After the second wash sections were treated with $20 \mu \mathrm{g} / \mathrm{ml}$ proteinase $\mathrm{K}$ solution at $37^{\circ} \mathrm{C}$ for 5 minutes followed by 5 minutes wash in $0.2 \%$ glycin/PBS buffer and twice 5 minutes in PBS buffer. The sections were fixed in $4 \%$ faraformaldehyde $+0.2 \%$ glutaraldehyde solution in PBS and again washed twice 5 minutes in PBS.

Subsequently borders were drown around the sections with the ImmEdge pen (Vector) and sections were pre-hybridized with hybridization buffer in a humidified chamber at $70^{\circ} \mathrm{C}$ for 2 hours.

The hybridization with DIG-labeled probe diluted in hybridization buffer was performed overnight at $70^{\circ} \mathrm{C}$ in humidified chamber.

\section{Day 2:}

The sections were rinsed in $2 \mathrm{xSSC}, \mathrm{pH} 4.5$ buffer and washed three times 30 minutes at $65^{\circ} \mathrm{C}$ in washing solution (50\% formamide/2x SSC, $\mathrm{pH} 4.5$ ) and twice 10 minutes in KTBT buffer. Subsequently the slides were incubated in blocking solution (20\% sheep 


\section{Material and Methods}

serum in KTBT) for 2 hours at room temperature and afterwards overnight at $4{ }^{\circ} \mathrm{C}$ in working dilution of anti-DIG alkaline phosphatase conjugate antibodies (1:2000 in blocking solution).

\section{Day 3:}

The antibodies were washed out in six changes of KTBT buffer ( $3 \times 5$ min. and $3 \times 30$ min.). After the washes sections were incubated 3 times 5 minutes in NTMT buffer and finally the color reaction was performed at room temperature in the dark humid box for usually 2-5 hours. The reaction was stopped in three washes of PBS-T buffer, fixed in 4\% PFA in PBS (10 minutes, room temperature), rinsed in PBS and mounted in Mowiol.

\subsubsection{Radioactive in situ hybridization}

a) Synthesis of radioactively labeled Ribo-probe

$[\alpha] 35$ S-UTP labeled RNA-probes were used for the radioactive in situ-hybridization on paraffin sections. The transcription mix (see buffers) was prepared and incubated at $37^{\circ} \mathrm{C}$ for $1 \mathrm{~h}$. The template DNA used for the RNA transcription was linearized in the same way and the same RNA polymerases were used as described in the previous chapter.

After transcription the DNA template was digested by incubation with $1 \mathrm{ml}$ yeast total RNA $(10 \mathrm{mg} / \mathrm{ml})$ and $3 \mu \mathrm{l} \mathrm{RNase}$ free DNase $\left(20 \mathrm{u} / \mu \mathrm{l}\right.$, Promega) for $10 \mathrm{~min}$ at $37{ }^{\circ} \mathrm{C}$. The probe was purified with ProbeQuantTMG-50 microcolumn (Pharmacia) and diluted to $100 \mathrm{ml}$ with water and supplied with $25 \mu \mathrm{l}$ formamide and $2,5 \mu 1 \mathrm{M}$ DTT. $1 \mu \mathrm{l}$ of the probe was diluted in $5 \mathrm{ml}$ of scintillation solution and incorporation efficiency was measured with a Scintillation counter (Beckman LS 1701).

\section{b) Treatment of the sections}

The microtome sections were first de-paraffinized and hydrated with series of xylol and ethanol washes, treated with proteinase $\mathrm{K}$ and acetylation mix and again dehydrated:

Xylol $10 \min$ 


\title{
Material and Methods
}

\author{
Xylol 10 min \\ $100 \%$ EtOH 5 min \\ $100 \%$ EtOH 5 min \\ 90\% EtOH 2 min \\ $70 \%$ EtOH 2 min \\ $50 \%$ EtOH 2 min \\ Saline $(0,86 \% \mathrm{w} / \mathrm{v} \mathrm{NaCl}) 5 \mathrm{~min}$ \\ PFA/PBS $20 \mathrm{~min}$ \\ PBS 2 min \\ PBS 2 min \\ Proteinase K (working dilution) $7 \mathrm{~min}$ \\ PBS 5 min \\ Acetylation Mix 10 min \\ PBS 5 min \\ Saline $(0,86 \% \mathrm{w} / \mathrm{v} \mathrm{NaCl}) 5 \mathrm{~min}$ \\ $30 \% \mathrm{EtOH} 2 \mathrm{~min}$ \\ $50 \%$ EtOH 2 min \\ $70 \%$ EtOH 2 min \\ $80 \%$ EtOH 2 min \\ $90 \%$ EtOH 2 min \\ 95\% EtOH 2 min \\ $100 \%$ EtOH 2 min
}

After the dehydration the sections were let at room temperature for 1 hour to dry out completely.

The RNA-probe was diluted with hybridization buffer to a final concentration

$5 \times 104 \mathrm{cpm} / \mu \mathrm{l}$. Before application the diluted probe was heated for 2 minutes at $80^{\circ} \mathrm{C}$ and approximately $4 \mu \mathrm{l}$ of probe were put on every section and carefully covered with a glass coverslip $(15 \times 20 \mathrm{~mm})$.

The hybridization was done overnight at $50^{\circ} \mathrm{C}$ in a sealed box humidified with filter paper soaked in solution of $50 \%$ Formamide and $2 x S S C$

c) Washes

The slides were after the hybridization washed in a mixture of $5 \mathrm{x} \mathrm{SSC,} \mathrm{50 \%} \mathrm{(v/v)} \mathrm{for-}$ mamide, $0.14 \%(\mathrm{v} / \mathrm{v}) \beta$-mercaptoethanol at $50^{\circ} \mathrm{C}$ for $20 \mathrm{~min}$. The second wash was done at $60{ }^{\circ} \mathrm{C}$ for $20 \mathrm{~min}$ in $2 \mathrm{xSSC}, 50 \%(\mathrm{v} / \mathrm{v})$ formamide, $0.14 \%(\mathrm{v} / \mathrm{v}) \beta$-mercaptoethanol solution 


\section{Material and Methods}

with a gentle agitation. The coverslips fall off during the previous wash steps and sections were washed twice 5 minutes at $37^{\circ} \mathrm{C}$ in NTE buffer and then for additional 30 minutes in NTE buffer supplied with RNase A (final concentration $20 \mu \mathrm{g} / \mathrm{ml}$ ) for 30 minutes. The RNase A was again washed out in NTE- buffer for 30 minutes.

Finally the sections were washed for 20 minutes at $60^{\circ} \mathrm{C}$ in $2 \mathrm{xSSC}, 50 \%(\mathrm{v} / \mathrm{v})$ formamide, $0.14 \%(\mathrm{v} / \mathrm{v}) \beta$-Mercaptoethanol; for 30 minutes at $60{ }^{\circ} \mathrm{C}$ in $2 \mathrm{xSSC}$ and for $30 \mathrm{~min}$ at $60{ }^{\circ} \mathrm{C}$ in $0,1 \mathrm{xSSC}$.

During the washing steps the unspecifically bound probe was released due to the high temperature and decreasing salt concentration so that only the specific RNA-RNA hybrids remained on the section.

Following the washing steps the sections were dehydrated in series of ethanol washes $(30 \%, 50 \%, 70 \%, 80 \%, 90 \%, 95 \%, 100 \%)$ and exposed overnight with Biomax film (Kodak) to estimate the strength and specificity of the obtained signal.

\section{d) Exposure, development and staining}

The slides were in total darkness dipped in $10 \mathrm{ml}$ solution of Kodak NTB-2 liquid emulsion + water $(1: 1)$ in dipping chamber warmed up to $42^{\circ} \mathrm{C}$, dried and put into a lighttight plastic box wrapped around with aluminum foil. The box was then kept at $4{ }^{\circ} \mathrm{C}$ in the dark for 7-12 days (usually 10).

After the exposition, the emulsion was developed again in absolute darkness by dipping in $16 \%(\mathrm{w} / \mathrm{v})$ Kodak D-19 developer solution for 3 minutes at $18^{\circ} \mathrm{C}$, washed in $1 \%(\mathrm{v} /$ v) acetic acid solution for 1 minute and fixed in $30 \%(w / v)$ natriumthiosulfate solution for 3 minutes. Finally the slides were washed several times with water and stained with Giemsa solution for 30 minutes to visualize the cell and tissue structures of the sections. The excess of the stain was washed out with tap water, sections were dried out on the air and mounted in Eukitt mounting reagent.

The bright and dark field images of the sections were taken with Zeiss Axiophot and Olympus BX60 microscopes. 


\section{Material and Methods}

\subsubsection{TUNEL assay}

Microtome sections were deparaffinized in 3 changes of xylene for $5 \mathrm{~min}$. each, and hydrated in series of ethanol washes $(100 \%, 100 \%, 95 \%, 70 \%) 3$ min. each. Finally sections were immersed in PBS for $5 \mathrm{~min}$. Sections were subsequently treated with $20 \mathrm{mg} / \mathrm{ml}$ Proteinase $\mathrm{K}$ in PBS buffer at room temperature for 15 minutes and washed two times two minutes in PBS. Sections were subsequently incubated in equilibration buffer (supplyed by producer - Intergen) for at least 10 seconds at room temperature and afterwards in humidified chamber at $37^{\circ} \mathrm{C}$ with TdT (terminal deoxynucleotidyl transferase) enzyme diluted in equilibration buffer containing digoxin-labeled nucleotides (Intergen) for 1 hour. The reaction was stopped by 10 minutes washing in stop buffer (Intergen) and afterwards anti-digoxigenin-fluorescein conjugate (Intergen) was applied on the sections and incubated for 30 min. at room temperature. Slides were washed 4 times $2 \mathrm{~min}$. in PBS and mounted in mowiol with $1 \mu \mathrm{g} / \mathrm{ml}$ Hoechst33258 for nuclear counterstaining.

\subsubsection{Fluoro-jade B staining}

Brain cryostat sections ( $20 \mu \mathrm{m}$ thick) were incubated in $0.1 \mathrm{M}$ phosphate buffer for 3 min. and dried for at least $30 \mathrm{~min}$. at $50^{\circ} \mathrm{C}$. After dehydration the slides were first immersed in a solution containing $1 \%$ sodium hydroxide in $80 \%$ alcohol for 5 minutes followed by two minutes incubation in $70 \%$ alcohol and 2 minutes in distilled water. The slides were transferred to a solution of $0.06 \%$ potassium permaganate and incubated on shaker for 10 min., rinsed in distilled water for $2 \mathrm{~min}$ and stained for $20 \mathrm{~min}$. in $0.0004 \%$ solution of Fluoro-Jade B (Histo-Chem Inc.) in $0.1 \%$ acetic acid. Slides were counterstained in $1 \mu \mathrm{g} / \mathrm{ml}$ Hoechst 33258 (Sigma) solution, rinsed three times 1 minute in distilled water and dried on slide warmer at $50^{\circ} \mathrm{C}$ until they were fully dry. The slides were cleared in xylene for at least a minute and coverslipped with DPX mounting medium (Electron Microscopy Sciences). 


\section{Material and Methods}

\subsection{Cell culture techniques}

\subsubsection{Protein overexpression in Neruo2a (N2a) cell line}

DNA constructs used for transfection were purified by precipitation with 2.5 volumes of ethanol in presence of $3 \mathrm{M}$ sodium acetate $\mathrm{pH} 5.2$, washed in $70 \%$ ethanol and disolved in sterile water. For transfection, FuGENE 6 transfection reagent (Roche) was used according to the manufacturer's protocol. Neuro $2 \mathrm{~A}$ cells were plated with density $3 \times 10^{5}$ on a 6 well plate one day prior to transfection. $2.5 \mu \mathrm{g}$ of DNA was combined with $6 \mu \mathrm{l}$ of FuGENE 6 reagent in total volume of $100 \mu \mathrm{l}$ of serum free DMEM medium (Gibco BRL) and applyed on cells. Cells were harvested 1.5 days after transfection.

Mouse neuroblastoma cell line Neuro2A used for transfections was cultured in DMEM medium (Gibco BRL) with 10\% fetal calf serum (Gibco BRL), $100 \mathrm{U} / \mathrm{ml}$ Penicillin (Gibco BRL) and $100 \mu \mathrm{g} / \mathrm{ml}$ Streptomycin (Gibco BRL).

\subsubsection{Protein extraction from cultured N2a cells}

Cells grown to ca. $70 \%$ confluence on P85 plate were washed with $10 \mathrm{ml}$ PBS and harvested using a rubber scraper in another $10 \mathrm{ml}$ PBS. The cell suspension was spun down 1000 RPM for ca. 7 minutes (Hereaeus, Labofuge GL) and pellet re-suspended in $500 \mu l$ of lyses buffer $(150 \mathrm{mM} \mathrm{NaCl}, 50 \mathrm{mM}$ TrisCl $\mathrm{pH} 8 ; 0.5 \%$ TritonX100, protease inhibitors Roche). The suspension was run several times through $1 \mathrm{ml}$ pipette (pipetman) and incubated on a shaker at $4{ }^{\circ} \mathrm{C}$ for 30 minutes. Afterwards the lysate was pipetted again several times up and down through $1 \mathrm{ml}$ pipette and spun $20000 \mathrm{xg}$ at $4{ }^{\circ} \mathrm{C}$ for 30 minutes. The supernatant was collected, protein concentration was measured with bio-rad protein assay and used for pull-down assays or Western blotting.

\subsubsection{Immunostaining of cultured $\mathrm{N} 2 \mathrm{a}$ cells}

$\mathrm{N} 2 \mathrm{a}$ cells were cultivated in a $35 \mathrm{~mm}$ plates on a sterile coverslip to ca. $70 \%$ confluence. The coverslips were before incubated for at least 2 hours with $0.1 \mathrm{mg} / \mathrm{ml}$ Poly-L-lysine 


\section{Material and Methods}

solution to enable attachment of the cells to the glass surface, rinsed twice in sterile water and let dry in SterileGARD Hood (the Baker company, inc).

The cells were washed in PBS and fixed on the slide by incubating in 4\%PFA/PBS solution for $10 \mathrm{~min}$ at room temperature. After fixation the cells were washed 3 times $5 \mathrm{~min}$ utes in PBT solution and permeabilized in PBS with $0.1 \%$ TritonX100 for $10 \mathrm{~min}$. The coverslip with the cells was then put in a humidified box on a parafilm membrane with ca $50 \mathrm{ml}$ of blocking solution and blocked for $30 \mathrm{~min}$ at room temperature. The cells were then incubated in a similar way with primary antibodies diluted in blocking solution ( 2 hours at RT to overnight at $4^{\circ} \mathrm{C}$ ), washed twice 2 minutes in PBT, incubated with secondary fluorescent antibodies (1 hour RT), washed twice 2 minutes in PBT and mounted in mowiol.

If non-fluorescent secondary antibodies (Vectastain $\mathrm{ABC}$ kit) were to be used, the coverslip with permeabilized cells was before blocking incubated for 15 minutes at RT with $3 \%$ hydrogen peroxide solution in PBS to inactivate endogenous peroxidase, washed twice 2 min in PBT and blocked in the same way as described above. The color reaction was done in DAB staining solution ( $0.3 \%$ hydrogen peroxide, $0.3 \mathrm{M}$ diaminobenzidine in PBS) for 2 -5 minutes at RT. 


\section{References}

\subsection{References}

Aiba, A., M. Kano, et al. (1994). "Deficient cerebellar long-term depression and impaired motor learning in mGluR1 mutant mice.” Cell 79(2): 377-88.

Altman, J. and S. A. Bayer (1997). Development of the cerebellar system in Relation to its evolution, structure and functions.

Altschul, S. F., W. Gish, et al. (1990). "Basic local alignment search tool." J Mol Biol 215(3): 403-10.

Alves-Rodrigues, A., L. Gregori, et al. (1998). "Ubiquitin, cellular inclusions and their role in neurodegeneration." Trends Neurosci 21(12): 516-20.

Barton, R. M. and H. J. Worman (1999). "Prenylated prelamin A interacts with Narf, a novel nuclear protein.” J Biol Chem 274(42): 30008-18.

Bateman, A., E. Birney, et al. (2000). "The Pfam protein families database.” Nucleic Acids Res 28(1): 263-6.

Borden, K. L. and P. S. Freemont (1996). "The RING finger domain: a recent example of a sequence-structure family.” Curr Opin Struct Biol 6(3): 395-401. 


\section{References}

Brown, S. D. and J. Peters (1996). "Combining mutagenesis and genomics in the mouse-closing the phenotype gap." Trends Genet 12(11): 433-5.

Browne, D. L., S. T. Gancher, et al. (1994). "Episodic ataxia/myokymia syndrome is associated with point mutations in the human potassium channel gene, KCNA1." Nat Genet 8(2): $136-40$.

Campuzano, V., L. Montermini, et al. (1996). "Friedreich's ataxia: autosomal recessive disease caused by an intronic GAA triplet repeat expansion.” Science 271(5254): 1423-7.

Chang, B., N. L. Hawes, et al. (2002). "Retinal degeneration mutants in the mouse." Vision Res 42(4): 517-25.

Chong, S. S., A. E. McCall, et al. (1995). "Gametic and somatic tissue-specific heterogeneity of the expanded SCA1 CAG repeat in spinocerebellar ataxia type 1." Nat Genet 10(3): 344-50.

Cowan, W. M., J. W. Fawcett, et al. (1984). "Regressive events in neurogenesis." Science 225(4668): 1258-65.

Chowdhury, K., P. Bonaldo, et al. (1997). "Evidence for the stochastic integration of gene trap vectors into the mouse germline." Nucleic Acids Res 25(8): 1531-6.

Chung, K. K., V. L. Dawson, et al. (2001). "The role of the ubiquitin-proteasomal pathway in Parkinson's disease and other neurodegenerative disorders." Trends Neurosci 24(11 Suppl): S7-14.

Collins, F. S. (1995). "Positional cloning moves from perditional to traditional." Nat Genet 9(4): 347-50.

De Jager, P. L. and N. Heintz (1998). "The lurcher mutation and ionotropic glutamate receptors: contributions to programmed neuronal death in vivo." Brain Pathol 8(4): 795-807.

De Zeeuw, C. I., J. I. Simpson, et al. (1998). "Microcircuitry and function of the inferior olive." Trends Neurosci 21(9): 391-400.

Dho, S. H. and K. S. Kwon (2003). "The Ret finger protein induces apoptosis via its RING finger-B box-coiled-coil motif." J Biol Chem 13: 13. 


\section{References}

Diener, H. C. and J. Dichgans (1992). "Pathophysiology of cerebellar ataxia.” Mov Disord 7(2): 95-109.

El-Husseini, A. E., D. Kwasnicka, et al. (2000). "BERP, a novel ring finger protein, binds to alpha-actinin-4.” Biochem Biophys Res Commun 267(3): 906-11.

El-Husseini, A. E. and S. R. Vincent (1999). "Cloning and characterization of a novel RING finger protein that interacts with class V myosins." J Biol Chem 274(28): 19771-7.

Evans, L. L., A. J. Lee, et al. (1998). "Vesicle-associated brain myosin-V can be activated to catalyze actin-based transport.” J Cell Sci 111(Pt 14): 2055-66.

Evans, M. J. (1998). “Gene trapping--a preface.” Dev Dyn 212(2): 167-9.

Feddersen, R. M., R. Ehlenfeldt, et al. (1992). "Disrupted cerebellar cortical development and progressive degeneration of Purkinje cells in SV40 T antigen transgenic mice." Neuron 9(5): 955-66.

Fernandez-Gonzalez, A., A. R. La Spada, et al. (2002). "Purkinje cell degeneration (pcd) phenotypes caused by mutations in the axotomy-induced gene, Nna1." Science 295(5561): 1904-6.

Fletcher, C. F., C. M. Lutz, et al. (1996). "Absence epilepsy in tottering mutant mice is associated with calcium channel defects." Cell 87(4): 607-17.

Foury, F. and O. Cazzalini (1997). "Deletion of the yeast homologue of the human gene associated with Friedreich's ataxia elicits iron accumulation in mitochondria." FEBS Lett 411(2-3): 373-7.

Friedrich, G. and P. Soriano (1991). "Promoter traps in embryonic stem cells: a genetic screen to identify and mutate developmental genes in mice." Genes Dev 5(9): 1513-23.

Frohman, M. A., M. K. Dush, et al. (1988). "Rapid production of full-length cDNAs from rare transcripts: amplification using a single gene-specific oligonucleotide primer." Proc Natl Acad Sci U S A 85(23): 8998-9002.

Gibb, B. J., J. P. Brion, et al. (1998). "Neuropathological abnormalities in transgenic mice harbouring a phosphorylation mutant neurofilament transgene." J Neurochem 70(2): 492500 . 


\section{References}

Goddard, A. D., J. Borrow, et al. (1991). "Characterization of a zinc finger gene disrupted by the $t(15 ; 17)$ in acute promyelocytic leukemia.” Science 254(5036): 1371-4.

Gorlin, J. B., R. Yamin, et al. (1990). "Human endothelial actin-binding protein (ABP-280, nonmuscle filamin): a molecular leaf spring." J Cell Biol 111(3): 1089-105.

Grusser-Cornehls, U. and J. Baurle (2001). "Mutant mice as a model for cerebellar ataxia." Prog Neurobiol 63(5): 489-540.

Hanahan, D. (1983). "Studies on transformation of Escherichia coli with plasmids." J Mol Biol 166(4): 557-80.

Herrup, K. and B. Kuemerle (1997). "The compartmentalization of the cerebellum.” Annu Rev Neurosci 20: 61-90.

Hicke, L. (1999). "Gettin' down with ubiquitin: turning off cell-surface receptors, transporters and channels." Trends Cell Biol 9(3): 107-12.

Hicke, L. (2001). "Protein regulation by monoubiquitin.” Nat Rev Mol Cell Biol 2(3): 195201.

Hitotsumachi, S., D. A. Carpenter, et al. (1985). "Dose-repetition increases the mutagenic effectiveness of N-ethyl-N-nitrosourea in mouse spermatogonia." Proc Natl Acad Sci U S A 82(19): 6619-21.

Holland, K. D., A. C. McKeon, et al. (1992). "Relative anticonvulsant effects of GABAmimetic and GABA modulatory agents.” Epilepsia 33(6): 981-6.

Ito, M. (1982). "Cerebellar control of the vestibulo-ocular reflex--around the flocculus hypothesis.” Annu Rev Neurosci 5: 275-96.

Jackson, P. K., A. G. Eldridge, et al. (2000). "The lore of the RINGs: substrate recognition and catalysis by ubiquitin ligases." Trends Cell Biol 10(10): 429-39.

Joazeiro, C. A. and A. M. Weissman (2000). "RING finger proteins: mediators of ubiquitin ligase activity." Cell 102(5): 549-52. 


\section{References}

Kanno, M., M. Hasegawa, et al. (1995). "mel-18, a Polycomb group-related mammalian gene, encodes a transcriptional negative regulator with tumor suppressive activity." Embo J 14(22): $5672-8$.

Kano, M., K. Hashimoto, et al. (1997). "Persistent multiple climbing fiber innervation of cerebellar Purkinje cells in mice lacking mGluR1.” Neuron 18(1): 71-9.

Kano, M., K. Hashimoto, et al. (1998). "Phospholipase cbeta4 is specifically involved in climbing fiber synapse elimination in the developing cerebellum." Proc Natl Acad Sci U S A 95(26): 15724-9.

Klockgether, T. and B. Evert (1998). "Genes involved in hereditary ataxias." Trends Neurosci 21(9): 413-8.

Klockgether, T., U. Wullner, et al. (2000). "The molecular biology of the autosomal-dominant cerebellar ataxias." Mov Disord 15(4): 604-12.

Laird, P. W., A. Zijderveld, et al. (1991). "Simplified mammalian DNA isolation procedure." Nucleic Acids Res 19(15): 4293.

LaVail, M. M., J. C. Blanks, et al. (1982). "Retinal degeneration in the pcd cerebellar mutant mouse. I. Light microscopic and autoradiographic analysis." J Comp Neurol 212(3): 21730 .

Lavedan, C., S. Buchholtz, et al. (2002). "A mutation in the human neurofilament M gene in Parkinson's disease that suggests a role for the cytoskeleton in neuronal degeneration." Neurosci Lett 322(1): 57-61.

Leighton, P. A., K. J. Mitchell, et al. (2001). "Defining brain wiring patterns and mechanisms through gene trapping in mice." Nature 410(6825): 174-9.

Letts, V. A., R. Felix, et al. (1998). "The mouse stargazer gene encodes a neuronal Ca2+channel gamma subunit." Nat Genet 19(4): 340-7.

Lovering, R., I. M. Hanson, et al. (1993). "Identification and preliminary characterization of a protein motif related to the zinc finger." Proc Natl Acad Sci U S A 90(6): 2112-6.

Lynch, M., U. Sayin, et al. (2000). "Long-term consequences of early postnatal seizures on hippocampal learning and plasticity.” Eur J Neurosci 12(7): 2252-64. 


\section{References}

Mercer, J. A., P. K. Seperack, et al. (1991). "Novel myosin heavy chain encoded by murine dilute coat colour locus.” Nature 349(6311): 709-13.

Mersiyanova, I. V., A. V. Perepelov, et al. (2000). "A new variant of Charcot-Marie-Tooth disease type 2 is probably the result of a mutation in the neurofilament-light gene." Am J Hum Genet 67(1): 37-46.

Miki, Y., J. Swensen, et al. (1994). "A strong candidate for the breast and ovarian cancer susceptibility gene BRCA1.” Science 266(5182): 66-71.

Miyata, M., E. A. Finch, et al. (2000). "Local calcium release in dendritic spines required for long-term synaptic depression.” Neuron 28(1): 233-44.

Morimoto, K., K. Sato, et al. (1998). "Time-dependent changes in neurotrophic factor mRNA expression after kindling and long-term potentiation in rats." Brain Res Bull 45(6): 599-605.

Mullen, R. J., E. M. Eicher, et al. (1976). "Purkinje cell degeneration, a new neurological mutation in the mouse." Proc Natl Acad Sci U S A 73(1): 208-12.

Niikura, T., Y. Hashimoto, et al. (2003). "A tripartite motif protein TRIM11 binds and destabilizes Humanin, a neuroprotective peptide against Alzheimer's disease-relevant insults." Eur J Neurosci 17(6): 1150-8.

Niwa, H., K. Araki, et al. (1993). "An efficient gene-trap method using poly A trap vectors and characterization of gene-trap events." J Biochem (Tokyo) 113(3): 343-9.

Niwa, J., S. Ishigaki, et al. (2002). "Dorfin ubiquitylates mutant SOD1 and prevents mutant SOD1-mediated neurotoxicity.” J Biol Chem 277(39): 36793-8.

Norman, D. J., L. Feng, et al. (1995). "The lurcher gene induces apoptotic death in cerebellar Purkinje cells.” Development 121(4): 1183-93.

Ochman, H., A. S. Gerber, et al. (1988). "Genetic applications of an inverse polymerase chain reaction." Genetics 120(3): 621-3.

Ohkawa, N., K. Kokura, et al. (2001). "Molecular cloning and characterization of neural activity-related RING finger protein (NARF): a new member of the RBCC family is a candidate for the partner of myosin V." J Neurochem 78(1): 75-87. 


\section{References}

Olanow, C. W. and W. G. Tatton (1999). "Etiology and pathogenesis of Parkinson's disease.” Annu Rev Neurosci 22: 123-44.

Ophoff, R. A., G. M. Terwindt, et al. (1996). "Familial hemiplegic migraine and episodic ataxia type- 2 are caused by mutations in the Ca2+ channel gene CACNL1A4." Cell 87(3): 543-52.

Patil, N., D. R. Cox, et al. (1995). "A potassium channel mutation in weaver mice implicates membrane excitability in granule cell differentiation.” Nat Genet 11(2): 126-9.

Paulson, H. L., M. K. Perez, et al. (1997). "Intranuclear inclusions of expanded polyglutamine protein in spinocerebellar ataxia type 3." Neuron 19(2): 333-44.

Pires da Silva, A. F. (1999). Identification and characterization of genes involved in the control of mouse development by the gene trap metod, Georg-August-University Göttingen.

Pizoli, C. E., H. A. Jinnah, et al. (2002). "Abnormal cerebellar signaling induces dystonia in mice." J Neurosci 22(17): 7825-33.

Pozas, E., J. Ballabriga, et al. (1997). "Kainic acid-induced excitotoxicity is associated with a complex c-Fos and c-Jun response which does not preclude either cell death or survival." $\mathbf{J}$ Neurobiol 33(3): 232-46.

Rao, M. V., L. J. Engle, et al. (2002). "Myosin Va binding to neurofilaments is essential for correct myosin Va distribution and transport and neurofilament density." J Cell Biol 159(2): 279-90.

Reymond, A., G. Meroni, et al. (2001). "The tripartite motif family identifies cell compartments." Embo J 20(9): 2140-51.

Rezai, Z. and C. H. Yoon (1972). "Abnormal rate of granule cell migration in the cerebellum of "Weaver" mutant mice." Dev Biol 29(1): 17-26.

Robertson, J., J. Kriz, et al. (2002). "Pathways to motor neuron degeneration in transgenic mouse models." Biochimie 84(11): 1151-60.

Rupp, R. A., L. Snider, et al. (1994). "Xenopus embryos regulate the nuclear localization of XMyoD.” Genes Dev 8(11): 1311-23. 


\section{References}

Russell, L. B., P. R. Hunsicker, et al. (1989). "Chlorambucil effectively induces deletion mutations in mouse germ cells.” Proc Natl Acad Sci U S A 86(10): 3704-8.

Ruthrich, H., G. Grecksch, et al. (2001). "Development of long-lasting potentiation effects in the dentate gyrus during pentylenetetrazol kindling." Int J Dev Neurosci 19(3): 247-54.

Salminen, M., B. I. Meyer, et al. (2000). "Netrin 1 is required for semicircular canal formation in the mouse inner ear." Development 127(1): 13-22.

Salminen, M., B. I. Meyer, et al. (1998). "Efficient poly A trap approach allows the capture of genes specifically active in differentiated embryonic stem cells and in mouse embryos." Dev Dyn 212(2): 326-33.

Sambrook, J., E. F. Fritsch, et al. (1989). Molecular Cloning: A laboratory manual, Cold Spring Harbour Laboratory Press.

Saurin, A. J., K. L. Borden, et al. (1996). "Does this have a familiar RING?" Trends Biochem Sci 21(6): 208-14.

Schauwecker, P. E., J. J. Ramirez, et al. (2000). "Genetic dissection of the signals that induce synaptic reorganization.” Exp Neurol 161(1): 139-52.

Schultz, J., R. R. Copley, et al. (2000). "SMART: a web-based tool for the study of genetically mobile domains.” Nucleic Acids Res 28(1): 231-4.

Schultz, J., F. Milpetz, et al. (1998). "SMART, a simple modular architecture research tool: identification of signaling domains." Proc Natl Acad Sci U S A 95(11): 5857-64.

Shepherd, G. M. (1998). The Synaptic Organization of the Brain, Oxford University Press.

Shimura, H., N. Hattori, et al. (2000). "Familial Parkinson disease gene product, parkin, is a ubiquitin-protein ligase." Nat Genet 25(3): 302-5.

Slack, F. J. and G. Ruvkun (1998). "A novel repeat domain that is often associated with RING finger and B-box motifs.” Trends Biochem Sci 23(12): 474-5.

Smart, S. L., V. Lopantsev, et al. (1998). "Deletion of the K(V)1.1 potassium channel causes epilepsy in mice.” Neuron 20(4): 809-19. 


\section{References}

Smeyne, R. J., T. Chu, et al. (1995). "Local control of granule cell generation by cerebellar Purkinje cells.” Mol Cell Neurosci 6(3): 230-51.

Smeyne, R. J. and D. Goldowitz (1989). "Development and death of external granular layer cells in the weaver mouse cerebellum: a quantitative study." J Neurosci 9(5): 1608-20.

Stanford, W. L., J. B. Cohn, et al. (2001). "Gene-trap mutagenesis: past, present and beyond." Nat Rev Genet 2(10): 756-68.

Staub, O., I. Gautschi, et al. (1997). "Regulation of stability and function of the epithelial $\mathrm{Na}+$ channel $(\mathrm{ENaC})$ by ubiquitination.” Embo J 16(21): 6325-36.

Stoykova, A., K. Chowdhury, et al. (1998). "Gene trap expression and mutational analysis for genes involved in the development of the mammalian nervous system." Dev Dyn 212(2): 198-213.

Strous, G. J., P. van Kerkhof, et al. (1996). "The ubiquitin conjugation system is required for ligand-induced endocytosis and degradation of the growth hormone receptor." Embo J 15(15): 3806-12.

Tabb, J. S., B. J. Molyneaux, et al. (1998). "Transport of ER vesicles on actin filaments in neurons by myosin V.” J Cell Sci 111(Pt 21): 3221-34.

Takagishi, Y., S. Oda, et al. (1996). "The dilute-lethal (dl) gene attacks a Ca2+ store in the dendritic spine of Purkinje cells in mice.” Neurosci Lett 215(3): 169-72.

Thomas, K. R. and M. R. Capecchi (1987). "Site-directed mutagenesis by gene targeting in mouse embryo-derived stem cells." Cell 51(3): 503-12.

Thompson, J. D., D. G. Higgins, et al. (1994). "CLUSTAL W: improving the sensitivity of progressive multiple sequence alignment through sequence weighting, position-specific gap penalties and weight matrix choice.” Nucleic Acids Res 22(22): 4673-80.

Toniato, E., X. P. Chen, et al. (2002). "TRIM8/GERP RING finger protein interacts with SOCS-1.” J Biol Chem 277(40): 37315-22.

Tyers, M. and P. Jorgensen (2000). "Proteolysis and the cell cycle: with this RING I do thee destroy." Curr Opin Genet Dev 10(1): 54-64. 


\section{References}

Voss, A. K., T. Thomas, et al. (1998). "Efficiency assessment of the gene trap approach." Dev Dyn 212(2): 171-80.

Weber, F., J. de Villiers, et al. (1984). "An SV40 "enhancer trap" incorporates exogenous enhancers or generates enhancers from its own sequences." Cell 36(4): 983-92.

Wehr, R., A. Mansouri, et al. (1997). "Fkh5-deficient mice show dysgenesis in the caudal midbrain and hypothalamic mammillary body." Development 124(22): 4447-56.

Weissman, A. M. (2001). "Themes and variations on ubiquitylation.” Nat Rev Mol Cell Biol 2(3): 169-78.

Welsh, J. P., E. J. Lang, et al. (1995). "Dynamic organization of motor control within the olivocerebellar system.” Nature 374(6521): 453-7.

Wiles, M. V., F. Vauti, et al. (2000). "Establishment of a gene-trap sequence tag library to generate mutant mice from embryonic stem cells." Nat Genet 24(1): 13-4.

Williams, P. L., R. Warwick, et al. (1989). Gray's anatomy, Churchill livingstone.

Wilson, S. M., B. Bhattacharyya, et al. (2002). "Synaptic defects in ataxia mice result from a mutation in Usp14, encoding a ubiquitin-specific protease." Nat Genet 32(3): 420-5.

Wu, X., B. Bowers, et al. (1998). "Visualization of melanosome dynamics within wild-type and dilute melanocytes suggests a paradigm for myosin $\mathrm{V}$ function In vivo." J Cell Biol 143(7): 1899-918.

Xiong, J. W., R. Battaglino, et al. (1998). "Large-scale screening for developmental genes in embryonic stem cells and embryoid bodies using retroviral entrapment vectors." Dev Dyn 212(2): 181-97.

Xu, L., L. Yang, et al. (2003). "BTBD1 and BTBD2 colocalize to cytoplasmic bodies with the RBCC/tripartite motif protein, TRIM5delta.” Exp Cell Res 288(1): 84-93.

Zanjani, H. S., M. W. Vogel, et al. (1996). "Increased cerebellar Purkinje cell numbers in mice overexpressing a human bcl-2 transgene.” J Comp Neurol 374(3): 332-41. 


\section{References}

Zhang, L. and J. E. Goldman (1996). "Generation of cerebellar interneurons from dividing progenitors in white matter.” Neuron 16(1): 47-54.

Zhuchenko, O., J. Bailey, et al. (1997). "Autosomal dominant cerebellar ataxia (SCA6) associated with small polyglutamine expansions in the alpha 1A-voltage-dependent calcium channel." Nat Genet 15(1): 62-9.

Zuo, J., P. L. De Jager, et al. (1997). "Neurodegeneration in Lurcher mice caused by mutation in delta2 glutamate receptor gene.” Nature 388(6644): 769-73. 


\section{Acknowladgements:}

\subsection{Acknowladgements:}

In the first place I would like to thank my supervisor Prof. Dr. Peter Gruss for giving me the opportunity to work in his laboratory, encouragement for my work and constant and generous support of my project.

Special thanks I owe to Dr. Gonzalo Alvarez-Bolado for introducing me to the field of neuroscience, many suggestions concerning my project, and correction of my $\mathrm{PhD}$ thesis.

I also have to thank to Dr. Francesco Ferraguti for helping me with electron microscopy, to Dr. Paul Bridgman for sending me myosin V polyclonal antibodies, Marianne Schuster and Anja Dietrich for making my stay in Göttingen much, much easier, to Dr. Anastasia Stoykova for sharing many protocols with me, Reiner Libal and Urike Teichman for taking care of the mouse colony, to Dr. Jana Schmitzova and Dr. Xiaopin Yang for helping me with yeast two-hybrid screening.

I am very grateful to many friends from the International Neuroscience and Molecular biology $\mathrm{PhD}$ programs. It was my pleasure to spend my time with you. 


\title{
Curriculum Vitae
}

\subsection{Curriculum Vitae}

\author{
Name: $\quad$ Martin Balastik \\ Date of birth: 30.6 .1975 \\ Place of birth: Brno, Czech Republic \\ Nationality: Czech
}

\section{Education:}

1981-1989 Primary school, Brno

1989-1993 High school, Brno

1993 - 1996 Bachelors degree in Molecular biology, Faculty of Natural Sciences, Masaryk University, Brno

1996 - 1998 Masters degree in Molecular Biology, Charles University, Prague Masters work done in the Academy of Sciences of the Czech republic, in the lab. of Prof. Dr. Jan Svoboda.

Topic: Insertion of Sp1 binding sites into regulatory element U3 LTR of Rouse sarcoma virus affects proviral expression in nonpermissinve mammalian cells

1999 - 2003 Max Planck Institute for Biophysical Chemistry, Göttingen

$\mathrm{PhD}$ in the Department of Molecular Cell Biology, under supervision of Prof. Dr. Peter Gruss

Topic: Trim2 mutant mice as a model for cerebellar ataxia

\section{Publications:}

Balastik M., Ferraguti F., Pires-DaSilva A., Alvarez-Bolado G., Gruss P. Mutation in RING finger protein TRIM2 leads to progressive degeneration of cerebellar and retinal neurons (in preparation) 